GABRIELA COREZZI WERNECK

PRODUÇÃO DE PROTEASES POR FUNGOS ENDOFÍTICOS ISOLADOS DE PLANTAS DO CERRADO

BRASÍLIA, 2016 
UNIVERSIDADE DE BRASÍLIA

FACULDADE DE CIÊNCIAS DA SAÚDE

PROGRAMA DE PÓS-GRADUAÇÃO EM CIÊNCIAS DA SAÚDE

GABRIELA COREZZI WERNECK

\section{PRODUÇÃO DE PROTEASES POR FUNGOS ENDOFÍTICOS ISOLADOS DE PLANTAS DO CERRADO}

Dissertação apresentada como requisito parcial para a obtenção do Título de Mestre em Ciências da Saúde pelo Programa de PósGraduação em Ciências da Saúde da Universidade de Brasília.

Orientador: Profa. Dra. Pérola de Oliveira Magalhães Dias Batista 


\section{PRODUÇÃO DE PROTEASES POR FUNGOS ENDOFÍTICOS ISOLADOS DE PLANTAS DO CERRADO}

Dissertação apresentada como requisito parcial para a obtenção do Título de Mestre em Ciências da Saúde pelo Programa de Pós-Graduação em Ciências da Saúde da Universidade de Brasília.

Aprovada em 30 de agosto de 2016

BANCA EXAMINADORA

Profa. Dra. Pérola de Oliveira Magalhães Dias Batista

Universidade de Brasília (UnB)

Profa. Dra. Maria de Fátima Borin

Universidade de Brasília (UnB)

Prof. Dr. Edivaldo Ximenes Ferreira Filho

Universidade de Brasília (UnB) 


\section{AGRADECIMENTOS}

Agradeço em primeiro lugar aos meus familiares, em especial aos meus pais Aracy e Sérgio e meus tios Aline e Armando pelo carinho, apoio e compreensão dedicados a mim durante o mestrado.

Agradeço á prof. Dra. Pérola de Oliveira Magalhães pela confiança, orientação e ensinamentos não só durante a realização deste trabalho, como também, em outros projetos que realizei sob sua orientação durante a graduação.

Ao Vini pelo companheirismo, amor e compreensão. Obrigada por apoiar minhas escolhas!

Aos amigos do laboratório pelos ensinamentos, momentos de descontração e incentivo.

Ao departamento de ciências da saúde da UnB pela oportunidade de realizar esta pesquisa, área pela qual sou apaixonada.

Aos professores, técnicos e colegas do Laboratório de produtos naturais, laboratório de controle de qualidade de medicamentos e demais laboratórios que cooperaram para a realização dessa dissertação. Obrigada pelos ensinamentos, auxílio e atenção.

À CAPES pelo apoio financiando a bolsa de mestrado.

À FAPDF pelo auxilio financeiro através do Edital MCT/CNPq/FNDCT/FAPs/MEC/CAPES/PRO-CENTRO-OESTE №031/2010, processo numero 193.000.484/2011.

AO CNPq pelo auxilio financeiro através do Edital MCT/CNPq/FNDCT/FAPs/MEC/CAPES/PRO-CENTRO-OESTE №031/2010, processo numero 564208/2010-8. 
"Seja a mudança que você deseja ver no mundo."

\section{Mahatma Gandhi}

"You got to gather up what you need

You got to choose a direction And when the moment is right for you You got to go" 


\section{RESUMO}

Proteases são enzimas, que catalisam a hidrolise das ligações peptídicas. Estas enzimas são aplicadas em diversas indústrias como a alimentícia, farmacêutica, cosmética, de couro e de detergente. São produzidas por animais, plantas e microrganismos. Entre seus produtores encontram-se os fungos endofíticos, que são microrganismos que vivem no interior de plantas de forma simbiótica. Sabendo disso, o objetivo principal deste trabalho foi isolar fungos endofíticos de plantas do cerrado, avalia-los quanto á produção de proteases extracelulares, visando aplicação industrial. Foram isolados 58 fungos de 13 espécies de plantas endêmicas do cerrado. Primeiramente, foi realizada uma triagem para avaliar quais fungos eram produtores de protease, 36 fungos demonstraram halo indicando produção de protease em meio de cultura ágar-leite. Foi realizado ensaio enzimático utilizando azocaseína $0,5 \%$ como substrato para avaliar quantitativamente a produção de proteases. Os produtores que demonstraram maior atividade de protease foram os fungos endofíticos codificados como BR, OH03, PT02, PEQ03 e KC01. O fungo BR, apresentou $41 \mathrm{Ul} / \mathrm{mL}$ de atividade proteolítica, $\mathrm{pH}$ ótimo 7,0 e temperatura ótima de $60^{\circ} \mathrm{C}$ e foi escolhido para dar continuidade ao trabalho. Visando a otimização da produção de protease foram testados meios com diferentes fontes de nitrogênio e carbono, a maior produção de proteases ocorreu no meio contendo peptona, extrato de levedura e glicose. A curva de crescimento mostrou que o melhor dia de produção da enzima foi $09^{\circ}$ dia. A protease foi parcialmente purificada utilizando cromatografia de troca iônica. A fração parcialmente purificada foi caracterizada com atividade ótima em pH 7,0 e $60^{\circ} \mathrm{C}$ e manteve $100 \%$ desta atividade a $60^{\circ} \mathrm{C}$ por 1 hora. A enzima foi testada como removedor de manchas para a indústria de detergentes melhorando a remoção de manchas quando adicionada a um detergente comercial e demonstrou ser compatível com marcas de detergente para roupas comerciais.

Palavras-chave: Proteases; Fungos endofíticos; Fungo filamentoso; Fermentação submersa. 


\begin{abstract}
Proteases are enzymes which catalyze the hydrolysis of peptides bonds. These enzymes are applied in various industries such as food, pharmaceutical, cosmetics, leather and detergent. They are produced by animals, plants and microorganisms. Among its producers are the endophytic fungi, which are microorganisms that live inside plants symbiotically. Thus, the aim of this study was to isolate endophytic fungi of the Cerrado biome plants and evaluate the production of extracellular proteases for an industrial application. It was isolated 58 endophytic fungi from 13 different species of endemic plants. First, a screening was performed to evaluate fungi protease producing. 36 fungi has shown halo production using milk agar culture. Enzyme assay was performed using azocasein $0.5 \%$ as substrate to evaluate quantitatively the production of proteases. The best producers were endophytes encoded as BR, OH03, PT02, PEQ03 and KC01. Since then BR fungus stood out among them. BR showed $41 \mathrm{IU} / \mathrm{mL}$ of proteolytic activity, optimum $\mathrm{pH} 7.0$ and optimum temperature of $60{ }^{\circ} \mathrm{C}$ and was chosen. To optimize protease production the medium were tested with different carbon and nitrogen sources. The best production of proteases occurred in a medium containing peptone, yeast extract and glucose. The best day of the enzyme production, based on growth curve curve, was the 9th day. The protease was partially purified using ion exchange chromatography. The partially purified fraction was characterized and showed highest activity at $\mathrm{pH} 7.0,60{ }^{\circ} \mathrm{C}$ and maintained $100 \%$ stability at $60{ }^{\circ} \mathrm{C}$ for 1 hour. The enzyme was tested as stain remover detergent industry to improve the spot removal. When added to a commercial detergent, the enzyme demonstrated to be compatible with commercial brands of detergent clothes.
\end{abstract}

Keywords: Proteases; Endophytic fungi; Filamentous fungus; Submerged fermentation 


\section{LISTA DE FIGURAS}

Figura 1 Representação de hidrólise proteica catalisada por protease (LIMA e colaboradores, 2008) 15

Figura 2. Placa-teste demostrando o isolamento de fungos endofíticos crescidos a partir de folha de Eriotheca pubescens. Foto tirada após 48 horas de encubação da placa em estufa a $28^{\circ} \mathrm{C}$.

Figura 3. Esquema da composição dos meios de cultivo para avaliar melhor fonte de nitrogênio.

Figura 4. Equações utilizadas para cálculo dos parâmetros cinéticos: velocidade específica de crescimento ( $\mu$ máx), produtividade específica em enzima $\left(Y_{E m a ́ x}\right)$ e fator de conversão de biomassa em enzima $\left(\mathrm{Y}_{E / X}\right)$.

Figura 5. Fluxograma do processo de purificação de proteases presentes no extrato bruto após cultivo em meio liquido por 7 dias a $28^{\circ} \mathrm{C}$ e $120 \mathrm{rpm}$.

Figura 6. Fungos endofíticos isolados de folhas de plantas do cerrado após assepsia da superfície com hipoclorito de sódio $2 \%$, álcool $70 \%$ e água.

Figura 7. Halos produzidos pelos fungos endofíticos PT01B, KC02, BR, DM02, OH04, KC01, SSL01, OH05, DM01, PEQ10, PEQ12, PT01P, OH02, PEQ04, PEQ05, PEQ01, PEQ08 E SKL01, respectivamente.

Figura 8. Atividade proteolítica de fungos endofíticos isolados de folhas do cerrado brasileiro. As barras de erro correspondem a um intervalo de confiança de $95 \%$ nos valores obtidos.

Figura 9. Cinco fungos produtores de protease selecionados neste trabalho: KC01, PT02, BR, OH03 e PEQ03

Figura 10. Efeito do $\mathrm{pH}$ na atividade proteolítica dos fungos endofíticos $\mathrm{BR}, \mathrm{OH} 03$, PEQ03, KC01 e PT02 a 55 C.

Figura 11. Efeito da temperatura na atividade proteolítica dos fungos endofíticos $B R$, $\mathrm{OH03}, \mathrm{PEQ} 03, \mathrm{KC01}$ e PT02. As temperaturas de incubação variaram de $30^{\circ} \mathrm{C}$ a $80^{\circ} \mathrm{C}$. para os fungos $\mathrm{OH} 03, \mathrm{PEQ} 03, \mathrm{KC} 01$ e PT02 foi de $50^{\circ} \mathrm{C}$, e para o fungo $\mathrm{BR}$ foi de $60^{\circ} \mathrm{C}$ 
Figura 12. Fungo BR crescido em placa de Petri contendo meio Sabouraud-Dextrose (Himedia)

Figura 13. Produção de protease pelo fungo BR em diferentes fontes de nitrogênio: meio mínimo e peptona (MMP); meio mínimo e extrato de levedura ( $M M L)$; meio mínimo, peptona e extrato de levedura (MMPL); meio mínimo, peptona, extrato de levedura e glicose (MMPLG). Condições de cultivo: $28^{\circ} \mathrm{C}, 120 \mathrm{rpm}, 7$ dias. As barras de erro representam $95 \%$ dos limites de confiança para os resultados obtidos.

Figura 14. (A) Biomassa $(\bullet)$ e $\mathrm{pH}(\boldsymbol{\Delta})$ em meio MMPLG durante cultivo submerso a $28^{\circ} \mathrm{C}$ a $120 \mathrm{rpm}$. (B) Atividade enzimática (•) e glicose $(\boldsymbol{\Delta})$ em meio de cultivo MMPLG.

Figura 15. Cromatograma da purificação de protease utilizando cromatografia em coluna de troca iônica DEAE FF, mostrando atividade enzimática $(\boldsymbol{\Delta})$, proteína $(\bullet)$ e gradiente de $\mathrm{NaCl}(-)$. A amostra foi eluída com tampão fosfato de sódio $0,1 \mathrm{M} \mathrm{pH}$ 7,0, com fluxo de 0,300 mL/min. Foi utilizado tampão fosfato de sódio 0,1 M pH 7,0 contendo $1 \mathrm{M}$ de $\mathrm{NaCl}$ em gradiente linear para desligar as proteínas da coluna. Equipamento utilizado: AKTA Pure system (GE healthcare biosciences, uppsala, Suíça)

Figura 16. (A) Eletroforese em gel de poliacrilamida. PD - Marcadores de peso molecular (97 - 14,4 kDa, GE Lifesciences). EB - Extrato bruto do fungo endofítico BR. DEAE - Amostra semi--purificada em coluna de troca aniônica DEAE FF. (B) Zimograma em gel de poliacrilamida contendo $0,2 \%$ de gelatina como substrato. ...66 Figura 17. Avaliação do pH ótimo para a enzima semipurificada. $E$ ensaio foi realizado nos valores de $\mathrm{pH} 5,0$ a 9,0, e o pH ótimo foi 7,0, quando avaliada a atividade proteolítica da amostra.

Figura 18. Avaliação da melhor temperatura para atividade enzimática de protease. $\mathrm{O}$ ensaio foi realizado em temperaturas de $40^{\circ} \mathrm{C}$ a $80^{\circ} \mathrm{C}$ e a temperatura otima foi de $60^{\circ} \mathrm{C}$

Figura 19. Estabilidade térmica da enzima realizada a $50^{\circ} \mathrm{C}$ e pH 7,0 ..... .70

Figura 20. Tecidos de algodão manchados com molho de tomate, suco de couve, sangue de carne bovina e café. As machas foram fixadas com clorofórmio $2 \%$ e lavadas em agua corrente antes do ensaio. A segunda fileira mostra os tecidos lavados a $50^{\circ} \mathrm{C}$, em shaker com rotação de $150 \mathrm{rpm}$ contendo $25 \mathrm{~mL}$ de detergente em concentração de $7 \mathrm{~g} / \mathrm{L}$. A terceira fileira mostra os tecidos lavados com $20 \mathrm{~mL}$ de solução de detergente $+5 \mathrm{~mL}$ de solução enzimática 
Figura 21. Tecidos de algodão manchados com sangue de carne bovina. As machas foram fixadas com clorofórmio $2 \%$ e lavadas em agua corrente antes do ensaio. $O$ segundo tecido foi lavado a $50^{\circ} \mathrm{C}$, em shaker com rotação de $150 \mathrm{rpm}$ contendo 25 $\mathrm{mL}$ de detergente em concentração de $7 \mathrm{~g} / \mathrm{L}$. O terceiro tecido foi lavado com $20 \mathrm{~mL}$ de solução de detergente $+5 \mathrm{~mL}$ de solução enzimática somipurificada..................72 Figura 22. Compatibilidade da protease produzida pelo fungo BR com detergentes de marcas comerciais (M1, M2 e M3) a $50^{\circ} \mathrm{C}$ por 1 hora. As barras de erro representam $95 \%$ dos limites de confiança para os resultados obtidos .73 


\section{LISTA DE TABELAS}

Tabela 1 Classificação de algumas proteases segundo a base de dados MEROPS, incluindo família, subfamília, tipo de enzima e clã.................................................16 Tabela 2 produção de enzimas por fungos endofíticos e as plantas de que foram isolados (Borges e colaboradores, 2009) ......................................................... Tabela 3. Nome científico das plantas utilizadas no isolamento de fungos endofíticos.

Tabela 4 - Códigos atribuídos aos fungos endofíticos isolados e suas espécies hospedeiras.. 48

Tabela 5 - Códigos dos fungos endofíticos capazes de formar halo em meio sólido contendo ágar-leite sugestivo da produção de proteases.

Tabela 6. Parâmetros cinéticos principais da produção de enzima pelo fungo endofítico BR em meio MMPLG, $28^{\circ} \mathrm{C}, 120 \mathrm{rpm}$. .64

Tabela 7. Purificação da protease produzida pelo fungo endofítico $B R$ .65 


\section{LISTA DE SIGLAS E ABREVIATURAS}

$\begin{array}{ll}\text { TCA } & \text { Ácido Tricloroacético } \\ \text { VC } & \text { Volume de coluna } \\ \text { MMP } & \text { Meio líquido contendo meio mínimo e peptona } \\ \text { MML } & \text { Meio líquido contendo meio mínimo e extrato de levedura } \\ \text { MMPL } & \begin{array}{l}\text { Meio líquido contendo meio mínimo, peptona e estrato de } \\ \text { levedura }\end{array} \\ \text { MMPLG } & \begin{array}{l}\text { Meio líquido contendo meio mínimo, peptona, extrato de levedura e } \\ \text { glicose }\end{array} \\ \text { P } & \text { Peptona } \\ \text { TEMED } & \text { Tetrametilenodiamina } \\ \text { L } & \text { Extrato de levedura } \\ \text { T } & \text { Temperatura } \\ \text { SDS } & \text { Dodecil sulfato de sódio } \\ \text { BSA } & \text { Soro de albumina bovina } \\ \text { MM } & \text { Massa molecular } \\ \mu_{\text {máx }} & \text { Velocidade específica de crescimento } \\ Y_{E, m a ́ x} & \text { Produtividade específica em enzima } \\ Y_{E / X} & \text { Fator de conversão de biomassa em enzima }\end{array}$




\section{SUMÁRIO}

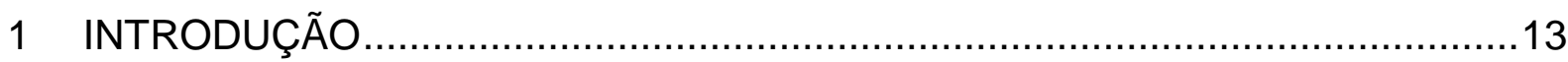

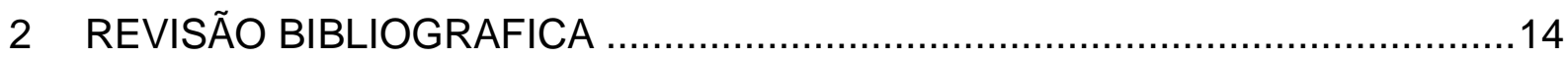

2.1 proteases e suas aplicações industriais ..................................................14

2.1.1 proteases e a indústria alimentícia .................................................18

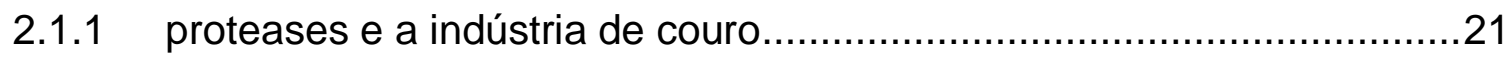

2.1.2 proteases e a indústria de detergente …………………………....22

2.1.3 Proteases e a indústria cosmética e farmacêutica.................................24

2.2 FUNGOS PRODUTORES DE PROTEASES …...................................27

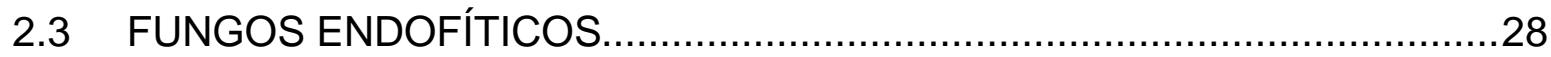

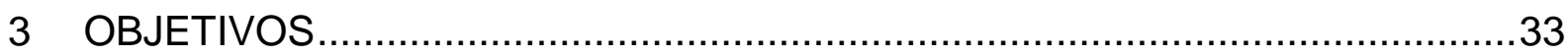

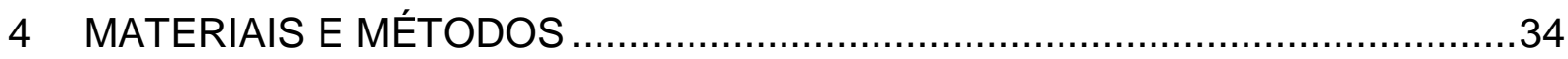

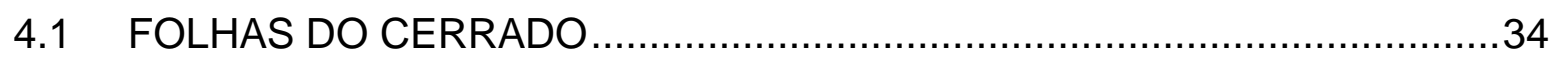

4.2 ISOLAMENTO DE FUNGOS ENDOFÍTICOS …............................................35

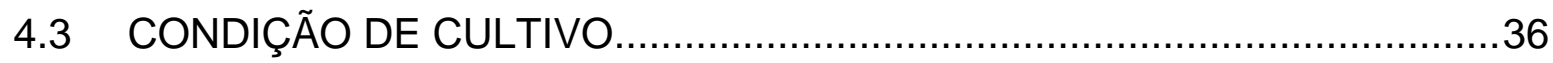

4.4 AVALIAÇÃO QUALITATIVA DA PRODUÇÃO DE PROTEASE ....................36

4.5 AVALIAÇÃO QUANTITATIVA DA PRODUÇÃO DE PROTEASE - ENSAIO

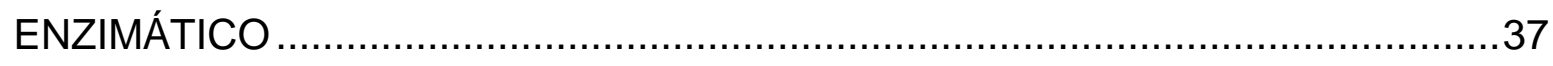

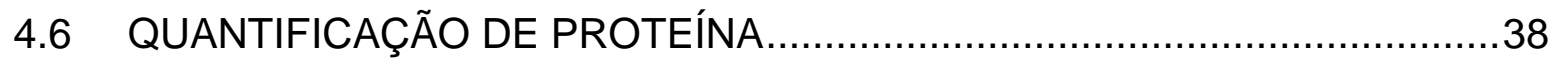

4.7 EFEITO DO PH NA ATIVIDADE PROTEOLÍTICA .......................................38

4.8 EFEITO DA TEMPERATURA NA ATIVIDADE PROTEOLÍTICA .................39

4.9 ESTUDO DO MELHOR MEIO DE CULTIVO PARA PRODUÇÃO

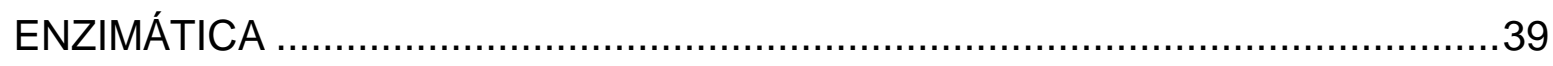

4.10 CURVA DE CRESCIMENTO E PARÂMETROS CINÉTICOS......................40 
4.11 PURIFICAÇÃO DA PROTEASE EXPRESSA PELO FUNGO ENDOFÍTICO

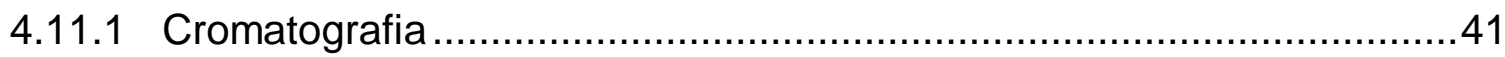

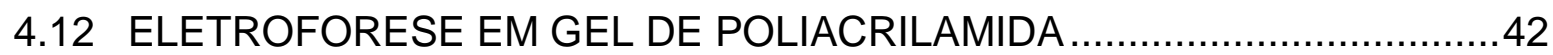

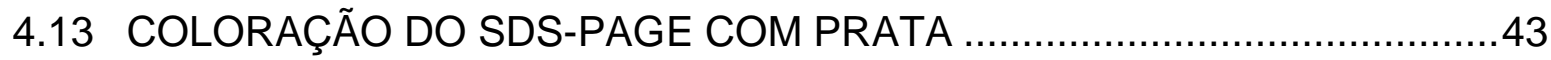

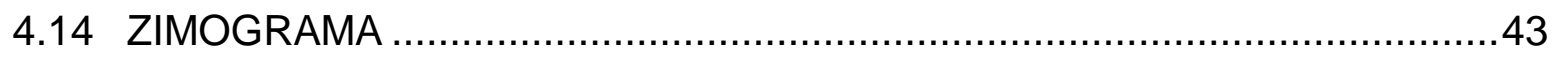

4.15 CARACTERIZAÇÃO PARCIAL DA ENZIMA PARCIALMENTE PURIFICADA 44

4.15.1 Avaliação do $\mathrm{pH}$ ótimo para atividade proteolítica ..............................44

4.15.2 Avaliação da temperatura ótima para atividade proteolítica .................44

4.15.3 Determinação da estabilidade térmica..........................................44

4.16 TRIAGEM PARA APLICAÇÃO ENZIMÁTICA DA PROTEASE $\ldots \ldots \ldots \ldots \ldots \ldots . . . . . . . .45$

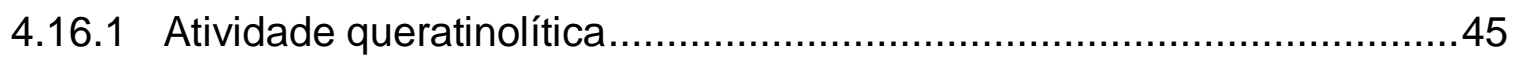

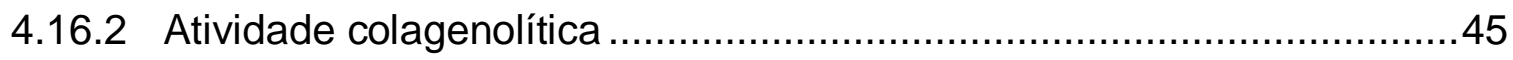

4.16.3 Atividade coagulante no leite ...............................................46

4.16.4 Atividade como removedor de manchas .........................................46

4.16.5 Compatibilidade com detergentes comerciais ................................47

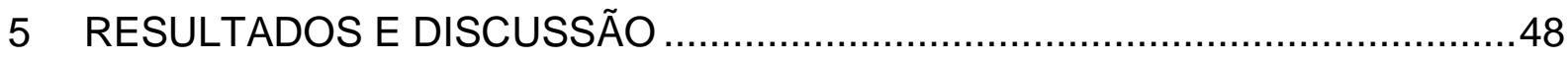

5.1 ISOLAMENTO DE FUNGOS ENDOFÍTICOS ...................................48

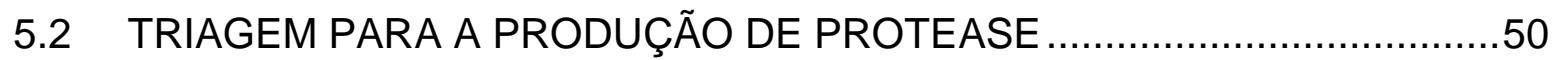

5.2.1 Avaliação qualitativa da produção de protease ................................50

5.2.2 Avaliação quantitativa da produção de protease .............................52

5.3 AVALIAÇÃO DA INFLUENCIA DO PH NA ATIVIDADE ENZIMATICA ........54

5.4 AVALIAÇÃO DA INFLUENCIA DA TEMPERATURA NA ATIVIDADE

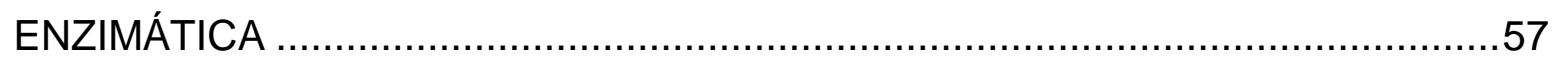

5.5 AVALIAÇÃO DA INFLUENCIA DA FONTE DE NITROGENIO NA

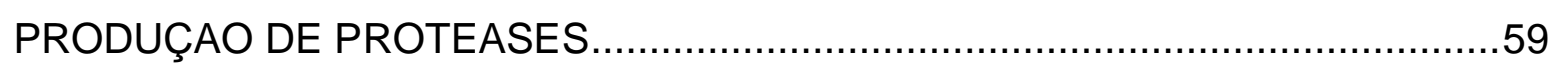

5.6 CURVA DE CRESCIMETO E PARÂMETROS CINÉTICOS .......................62 


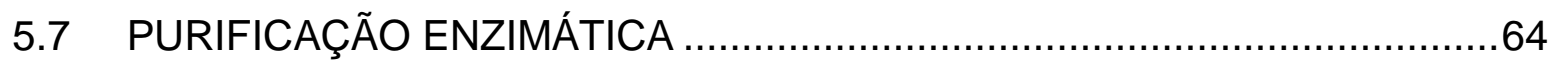

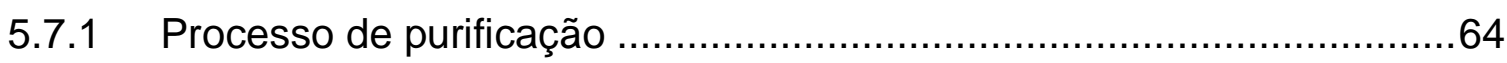

- Cromatografia em coluna de troca iônica Hitrap DEAE FF ........................64

5.8 CARACTERIZAÇÃO DA ENZIMA SEMIPURIFICADA ............................67

5.8.1 Avaliação do $\mathrm{pH}$ na atividade proteolítica............................................67

5.8.2 Avaliação da temperatura na atividade proteolítica ................................68

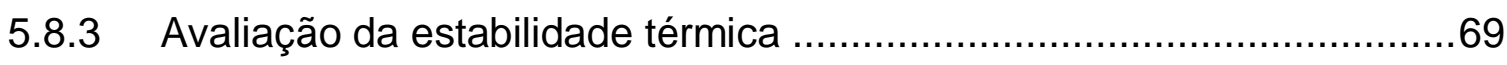

5.9 TRIAGEM PARA APLICAÇÃO ENZIMÁTICA DA PROTEASE ....................70

5.9.1 Compatibilidade com detergentes ...................................................72

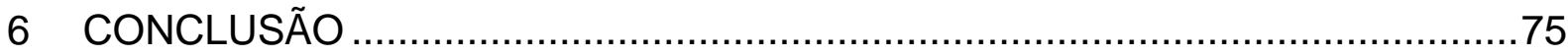

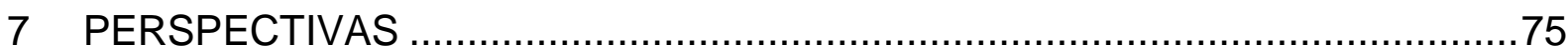

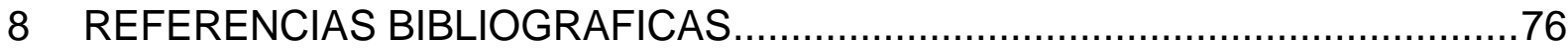




\section{INTRODUÇÃO}

Proteínas são polímeros que compreendem uma sequência contendo dezenas ou centenas de aminoácidos ligados entre si por ligações peptídicas. As proteínas possuem papel fundamental em diversos processos em seres vivos, pois desempenham funções como catálise enzimática, proteção imunológica, produção e transmissão de impulsos do sistema nervoso e controle do crescimento e diferenciação celular. Uma importante função das proteínas é a atividade como enzimas ou catalizadores biológicos $(1,2)$.

Os microrganismos são uma das principais fontes de enzimas industriais. Estas enzimas são bastante atrativas, pois os microrganismos podem ser cultivados facilmente, seus metabólitos podem ser obtidos em grandes quantidades e em tempo relativamente curto, além disso, a produção enzimática microbiana não está condicionada a questões sazonais e nem geográficas e é possível a utilização de matéria prima de baixo custo (3).

Dentre as enzimas industriais, $75 \%$ pertencem ao grupo das hidrolases e destas, dois terços são proteases, um dos grupos industrialmente mais importantes de enzimas $(4,5)$. As proteases são um grande grupo enzimático que possui aplicação em diversas indústrias (6), estas enzimas catalisam a clivagem de ligações peptídicas, portanto, as proteases são enzimas que catalisam a hidrólise de proteínas (7). A relevância deste grupo de enzimas, rica em diversidade estrutural e mecanismos de ação, se reflete na importância de suas aplicações em processos industriais (5).

Proteases podem ser produzidas por plantas, animais e microrganismos. A utilização de plantas como fonte de proteases é governada por vários fatores e é um processo que consome tempo, a produção de proteases por animais é difícil, pois envolve questões relacionadas ao abate de animais. Por esses motivos proteases de origem animal e vegetal não são capazes de atender as necessidades industriais desta, por isso há grande interesse pelas proteases de origem microbiana (7). 
São muitas as possíveis aplicações das enzimas proteolíticas. É comum a utilização destas em diversas indústrias tais como de alimentos (8-10), detergente $(11,12)$, couro (13), farmacêutica e de cosméticos (14) (15).

Microrganismos endofíticos vivem no interior do tecido de plantas de forma simbiótica, sem causar males a esta. Os endófitos, como podem ser chamados, mantém estreita relação com a planta e podem contribuir para sua sobrevivência, produzindo uma infinidade de substâncias que lhe oferecem proteção (16), dentre estes microrganismos estão os fungos endofíticos. Os produtos naturais produzidos pelos fungos endofíticos, uma vez isolados e caracterizados, possuem ampla aplicação industrial e biotecnológica. Já foram identificados fungos endofíticos produtores de antibióticos, imunossupressores, anticancerígenos, além de produtores de enzimas e outros metabólitos primários e secundários (16-18), dentre as enzimas produzidas por fungos endofíticos estão as enzimas proteolíticas.

Sabe-se que a formação de metabólitos acontece através da necessidade do organismo exercer alguma função específica no seu habitat (18), isso torna os fungos endofíticos uma fonte extremamente importante de produção de metabólitos, pois estes abrigam um habitat ainda pouco conhecido: o interior dos tecidos das plantas, o que pode leva-los à necessidade de produzir metabolitos novos e completamente diferentes dos já estudados.

Nesse sentido, o isolamento de fungos endofíticos e a identificação da produção de proteases por estes, e ainda, o estudo das características desta protease e identificação de uma provável aplicação industrial agrega conhecimentos sobre este assunto que ainda possui muitos espaços a se estudar.

\section{REVISÃO BIBLIOGRAFICA}

\subsection{PROTEASES E SUAS APLICAÇÕES INDUSTRIAIS}

Proteases constituem um grupo de enzimas cuja função catalítica é hidrolisar ligações peptídicas (Figura 1) (1, 19, 20).

As proteases (também denominadas peptidases, proteinases e enzimas proteolíticas) são classificadas como peptídeo hidrolases ou peptidases (EC 3.4) (7, 
21). A classificação mais atual destas enzimas, encontrada na base de dados MEROPS (22), é hierárquica, fundamentada na estrutura das proteases. Nesta, cada protease é atribuída a uma família com base em semelhanças estatisticamente significativas na sequência de aminoácidos, e as famílias homólogas são agrupadas em conjuntos que são denominados "clãs" $(21,23)$.
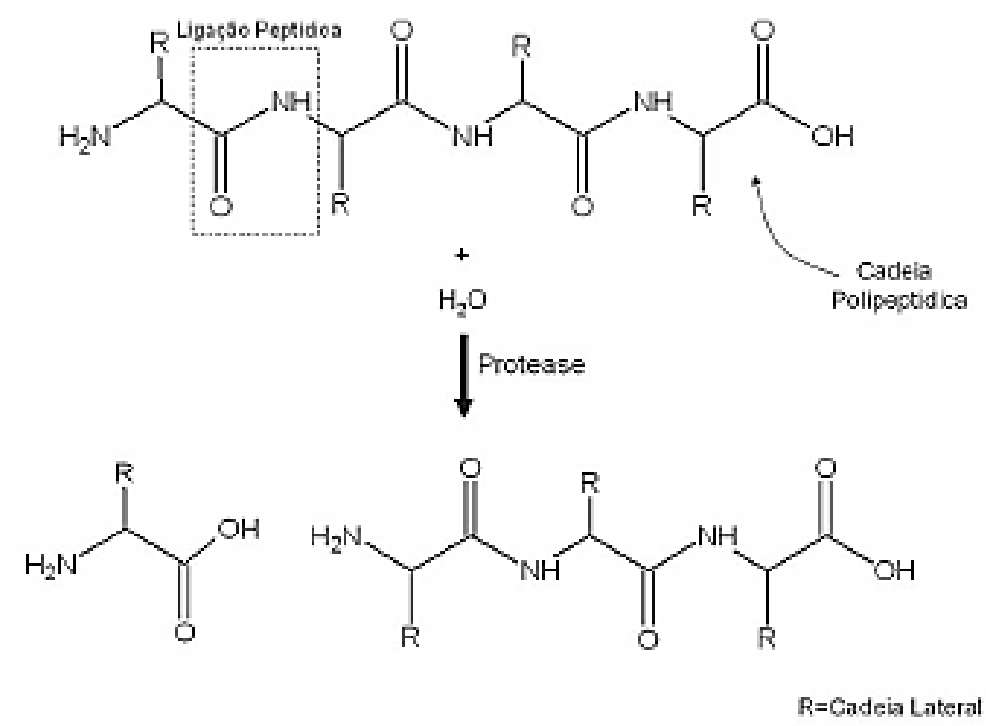

Figura 1 Representação de hidrólise proteica catalisada por protease (LIMA e colaboradores, 2008).

A semelhança entre as enzimas pode ser em relação ao tipo de enzimas dessa família ou em relação à outra enzima que já tenha se mostrado homóloga ao tipo de proteínas da família, ou seja, a uma enzima membro da família. Uma família não precisa ter várias enzimas, pode ter uma única, caso homólogos desta não sejam conhecidos. Cada família é identificada por uma letra representando o tipo de catálise realizada pelas enzimas proteolíticas daquela família (A-aspatica, Ccisteína, G-glutâmica, N-asparagina, P-misturadas, S-serina, T-treonina, Udesconhecido), juntamente com um número. Algumas famílias podem, ainda, ser divididas em subfamílias (21).

Um clã contém todas as proteases que surgiram a partir de uma única origem evolutiva de proteases. Este representa uma ou mais famílias que mostram evidência da sua relação evolutiva pelas suas estruturas terciárias parecidas (15, 
21). Exemplos de enzimas proteolíticas seguindo a classificação MEROPS podem ser vistos na Tabela 1.

Tabela 1 Classificação de algumas proteases segundo a base de dados MEROPS, incluindo família, subfamília, tipo de enzima e clã.

\begin{tabular}{llll}
\hline Família & Subfamília & Tipo de enzima & Clã \\
\hline A1 & A1A & Pepsina A & AA \\
& A1B & Nepentesina & AA \\
A22 & A22A & Presenilina 1 & AD \\
C1 & C1A & Papaína & CA \\
C10 & - & Streptopaína & CA \\
C14 & C14A & Caspase 1 & CD \\
& C14B & Metacaspase YCA1 & CD \\
C60 & C60A & Sortase A & CL \\
& C60B & Sortase B & CL \\
S1 & S1A & Quimitripsina A & PA \\
U32 & - & Colagenase & Não alocado \\
U73 & - & Small protease & Não alocado \\
\hline
\end{tabular}

Estas enzimas constituem um grupo grande e complexo de enzimas que se diferenciam entre si em várias características, como por exemplo, o local do sítio ativo, o mecanismo catalítico, a especificidade ao substrato, o perfil de estabilidade, a temperatura ótima e o $\mathrm{pH}$ ótimo. A especificidade da enzima ao seu substrato é regulada pela natureza do aminoácido e de outros grupos funcionais (alifáticos, aromáticos, com enxofre) perto a ligação peptídica que será clivada (4).

Enzimas proteolíticas possuem papel fundamental em muitos processos fisiológicos como a coagulação do sangue, regulação da expressão gênica e degradação proteica (7). Estas enzimas tem grande importância, pois não só realizam reações proteolíticas, como também regulam muitas cascatas enzimáticas e levam a reações metabólicas envolvendo a quebra de gorduras, carboidratos, entre outros (4). De forma geral, as proteases extracelulares catalisam a hidrólise de proteínas grandes em moléculas menores para a subsequente absorção destes pela 
célula, enquanto as proteases intracelulares desempenham papel crítico na regulação do metabolismo $(7,15)$.

A utilização de plantas como produtor de proteases é regida por vários fatores, como a disponibilidade de terra para o cultivo e a adequação do clima as condições necessárias para o crescimento da planta e a produção da enzima. Como exemplo, de proteases de origem vegetal pode-se citar a papaína, a bromelina e algumas queratinases. As proteases de origem animal são produzidas em grande quantidade e de forma bastante pura, porém sua produção depende do abate de animais, o que envolve questões políticas, dificultando a obtenção de uma enzima de origem animal. As principais proteases produzidas por animais são a tripsina pancreática, quimotripsina, pepsina e renina (7)

As proteases são um dos grupos de enzimas industrialmente importantes (4), pois estas possuem aplicação em diversas indústrias (24) como a indústria de detergente $(25,26)$, indústria alimentícia (27), indústria de couro (28), indústria farmacêutica e de cosméticos $(29,30)$. As proteases podem ter origem microbiana (proteases alcalinas, proteases ácidas), animal (tripsina, pepsina, renina) e vegetal (papaína, bromelina, queratinase) (7).

As proteases são utilizadas há muitos séculos, sua primeira utilização foi na indústria de laticínios como agentes de coagulação do leite para fabricar queijo coalho (4).

O conhecimento de algumas características das proteases é necessário para promover bons resultados nas diferentes aplicações comerciais utilizando essa enzima. Algumas características que devem ser estudadas são $0 \mathrm{pH}$ e a temperatura em que ocorre a maior atividade da enzima, a termoestabilidade, a especificidade ao substrato, os inibidores da enzima, dentre outras.

Para certas aplicações de proteases é necessário que a enzima desempenhe sua atividade ótima em uma faixa de $\mathrm{pH}$ especifica e temperatura específica, como por exemplo na indústria de detergentes para roupas onde são utilizadas proteases que tenham atividade em temperaturas utilizadas em lavanderias, entre $50^{\circ} \mathrm{C}$ e $70^{\circ} \mathrm{C}$ $(5,31)$. Proteases podem ser classificadas de acordo com o seu pH em ácidas, neutras e alcalinas. Proteases ácidas atuam melhor em $\mathrm{pH}$ de 2 a 6 , este grupo é 
constituído em sua maior parte de aspártico-proteases, serino-proteases e metaloproteases. Proteases neutras trabalham em $\mathrm{pH}$ neutro, fracamente alcalino e fracamente ácido e é constituído basicamente de cisteíno-proteases, serinoproteases e metaloproteases. Proteases alcalinas atuam melhor em $\mathrm{pH}$ de 8 a 13 (7).

A estabilidade enzimática também é um parâmetro importante para determinar a viabilidade econômica dos processos industriais, pois uma alta estabilidade é uma vantagem econômica devido à diminuição de gastos com a enzima. Por isso, antes de começar a desenvolver uma formulação envolvendo proteases é necessário acumular informações sobre a estabilidade da enzima em diferentes condições (32, 33).

\subsubsection{Proteases e a indústria alimentícia}

A utilização de enzimas proteolíticas na indústria alimentícia é muito antiga, estas enzimas têm sido utilizadas com frequência para vários fins, como a produção de queijos (34), amaciamento da carne, preparação de hidrolisados de soja (7).

Uma das aplicações de proteases na indústria de laticínios é para limpar incrustação de leite que se forma nas superfícies que trocam de calor durante o tratamento térmico do leite. Estes incrustados, em condições normais de pasteurização contêm de 50 a $60 \%$ de proteínas. A remoção deste material geralmente é feita utilizando hidróxido de sódio em concentração de 0,5\% a 1,5\% ou com uma solução caustica de detergente que fica de 30 a 60 minutos por dia, numa temperatura de 60 a $80^{\circ} \mathrm{C}$ no equipamento de processamento de leite (9). Além de utilizar produtos para a limpeza que geralmente não são biodegradáveis, todo esse procedimento tem um impacto negativo sobre o ambiente, pois aquecer uma grande quantidade de líquido durante 30 a 60 minutos todos os dias gasta muita energia. Os gastos com a limpeza dos aparelhos chegam a $30 \%$ de toda a energia utilizada na produção de laticínios (35).

Paul e colaboradores (36) investigou uma protease queratinolítica produzida por Bacillus tequilensis (hsTKB2) quanto à capacidade de limpar incrustação de leite 
gerada em placas de aço inoxidável, a retirada da incrustação foi considerada satisfatória. Boyce e Walsh (9) investigou 14 fungos quanto à capacidade de produzir proteases com ação na proteína do leite. As enzimas foram avaliadas quanto à capacidade de remover incrustações de leite em aço inoxidável e a protease selecionada como mais apropriada para a aplicação, produzida pelo fungo Schizophyllum commune foi considerada satisfatória.

Para ser uma protease eficaz na limpeza de incrustações de leite e reduzir os impactos ambientais em potencial, a enzima deve degradar a proteína do leite, trabalhar em pH neutro (eliminando a necessidade de neutralização antes do descarte) e em baixa temperatura (diminuindo o gasto de energia) (9).

As proteases também podem ser utilizadas de outra forma na indústria de laticínios uma das maiores aplicações neste setor é na etapa do processamento do queijo e na coagulação. Não existem registros seguros de quando o homem começou a produzir queijos, porém, sabe-se que os primeiros traços da existência desse alimento aconteceram há aproximadamente 3000 anos antes de Cristo (a.C.) (34).

O conjunto de enzimas proteolíticas (renina), obtidas a partir do conteúdo do estômago de bezerros que ainda não foram desmamados, é utilizado pelo homem a décadas. Esta enzima é aplicada para coagular o leite, transformando-o em queijo. É difícil adquirir a renina em quantidades suficientes para utilização industrial, por isso, outras fontes de enzima vêm sendo procuradas há muitos anos $(8,37)$. Ademais, produtos tidos como artesanais são fabricados da mesma forma há séculos, como queijo coagulado por renina, e mantém o sabor e características organolépticas superiores aos produtos fabricados de forma industrial (34), instigando a busca por novas tecnologias.

Uma classificação utilizada na fabricação do queijo é pelo tipo de coagulação, que pode ser ácida ou enzimática. No queijo produzido com leite de cabra, por exemplo, utilizando tecnologia enzimática a coagulação ocorre em 40 minutos, e, sendo por coagulação ácida ocorre em 16 horas (34). A coagulação do leite para transforma-lo em queijo, ocorre pela hidrolise da k-caseína, esta fração da caseína possui papel protetor sobre as partículas coloidais, evitando que se coagulem ou precipitem em presença de cálcio solúvel. A protease age sobre a k-caseína, 
diminuindo a capacidade protetora, as partículas coloidais ficam instáveis na presença de íons cálcio, coagulando o leite (37).

Exemplos são encontrados na literatura. Raposo e Domingos (38) purificaram proteases aspárticas provenientes da planta Centaurea calcitrapa com ação na coagulação do leite. Mazorra-Manzano e colaboradores (39) avaliaram a ação na coagulação do leite de proteases presentes no extrato bruto de extratos de folhas cítricas, estas enzimas foram capazes de coagular o leite em tempos semelhantes às enzimas utilizadas comercialmente. Um extrato bruto, contendo serino proteases, chamado "pomiferin", obtido através do látex de frutos de Machura pomifera foi testado para atividade coagulante apresentando resultado positivo para a coagulação do leite (40).

$\mathrm{Na}$ indústria alimentícia também são utilizadas proteases como papaína, bromelina e ficina para promover o amaciamento da carne. $\mathrm{Na}$ indústria de panificação as proteases atuam melhorando a textura do glúten, alterando a elasticidade e melhorando a cor e o sabor do pão (41).

Hamada e colaboradores (42) utilizaram protease produzida por Aspergillus orizae para aumentar o volume de pão sem glúten produzido com farinha de arroz. A adição de protease melhorou a retenção de gás na massa do pão antes de assar, pois deixou esta mais viscosa, resultando em um pão mais volumoso. Hatta e colaboradores (43) descobriram que a adição das proteases bacilolisina, papaína e subtilisina (Amano Enzyme Inc.) à massa aumentou o volume do pão de arroz sem glúten em 30 a 60\% em comparação com pães não tratados. Estas proteases também diminuíram a dureza do miolo em 10 a 30\% em comparação com pães não tratados.

Naveena e colaboradores (44) desenvolveram método utilizando enzimas proteolíticas das plantas Cucumis trigonus Roxb (Kachri) e Zingiber officinale Roscoe (gengibre rizoma) para amaciar carne de búfalo. A carne tratada com o extrato das plantas citadas, contendo proteases, amaciou a carne além de ter mantido a aparência e sabor. Rawdkuen e colaboradores (45) realizaram estudo a fim amaciar de carne de porco, carne bovina e carne de frango usando extrato bruto enzimático do látex de Calotropis procera, os resultados demonstraram que o extrato pode ser 
usado como uma fonte alternativa de enzimas proteolíticas para o amaciamento eficaz dos três tipos de carne.

$\mathrm{Na}$ indústria de sucos as proteases também possuem utilização. Os sucos de frutas possuem uma turbidez natural, alguns sucos são mais ou menos turvos que outros, isso ocorre especialmente devido à presença de polissacarídeos (pectina, celulose, hemicelulose, lignina e amido), proteínas, taninos e metais (10, 46). A cor e a clareza do suco após o engarrafamento e armazenamento são fatores que afetam a escolha do consumidor (47), tornando-se um importante aspecto a ser levado em consideração pela indústria.

Cerreti e colaboradores (47) utilizaram pectinase e protease para clarificar suco e demonstrou que a combinação entre as duas enzimas foi eficiente em melhorar a turbidez do suco de romã. Mosafa e colaboradores (48) utilizaram nanopartícula contendo papaína e papaína livre para clarificar suco de romã, ambas as enzimas foram eficientes neste processo.

\subsubsection{Proteases e a indústria de couro}

A indústria do couro é considerada um poluidor do meio ambiente e vem sofrendo pressão para controlar esta poluição. Em 2011, alguns curtumes em províncias ricas chinesas foram fechados ou transferidos para áreas remotas para diminuir problemas com poluição (49). Os métodos convencionais utilizados no processamento de couro envolvem produtos químicos como sulfeto de sódio, que criam problemas de poluição (7). Portanto, a fim de reduzir a poluição vinda da indústria do couro, tecnologias mais limpas devem ser pensadas (49).

As proteases encontram aplicação na indústria do processamento de couro durante algumas fases. Na primeira fase é preciso reidratar o couro e realizar a depilação, onde geralmente é utilizada uma protease alcalina para facilitar a remoção dos pelos, esta é utilizada porque o pH básico ajuda na exposição dos folículos pilosos, facilitando sua remoção. Nas fases finais a degradação parcial da queratina e da elastina é essencial e as proteases exercem esse papel, atuando também nesta etapa (50). 
Foroughi e colaboradores (51) estudaram um fungo e duas bactérias isoladas de pele podre, cujas enzimas proteolíticas extracelulares tiveram boa atividade no processo de depilação. Riffel e colaboradores (52) estudaram a atividade depilatória de três bactérias queratinolíticas isoladas de resíduos de penas. As três cepas foram eficazes na promoção da depilação de peles bovinas.

São utilizadas na indústria de couro, tripsina combinada com outras proteases geralmente produzidas por Bacillus ou Aspergillus. A escolha da protease depende de sua especificidade pelas proteínas da matriz (queratina e elastina, por exemplo), e a quantidade de enzima a ser utilizada depende do tipo de couro que se está produzindo (duro ou mole) (7).

Giongo e colaboradores (53) isolaram três espécies queratinolíticas de Bacillus spp. da bacia amazônica com atividade em pH 9,0 que se mostraram eficientes, através de análise microscópica, na promoção da depilação de pele bovina. Hameed e colaboradores (54) estudaram uma protease alcalina produzida por bacillus subtilis isolado a partir de resíduos de curtume para remover proteínas presentes no couro, melhorando a resistência e a força de ruptura deste. Dayanadan e colaboradores (13) estudaram uma enzima proteolítica com atividade em $\mathrm{pH}$ alcalino produzida por Aspergillus tamarii para depilar pele de cabra. A enzima além de promover a depilação do couro, ainda melhorou a resistência deste, promovendo melhora em sua qualidade.

Procurar proteases com alta especificidade para elastina e queratina pode diminuir a quantidade de enzima utilizada no processamento, por serem as mais utilizadas nos processos, além disso, o uso das enzimas na indústria de couro vem aumentando, pois não só previnem problemas de poluição, mas também são eficazes para poupar energia $(7,50)$.

\subsubsection{Proteases e a indústria de detergente}

Hoje em dia, as enzimas são aditivos essenciais em detergentes para aumentar a eficiência de lavagem $(55,56)$. A utilização de enzimas em detergentes oferece diversas vantagens como a substituição ou redução na quantidade de 
componentes nocivos para o ambiente, a economia de energia (pois o detergente com a enzima possibilita a utilização de temperaturas mais baixas), além disso, as enzimas podem ser obtidas a partir de fontes renováveis, são biodegradáveis e agem sem oferecer riscos a vida aquática ou oferecer efeito negativo para 0 tratamento de água (57).

Outra vantagem de extrema importância é a de que detergentes contendo enzimas são mais suaves que os detergentes sem enzimas, estes são mais agressivos e não são compatíveis com a delicadeza exigida pra lavar, por exemplo, louças de porcelana ou madeira (55).

As proteases (tripsina e quimotripsina) foram utilizadas pela primeira vez como um ingrediente ativo em detergentes para lavar roupas em 1913 pelo químico alemão Otto Röhm. A enzima foi adicionada a formulação para retirar manchas proteicas, já que hidrolisa as ligações peptídicas, presentes em proteínas (58).

A protease ideal a ser utilizada na indústria de detergentes deve ter uma ampla especificidade a substratos para viabilizar e facilitar a remoção de vários tipos de sujeiras, como alimentos, sangue e outras secreções corporais, além disso, deve ter alta estabilidade e $\mathrm{pH}$ e temperatura compatíveis com os de outros agentes geralmente adicionados aos detergentes, como quelantes e oxidantes (7).

Em geral, a grande maioria das proteases utilizadas em detergentes são termoestáveis, com atividade em $\mathrm{pH}$ elevado, pois o $\mathrm{pH}$ de detergentes para a roupa é geralmente na faixa de 8 a 12, e tem boa atividade em temperaturas de lavandaria $\left(50-70^{\circ} \mathrm{C}\right)(31)$.

Rai e Mukerjee (59) purificaram uma protease alcalina de $B$. subtilis compatível com detergentes para roupas e comação na remoção de manchas. Vijayalakshmi e colaboradores (60) estudaram uma protease produzida por Bacillus RV.B2.90, manchas de sangue e pigmentos naturais como cenoura, beterraba, folhas verdes, café e chá foram removidos pela enzima facilmente. A protease estudada exibiu compatibilidade com 5 marcas de detergentes para roupas comerciais. Phadatare e colaboradores (61) relataram a produção de protease alcalina por Conidiobolus coronatus e sua aplicação em detergentes comerciais. A enzima foi estável entre valores de $\mathrm{pH}$ 6,0 a 8,5 e a valores de temperaturas de $40^{\circ}$ 
C e foi estável na presença dos detergentes testados, mostrando-se útil para a indústria de detergentes.

Devi e colaboradores (62) estudaram uma protease alcalina expressa pelo fungo filamentoso Aspergillus niger. A enzima foi termoestável e manteve sua atividade superior a $50 \%$ durante 60 minutos a $40^{\circ} \mathrm{C}$ na presença de 4 diferentes marcas de detergente para roupas, mostrando-se apropriada para aplicação na indústria de detergentes. Abidi e colaboradores (11) investigaram a ação na indústria de detergentes de uma protease alcalina produzida pelo fungo Botrytis cinérea. A aplicação na indústria foi comprovada a partir da estabilidade de armazenamento e estabilidade térmica da enzima, compatibilidade com detergentes comerciais testados e desempenho satisfatório no ensaio de lavagem.

Uma protease alcalina produzida por Penicillium godlewskii isolado de amostras de solo coletadas do sul da índia foi estudada para aplicação como aditivo em detergentes, a enzima mostrou estabilidade em vários detergentes comerciais (63). Banik (64) estudou uma protease produzida por Bacillus cereus quanto á sua compatibilidade em detergentes comerciais. A protease de $B$. cereus mostrou atividade maior que $80 \%$ quando incubada com detergentes para roupas a $50{ }^{\circ} \mathrm{C}$ durante $1 \mathrm{~h}$ ou mais, confirmando a compatibilidade.

\subsubsection{Proteases e a indústria cosmética e farmacêutica}

Enzimas possuem grande potencial como ingrediente ativo na formulação de produtos cosméticos. Alguns tipos de protease, incluindo a papaína podem hidrolisar as ligações peptídicas do colágeno e da queratina no estrato córneo da pele. $\mathrm{O}$ controle do dano causado à pele pode consequentemente acionar a via de reparação, fazendo uma camada de pele mais lisa e suave (65).

As colagenases são enzimas que clivam o polipeptídio (66) e têm sido utilizadas há muitos anos em produtos dermatológicos para limpar feridas como, por exemplo, úlceras dérmicas $(14,67)$. Essa aplicação pode dar a impressão de que as proteases são altamente corrosivas e degradantes para a pele, o que não é real. Com o passar do tempo, o aumento da diversidade de proteases e a descoberta de 
diferentes fontes biológicas, o estudo das suas propriedades na pele, a possibilidade de modificações químicas de proteases para melhorar a estabilidade, os estudos para ajustes de concentração, os avanços nos veículos para promover uma melhor liberação da protease e diminuir a irritação causada e estudos relacionados às possíveis aplicações clínicas, permitiram o desenvolvimento de formulações com proteases que parecem ser aplicáveis para outras utilizações dermatológicas que não a limpeza de feridas (14).

Sim e colaboradores(65) desenvolveram uma formulação contendo papaína conjugada a um biopolímero solúvel produzido por S. commune. A loção cosmética contendo $1 \%$ de conjugado de papaína com biopolímero foi mais eficaz para exfoliação do estrato córneo da pele do que um creme que contém $5 \%$ de ácido láctico, um dos agentes esfoliantes populares. Roslan (68) criou um sistema utilizando lipossoma para melhorar a penetração da papaína na pele. A papaína, agente esfoliante que também reduz sinais de envelhecimento, penetrou melhor na pele, o que indica um aumento na concentração do ingrediente ativo na derme.

Além de cosméticos onde a protease é o princípio ativo, estas enzimas também podem ser utilizadas durante processo de produção dos produtos farmacêuticos ou cosméticos. É sabido que a queratinase, um tipo de protease, degrada queratina, e que fontes de queratina como pena, chifre, unhas e cabelo estão disponíveis em abundância na natureza como resíduos (69). Alguns estudos demonstram a utilização de proteases para produzir hidrolizados enzimáticos de queratina, presentes nestes resíduos, com aplicação em cosméticos.

Villa (70) cultivou B. subtilis em meio contendo pena, o filtrado do meio contendo hidrolisados de queratina foi processado e utilizado na formulação de um shampoo e de um condicionador sem enxague. A formulação foi aplicada ao cabelo para avaliar a hidratação (com e sem calor). O resultado mostrou que a hidratação foi mais eficaz com calor, o que sugere uma incorporação mais completa dos hidrolisados nas fibras capilares. Através demicroscopia Eletrônica de Varredura foi possível visualizar depósitos de matéria orgânica na junção das cutículas o que provavelmente colabora para a selagem das cutículas, aumentando o brilho e maciez dos fios. Sanghvi (71) desenvolveu um preparado depilatório contendo queratinase produzida por $B$. subtilis isolado do solo indiano. O preparado foi capaz 
de remover pelos de orelha de coelho mais eficientemente que formulações comerciais.

Proteases podem ser utilizadas em produtos para promover a limpeza da pele, removendo impurezas e deixando a pele mais saudável e bonita. A enzima funciona degradando as proteínas das impurezas presentes na pele, como por exemplo, queratina e proteínas do suor, tornando mais fácil a remoção destas através de detergentes de limpeza da pele. Além disso, a baixa especificidade de algumas proteases é ideal, pois podem degradar várias proteínas que podem estar presentes na superfície da pele (72).

A papaína e a bromelina, dois tipos de proteases, podem ser utilizadas como peeling, para promover o alisamento da pele, exercendo renovação celular e remoção de células mortas da superfície. O peeling exerce atividade queratinolítica removendo células mortas da epiderme e restaurando a mesma (73). A esfoliação da pele pode ser feita por proteases como a Papaína e a Bromelina (74) e outras proteases como uma aspártico-protease ácida (30), esse procedimento promove renovação celular, remoção de células mortas, benefícios na suavidade e textura da pele, na profundidade e quantidade de rugas e na firmeza e espessura da derme e epiderme $(30,74)$.

Uma protease alcalina foi descrita com utilização no controle da descamação da pele xerótica. A enzima atua degradando os elementos coesivos dos corneócitos, ajudando os corneócitos mais superficiais a se destacarem da pele, melhorando a aparência descamativa (75). Smith e colaboradores (30) examinaram as propriedades da pele após exfoliação utilizando protease ácido aspártico ao longo do tempo. A firmeza da pele, alisamento e melhora nas linhas de expressão e rugas foram analisadas. O resultado foi positivo, demonstrou benefícios na aparência da pele após 3 meses de uso do cosmético contendo enzima proteolítica.

Proteases com atividade fibrinolítica ganharam espaço na medicina e indústria farmacêutica devido a sua importância para degradar coágulos de sangue. A fibrina é o componente presente nos coágulos sanguíneos responsável pela ocorrência de distúrbios trombolíticos. O corpo humano produz apenas uma enzima (plasmina) que é capaz de destruir os coágulos sanguíneos, evitando eventos trombolíticos. Já 
existem no mercado medicamentos que ativam a formação de plasmina, porém estes possuem desvantagens como alto custo, meia vida curta, e efeitos colaterais envolvendo complicações hemorrágicas e alérgicas (76).

Silva e colaboradores (77) estudaram produção de protease fibrinolítica de Streptomyces sp. DPUA 1576, isolado da Amazônia, além deste, Souza e colaboradores (76) avaliaram 43 microrganismos do gênero Bacillus para produção de proteases fibrinolíticas, 30 foram confirmados como produtores sendo que 0 melhor foi uma cepa de Bacillus amyloliquefaciens UFPEDA 485.

\subsection{FUNGOS PRODUTORES DE PROTEASES}

Microrganismos representam uma excelente fonte de enzimas, pois possuem uma ampla diversidade bioquímica e facilidade de manipulação genética $(7,78)$.

Nesta direção, fungos e bactérias, representam uma fonte muito atraente de proteases, uma vez que podem ser cultivadas em grande escala num curto período de tempo por métodos de fermentação estabelecidos, e produzem uma grande quantidade do produto desejado. Além disso, as proteínas microbianas tem uma vida útil longa e podem ser armazenadas com facilidade, e durante semanas, sem perda significativa de atividade (31).

Em geral, as proteases microbianas são de natureza extracelular e são diretamente excretadas para o caldo de fermentação pelo produtor, simplificando significativamente o processo de obtenção da enzima em comparação com as proteases obtidas a partir de plantas e animais (31).

Muitos fungos produtores de proteases vêm sendo estudados, como por exemplo, o fungo Beauveria felina, um produtor de protease alcalina (78), Aspergillus flavus produtor de serino protease alcalina (79), A. oryzae produtor de proteases ácida, neutra e alcalina (7), A. foetidus, produtor de protease ácida (80), Purpureocillium lilacinum, produtor de protease queratinolítica (69), Aspergillus parasíticus, produtor de protease queratinolítica (29), entre muitos outros. Essa alta quantidade de estudos envolvendo proteases produzidas por fungos se deve ao fato de que as proteases fúngicas geralmente são ativas em uma faixa ampla de $\mathrm{pH}$ (4 a 
11) e exibem alta quantidade de substratos possíveis. Além disso, as proteases de origem microbiana são preferidas em vista de proteases de fontes vegetais e animais, pois elas possuem quase todas as características desejadas para a suas aplicações biotecnológicas (7).

\subsection{FUNGOS ENDOFÍTICOS}

Fungos e bactérias são encontrados habitando seres vivos, ar, água, solo, comprovando a versatilidade destes organismos que possuem a capacidade de se desenvolver em ambientes muitas vezes inóspitos (81). Muitas plantas, especialmente as lenhosas podem conter centenas e até milhares de espécies fúngicas (82).

Fungos endofíticos são microrganismos, ainda relativamente pouco estudados (82) que residem no interior do tecido das plantas vivas sem causar efeitos negativos a ela (82-84). Os fungos endofíticos habitam geralmente os tecidos da planta que ficam acima do solo como folhas, caules, casca e estruturas reprodutivas. Esta característica os diferencia dos fungos micorrízicos, porém, esta distinção não é firme, pois fungos endofíticos podem também habitar tecidos da raiz $(82,85)$. Este grupo de fungos também se diferencia dos fungos fitopatogênicos que podem causar doenças e prejudicar a planta, e ainda, dos fungos epifíticos, que colonizam a superfície dos órgãos e tecidos vegetais (86).

Foi Anton de Bary quem primeiro delineou uma possível diferença entre os fungos endofíticos e patógenos de planta, porém estes eram considerados uma curiosidade micológica que não cumpria nenhuma função $(86,87)$. A primeira menção destes fungos é bastante antiga e ocorreu no inicio do século XIX, porém, foi ao final dos anos 70 que começaram a chamar atenção. Nessa época verificouse que os endófitos possuíam propriedades de interesse, como por exemplo, proteger a planta de pragas, contra patógenos e contra herbívoros (86).

É aceito que em cada uma das quase 300.000 espécies de plantas existentes, estão presentes pelo menos uma ou mesmo centenas de cepas de endófitos, incluindo fungos endofíticos $(85,88)$. Em geral os microrganismos adentram a planta 
por aberturas e feridas presentes na mesma, uma entrada bastante comum é pela raiz da planta (86). A preferência do fungo pelo hospedeiro é um fenômeno que ainda não está elucidado, a especificidade de acolhimento exige uma estreita adaptação entre o hospedeiro e o fungo, sugerindo uma influencia mutua decorrente de uma antiga convivência entre estes. Em longo prazo essa associação torna-se permanentemente impressa na constituição genética de ambos, que finalmente, desenvolvem sistemas genéticos complementares $(87,88)$, apenas em caso de lesões na planta, stress ou morte os fungos endofíticos podem crescer ativamente e rapidamente em seus hospedeiros, produzindo sintomas e causando males à planta (87).

Apesar de alguns endófitos isolados até o momento não possuírem efeitos conhecidos sobre seu hospedeiro, vários demonstram ter funções bem definidas nas plantas hospedeiras. Alguns acarretam modificações fisiológicas, alguns possuem a capacidade de modificar morfologicamente o tecido dos hospedeiros e outros, como já citado, protegem a planta contra insetos, herbívoros ou patógenos (86).

De um modo geral, dois grandes grupos de fungos endófitos são conhecidos, os fungos endofíticos clavipitaceous (C-endófitos) e os não-clavipitaceous (NCendófitos). Essa distinção é baseada nas plantas hospedeiras, na taxonomia e na função ecológica. Os C-endófitos infectam algumas gramíneas, enquanto os NCendófitos vivem em tecidos assintomáticos de plantas não vasculares, samambaias, coníferas e angiospermas. Até o momento, a maior quantidade de estudos estão concentrados no grupo dos C-endófitos, essa concentração é consequência dos impactos agrícolas positivos e significativos dos C-endófitos em seus hospedeiros (85).

Breen (1994), por exemplo, revisou os efeitos dos fungos endofíticos do gênero Acremonium na resistência que seu hospedeiro demonstra contra insetos (89), e em seu outro trabalho Breen (1993) estudou que em certas gramíneas a presença de fungos endofíticos do gênero Acremonium minimiza o ataque de insetos, como por exemplo, Spodoptera frugiperda e Spodoptera eridana, e, não sendo atacadas por insetos estas espécies de gramíneas tornam-se mais vigorosas e resistem melhor às doenças (90). 
Nos tempos atuais, é sabido que os fungos endofíticos, além de exercerem importantes funções de sobrevivência do hospedeiro, podem produzir metabólitos primários e secundários como antibióticos, toxinas, fatores de crescimento, enzimas e inúmeros outros produtos de interesse comercial e biológico (86).

A busca de novos metabólitos secundários devem se concentrar em organismos que habitam novos biótopos, pois é sabido que a formação de novos metabólitos acontece pela necessidade do organismo de exercer alguma função específica no local onde habita, isso torna os fungos endofíticos um grupo de muito interesse (18).

É sabido que algumas vezes o fungo endofítico produz metabólitos também produzidos pela planta hospedeira, Stierle e colaboradores (91) foram os primeiros a mostrar que o fungo Taxomyces adrenae isolado da planta Taxus brevifolia era capaz de produzir o Taxol, um anticancerígeno também produzido por seu hospedeiro. Desde então outros estudos surgiram para corroborar com este, Guo e colaboradores (92), Strobel e colaboradores (93), Li e colaboradores (94), estudaram fungos endofíticos produtores de taxol, isolados de plantas que também produziam este metabolito.

Aly e colaboradores (95) citam que Lingqi e colaboradores (2000) estudaram o Vincristina, outro anticancerígeno produzido pela planta Catharanthus roseus (Apocynaceae), e foi detectado em Fusarium oxysporum endofítico vindo da mesma planta. Tan e Zou (96) acreditam que com o tempo existe uma recombinação genética do fungo endofítico com sua planta hospedeira, e por isso, alguns fungos endofíticos produzem metabólitos originalmente produzidos por seu hospedeiro.

Assim sendo, fungos endofíticos podem tornar-se uma fonte alternativa de produção de taxol (92), assim como de outros metabólitos que se pensava serem produzidos apenas por seus hospedeiros, e, que podem de alguma forma ter a produção limitada, seja pela alta quantidade da planta utilizada para conseguir o metabolito de interesse ou por qualquer outro motivo que torne a obtenção do metabólito difícil através da planta.

É grande o numero de metabólitos produzidos por fungos que já foram estudados, Tam e Zou (96) cita a produção de alcaloides, esteroides, terpenóides, 
quinonas, flavonoides, peptídeos, fenol e ácidos fenólicos entre outros por esta classe de fungos.

Chapla e colaboradores (97) isolaram e identificaram mais de 20 metabólitos secundários produzidos por fungos endofíticos. Dentre eles, do endófito Penicillium sp., isolado de Alibertia macrophylla foram isoladas 3 isocoumarinas (inibidores de serina protease). Dos fungos Penicillium sp. e Xylaria sp. isolados de Alibertia macrophylla e Piper aduncum foram isoladas, também, 3 isocoumarinas. No mesmo trabalho o autor isolou ainda 4 sesquiterpenos eremofilanos de endófito Xylaria sp. isolados da planta Piper aduncum.

No trabalho produzido por Lindstron e belanger (98) foi demonstrada a expressão da enzima protease pelo fungo endofítico Acremonium thyphinum, a enzima foi purificada e notou-se a alta presença desta no seu hospedeiro, sugerindo que esta expressão elevada pode estar envolvida com a interação simbiótica entre a planta e o fungo.

Em outro trabalho, sete fungos endofíticos foram analisados para a produção de enzimas extracelulares (amilase, celulase, chitinase, lacase, lipase, protease e tirosinase). As atividades de lipase e celulase estavam presentes em todos os fungos, enquanto as de amilase e protease em alguns (99).

Fuentes-ramirez (100) citou bactérias endofíticas do gênero Acetobacter diazotrophicus produtoras de ácido indolacético (AIA), um fator de crescimento que trabalha estimulando o crescimento alongando raízes e caules.

Silva (101) analisou 29 fungos endofíticos isolados de folhas, caules e raízes da planta Annona squamosa L. quanto à produção de algumas enzimas extracelulares. Dezenove fungos isolados apresentaram atividade lipolítica e cinco fungos isolados apresentaram atividade proteolítca.

Algumas enzimas produzidas por fungos endofíticos já existentes no mercado, como por exemplo, $\beta$-galactosidases, proteases, lipases, amilases, celulases, $\beta-1,6$ glucanases e liases têm sido altamente utilizadas na indústria de alimentos, produção de detergente, ração animal, indústria de fabricação de cerveja e indústria farmacêutica. As enzimas xilanase, lacase e mananase e têm sido empregadas na indústria de papel e indústria têxtil. As enzimas citadas à cima foram produzidas por 
vários fungos endofíticos isolados de plantas diferentes, como é possível ver na Tabela 2 (17).

Tabela 2 produção de enzimas por fungos endofíticos e as plantas de que foram isolados (Borges et al. 2009)

\begin{tabular}{|c|c|c|}
\hline Fungo & Enzima & Planta \\
\hline Neotyphodium sp & $\beta-1,6$-glucanase & Poa ampla \\
\hline Colletotrichum musae & Fosfatase ácida & Musa cavendish \\
\hline Neotyphodium Iolii & $\beta-1,6$-glucanase & Poa ampla \\
\hline Epichloe festucae & $\beta-1,6$-glucanase & Poa ampla \\
\hline Monotospora sp & Lacase & Cynodon dactylon \\
\hline Mycelia sterilia & Lacase & Rhus chinensis Mill. \\
\hline Colletotrichum sp & $\begin{array}{l}\text { Celulase, mananase, protease, } \\
\text { xylanase }\end{array}$ & $\begin{array}{l}\text { Cinnamomum iners } \\
\text { Camellia sinensis }\end{array}$ \\
\hline Pestalotiopsis $s p$ & Celulase, mananase & Manglietia garrettii \\
\hline Phoma sp & Celulase, mananase, protease & Garcinia cowa \\
\hline Phomopsis sp & Celulase, mananase, xylanase & $\begin{array}{l}\text { Garcinia cowa Trichilla } \\
\text { connaroides Cinnamomum } \\
\text { iners }\end{array}$ \\
\hline Xylaria sp. & $\begin{array}{l}\text { Celulase, mananase, xylanase, } \\
\text { protease }\end{array}$ & Trichilla connaroides \\
\hline Mycelia sterilia & Celulase, mananase, protease & Trichilla connaroides \\
\hline Neotyphodium sp & $\beta$-1,6-glucanase & Poa ampla \\
\hline Neotyphodium $s p$ & Chitinase & Poa ampla \\
\hline Colletotrichum sp & $\begin{array}{l}\text { B-galactosidase, } \\
\text { ramnogalacturonana, liase, } \\
\text { acetilesterase }\end{array}$ & Abelmoschus esculentus \\
\hline Acephala applanata & Amilase, Lacase, protease & Conifer roots \\
\hline Acremonium typhinum & Protease & Poa ampla \\
\hline Melanconium apiocarpum & Lacase, amilase, protease & Alnus viridis \\
\hline Cercospora kikuchii & Lipase & Tithonia diversifolia \\
\hline
\end{tabular}

Os metabólitos produzidos pelos fungos endofíticos são ainda pouco estudados e de grande importância para a ciência, já que podem possuir características diferentes das já conhecidas, justificando a realização deste trabalho. 


\section{OBJETIVOS}

Este trabalho teve como objetivo produzir e purificar protease, oriunda de fungos endofíticos isolados de plantas nativas do Cerrado Brasileiro.

Para atingir este objetivo foram desenvolvidas as seguintes etapas:

- Isolamento de fungos endolíticos oriundos de plantas do Cerrado

> Avaliação qualitativa da produção de proteases pelos fungos isolados

> Avaliação quantitativa da produção de proteases pelos fungos isolados

> Estudo da relação C:N utilizada como fonte para a produção da enzima de interesse

> Caracterização parcial das proteases extracelulares produzidas pelos fungos selecionados

> Purificação parcial de uma protease produzida pelo fungo endofítico selecionado

- Avaliação de uma provável aplicação industrial da enzima parcialmente purificada 


\section{MATERIAIS E MÉTODOS}

\subsection{FOLHAS DO CERRADO}

Foram utilizadas folhas de 13 espécies de plantas provenientes do cerrado brasileiro, as quais foram coletadas em dias e horários diferentes entre os meses de outubro/2014 e janeiro/2015. Apenas as folhas foram colhidas e utilizadas para o experimento. No mesmo dia da colheita foi realizado o procedimento para isolar os fungos endofíticos, garantindo assim que a folha não estivesse ressecada, o que dificulta o processo de isolamento. Na tabela a seguir (Tabela 3) é possível visualizar os nomes científicos e populares das plantas cujas folhas foram colhidas e utilizadas.

Tabela 3. Nome científico das plantas utilizadas no isolamento de fungos endofíticos.

\begin{tabular}{|c|c|c|}
\hline Nome científico & Nome popular & $\begin{array}{l}\text { Parte da planta } \\
\text { utilizada }\end{array}$ \\
\hline Sapindus saponária $L$. & $\begin{array}{l}\text { Sabão de mico, Saboeiro, } \\
\text { Saboneteira }\end{array}$ & Folha \\
\hline Morus nigra $L$. & Amoreira preta & Folha \\
\hline Calophyllum brasiliense & Guanandi, Jacareúba, Landim & Folha \\
\hline Eriotheca pubescens & Paineira do cerrado & Folha \\
\hline Ourátea hexasperma & Vassoura de bruxa, Batibutá & Folha \\
\hline Dalbergia miscolobium & $\begin{array}{l}\text { Pau preto, Jacarandá do } \\
\text { cerrado, Cabiuna do campo }\end{array}$ & Folha \\
\hline Pouteria torta & $\begin{array}{l}\text { Grão de galo, Guapeva, } \\
\text { Jabuticaba de macaco }\end{array}$ & Folha \\
\hline Stryphnodendron adstringens & $\begin{array}{l}\text { Barbatimão, Barbatimão } \\
\text { verdadeiro }\end{array}$ & Folha \\
\hline Kielmeyera coriacea & Pai santo, Boizinho & Folha \\
\hline Solanum lycocarpum & $\begin{array}{l}\text { Lobeira, Fruto de lobo, } \\
\text { Guarambá }\end{array}$ & Folha \\
\hline Caryocar brasiliensis & Pequizeiro, piquiá & Folha \\
\hline Tabebuia ochracea & Ipê do cerrado, Ipê & Folha \\
\hline Psidium guajava L. & Goiabeira & Folha \\
\hline
\end{tabular}




\subsection{ISOLAMENTO DE FUNGOS ENDOFÍTICOS}

As folhas colhidas foram lavadas com água corrente e detergente líquido, sem ocasionar rompimento do tecido, posteriormente cada folha foi totalmente imersa em recipiente contendo álcool $70 \%$ por 60 segundos. Em seguida as folhas foram imersas, em sequência, em três recipientes contendo hipoclorito de sódio $2 \%$ por 60 , 90 e 180 segundos respectivamente, seguindo novamente para um quinto recipiente contendo álcool $70 \%$ por mais 60 segundos. Finalmente, as folhas foram imersas por 30 segundos, com agitação mecânica, numa sequência de três recipientes contendo água destilada autoclavada para a completa retirada de restos de hipoclorito e álcool. Para enxugar o excesso de água da folha descontaminada foi utilizado papel filtro previamente esterilizado (102).

Uma amostra de $500 \mu \mathrm{L}$ da última água de lavagem foi inoculada em placa e utilizada como controle negativo de crescimento microbiano. Fragmentos da folha foram cortados com a ajuda de uma tesoura esterilizada e depositados sobre uma placa de Petri contendo $20 \mathrm{~mL}$ de meio ágar sabouraud dextrose. Um segundo controle foi utilizado, imprimindo-se a superfície da folha em placa de meio ágar sabouraud dextrose, para certificar-se a completa descontaminação da superfície. As placas foram incubadas a $28^{\circ} \mathrm{C}$ durante um período de 3 a 5 dias (acompanhando diariamente o crescimento fúngico). Foram feitos repiques para placas contendo $20 \mathrm{~mL}$ de meio ágar sabouraud dextrose sempre que surgia uma nova colônia de fungos, isolando-a. Após o completo isolamento de cada colônia fúngica diferente que cresceu nas placas-teste (Figura 2) discos de $5 \mathrm{~mm}$ do micélio de cada fungo foram armazenados em solução de armazenamento composta por glicerol $10 \%$ em água destilada, a $-80^{\circ} \mathrm{C}$ com código atribuído a cada um deles. 


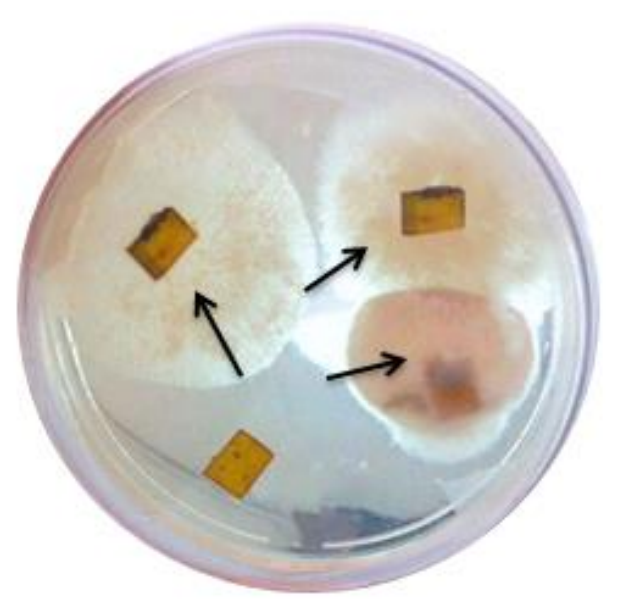

Figura 2. Placa-teste demostrando o isolamento de fungos endofíticos crescidos a partir de folha de Eriotheca pubescens. Foto tirada após 48 horas de encubação da placa em estufa a $28^{\circ} \mathrm{C}$.

\subsection{CONDIÇÃO DE CULTIVO}

Os fungos endofíticos isolados previamente, armazenados em solução de armazenamento a $-80^{\circ} \mathrm{C}$ para conservação, foram reativados em placas de Petri contendo meio ágar Sabouraud dextrose e incubados em estufa a $28^{\circ} \mathrm{C}$ por 7 dias até seu crescimento. Para cada fungo isolado foi inoculado um disco de $5 \mathrm{~mm}$ de diâmetro de micélio em Erlenmeyer de $250 \mathrm{~mL}$ contendo $50 \mathrm{~mL}$ de meio de cultivo (peptona 2\%, extrato de levedura $1 \%, \mathrm{KH}_{2} \mathrm{PO}_{4} \mathrm{0,2} \%, \mathrm{NaH}_{2} \mathrm{PO}_{4} 0,8 \%$ e $\mathrm{MgSO}_{4}$ $0,25 \%$ ). Cada cultura foi incubada a $28^{\circ} \mathrm{C}$ por 7 dias. Após a incubação as culturas foram filtradas utilizando papel de filtro em funil de Büchner acoplado a um kitassato, com condição de baixa pressão criada por bomba de vácuo. Este filtrado foi denominado extrato bruto (EB).

\subsection{AVALIAÇÃO QUALITATIVA DA PRODUÇÃO DE PROTEASE}

Para averiguar a produção de protease pelos fungos endofíticos isolados, o extrato bruto (EB) de cada um dos fungos isolados foi inoculado em placa contendo $10 \%$ de leite desnatado em ágar (24). O ágar foi adicionado em tampão citrato fosfato $0,1 \mathrm{M} \mathrm{pH} 5$ e esterilizado separadamente do leite para evitar a formação de coágulos. Posteriormente o leite foi adicionado ao ágar em condições assépticas. 20 
$\mathrm{mL}$ do meio foi vertido em cada placa de Petri estéril, ainda quente. A leitura das placas foi feita após 24 horas, onde os fungos prováveis produtores de proteases foram identificados através da formação de um halo translucido ao redor das colônias. Foi considerado provável produtor de protease o fungo que apresentou o halo independentemente de seu diâmetro.

\subsection{AVALIAÇÃO QUANTITATIVA DA PRODUÇÃO DE PROTEASE - ENSAIO ENZIMÁTICO}

A quantificação da atividade de protease foi realizada para todos extratos brutos dos fungos com halo de protease positivo.

A atividade proteolítica foi determinada segundo Charney e Tomarelli (103) com modificações, utilizando azocaseína como substrato e ácido tricloroacético como agente de precipitação. A azocaseína é um derivado da caseína, onde foi adicionado um grupo sulfonilamida. A azocaseína possui cor vermelho-alaranjada. A digestão deste substrato por uma protease resulta na formação de componente de cor alaranjada solúvel em ácido tricloroacético (TCA), que após centrifugação é analisada em espectrofotômetro. A formação do composto cromóforo ocorreu pela adição de solução de hidróxido de potássio $5 \mathrm{~N}$. A leitura da intensidade de cor ocorreu a $430 \mathrm{~nm}$ em espectrofotômetro (Shimadzu UV-1800). Uma unidade de atividade de protease foi definida como a quantidade de enzima que produz uma diferença de 0,01 de absorbância por minuto de reação entre o branco da reação e a amostra nas condições de ensaio. A reação foi iniciada incubando-se $500 \mu \mathrm{L}$ de amostra (filtrado fúngico) com $500 \mu \mathrm{L}$ de Azocaseína (Sigma Aldrich, St Louis, MO, EUA) $0,5 \%(\mathrm{~m} / \mathrm{v})$ diluído em tampão acetato fosfato $0,1 \mathrm{M} \mathrm{pH} \mathrm{5,0,} \mathrm{a} 55^{\circ} \mathrm{C}$ durante 40 minutos. Após o tempo a reação foi parada através da precipitação da caseína não hidrolisada utilizando-se $500 \mu \mathrm{L}$ de Ácido tricloroacético (TCA) (Sigma Aldrich, St Louis, MO, EUA) $10 \%$ (m/v). Com a reação interrompida a amostra foi centrifugada a 6000 rpm por 10 minutos, $500 \mu \mathrm{L}$ do sobrenadante foi transferido para um novo tudo, onde adicionou-se $500 \mu \mathrm{L}$ de $\mathrm{KOH} 5,0 \mathrm{~N}$. A intensidade da cor laranja induzida pela reação com o $\mathrm{KOH}$ (característica dos grupos $\mathrm{AZO}$ em $\mathrm{pH}$ alcalino) foi medida através do espectrofotômetro. 
Foi feito um branco da reação para zerar o espectrofotômetro substituindo-se o extrato enzimático por $500 \mu \mathrm{L}$ de tampão acetato fosfato $0,1 \mathrm{M} \mathrm{pH} 5,0$. Além disso, foi feito um branco para cada amostra, adicionando-se TCA antes do extrato enzimático. Todas as amostras, inclusive o branco do aparelho, foram adicionadas de azocaseína.

\subsection{QUANTIFICAÇÃO DE PROTEÍNA}

O teor de proteínas foi determinado por Bradford (104). No tubo teste adicionou-se $100 \mu \mathrm{L}$ de amostra e $1 \mathrm{~mL}$ de reagente de Bradford á temperatura ambiente deixando em repouso por 5 minutos. Após o tempo de reação foi realizada a leitura em espectrofotômetro (Shimadzu UV-1800) a 595 nm. Como padrão utilizou-se albumina de soro bovino (5-200 $\mu \mathrm{g} / \mathrm{mL}$, Sigma). O preparo do reagente de Bradford se deu pela dissolução de 100 mg de azul de Coomassie G-250 (Bio-rad) em uma mistura de $100 \mathrm{~mL}$ de ácido fosfórico (Dinâmica) a $85 \%$ e $50 \mathrm{~mL}$ de metanol (Vetec) a 95\%, completou-se o volume para $1 \mathrm{~L}$ com água destilada.

\subsection{EFEITO DO pH NA ATIVIDADE PROTEOLÍTICA}

Foram escolhidos os produtores de protease que apresentaram maior atividade proteolítica para realização de experimentos para o melhor $\mathrm{pH}$ e a temperatura de maior atividade proteolítica. $\mathrm{O}$ efeito do $\mathrm{pH}$ na atividade de protease foi verificado segundo Cavello e colaboradores(69) com modificações. Modificou-se o pH do tampão utilizado na preparação da azocaseína 0,5\% (m/v), para este experimento utilizou-se pH entre 5,0 a 9,0. Foi utilizado tampão acetato de sódio 0,1M para o pH 5,0 , tampão citrato fosfato $0,1 \mathrm{M}$ para $\mathrm{pH} 6,0$ e 7,0 e tampão tris/ $\mathrm{HCl}$ para $\mathrm{pH}$ 8,0 e 9,0. A quantificação de protease em cada amostra foi realizada como citado no subitem 4.4, porém, utilizou-se a Azocaseína com o pH modificado. Todos os testes foram realizados em triplicata. 


\subsection{EFEITO DA TEMPERATURA NA ATIVIDADE PROTEOLÍTICA}

O efeito da temperatura na atividade proteolítica foi verificado para os melhores produtores de protease variando-se a temperatura de incubação das amostras de $30^{\circ} \mathrm{C}$ a $70^{\circ} \mathrm{C}$. O substrato utilizado no ensaio enzimático foi a Azocaseína na concentração de $0,5 \%$. O ensaio foi realizado no pH ótimo de cada amostra segundo Cavello e colaboradores (69) com modificações.

\subsection{ESTUDO DO MELHOR MEIO DE CULTIVO PARA PRODUÇÃO ENZIMÁTICA}

A cepa do fungo endofítico que exibiu a maior produção de protease e obteve melhores condições de temperatura e $\mathrm{pH}$, foi ativada em meio ágar sabouraud dextrose em placa de Petri e encubada a $28^{\circ} \mathrm{C}$ por 7 dias. Discos de $5 \mathrm{~mm}$ de diâmetro de meio contendo micélio proveniente do cultivo em placa de Petri foram inoculados em frascos Erlenmeyer de $250 \mathrm{~mL}$ contendo $50 \mathrm{~mL}$ de meio líquido. Para determinar a melhor fonte de nitrogênio para crescimento do fungo, foram testados 4 diferentes constituições de meios líquidos onde a fonte de nitrogênio de cada um foi modificada. Os 4 meios foram constituídos de meio mínimo (MM) contendo $\left(\mathrm{KH}_{2} \mathrm{PO}_{4}\right.$ $0,2 \%, \mathrm{NaH}_{2} \mathrm{PO}_{4} 0,8 \%$ e $\mathrm{MgSO}_{4}$ 0,25\%) suplementados com peptona (P), extrato de levedura $(\mathrm{L})$ e glicose $(\mathrm{G})$ em diferentes combinações e concentrações. Os 4 meios, MMP $\left(\mathrm{KH}_{2} \mathrm{PO}_{4} 0,2 \%, \mathrm{NaH}_{2} \mathrm{PO}_{4} 0,8 \%, \mathrm{MgSO}_{4} \mathrm{0}, 25 \%\right.$, peptona $\left.2 \%\right), \mathrm{MML}\left(\mathrm{KH}_{2} \mathrm{PO}_{4}\right.$ $0,2 \%, \mathrm{NaH}_{2} \mathrm{PO}_{4} 0,8 \%, \mathrm{MgSO}_{4}$ 0,25\%, extrato de levedura 1\%), MMPL $\left(\mathrm{KH}_{2} \mathrm{PO}_{4}\right.$ $0,2 \%, \mathrm{NaH}_{2} \mathrm{PO}_{4} 0,8 \%, \mathrm{MgSO}_{4} 0,25 \%$ peptona $2 \%$, extrato de levedura $1 \%$ ), MMPLG $\left(\mathrm{KH}_{2} \mathrm{PO}_{4} 0,2 \%, \mathrm{NaH}_{2} \mathrm{PO}_{4} 0,8 \%, \mathrm{MgSO}_{4} 0,25 \%\right.$, extrato de levedura $1 \%$, peptona $2 \%$, glicose $2 \%$ ) foram autoclavados a $120^{\circ} \mathrm{C}$ por 20 minutos e incubados a $28^{\circ} \mathrm{C} \mathrm{com}$ rotação de $120 \mathrm{rpm}$ por 7 dias contendo disco de micélio de $5 \mathrm{~mm}$ do fungo BR. No sétimo dia o cultivo cada meio foi filtrado utilizando papel de filtro em um kitassato acoplado a uma bomba de vácuo e quantificou-se a quantidade de protease produzida pelo fungo no filtrado de cada meio. $O$ experimento foi realizado em triplicata biológica e técnica. A Figura 3 esquematiza a composição de cada meio. 


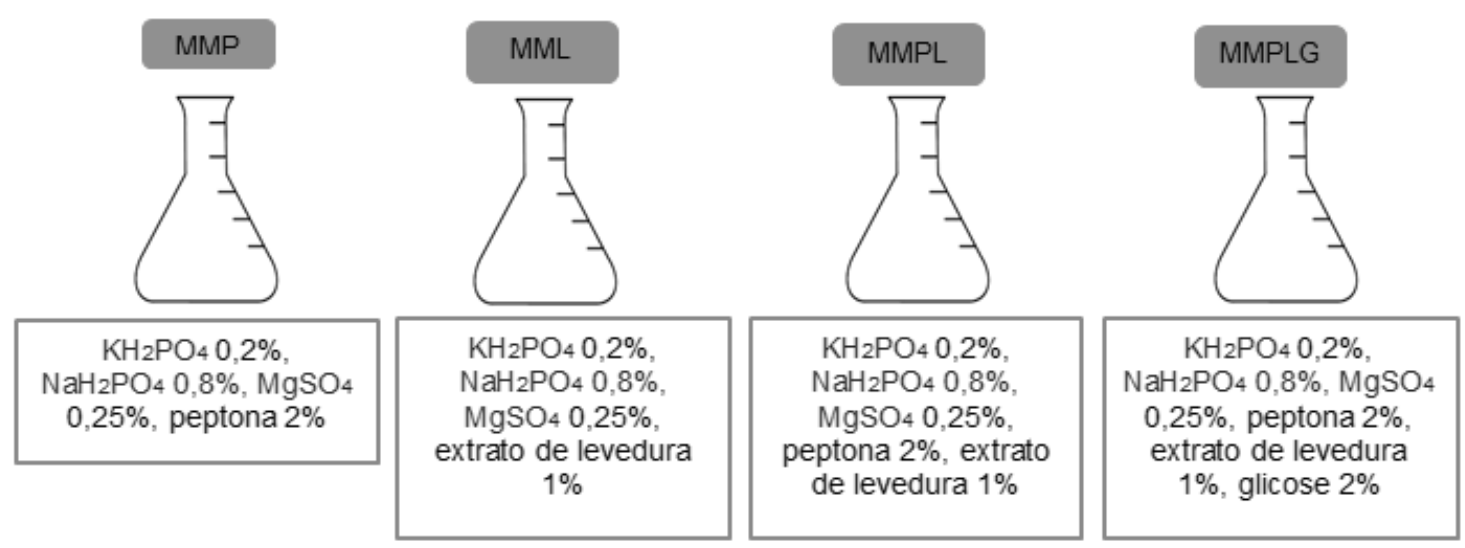

Figura 3. Esquema da composição dos meios de cultivo para avaliar melhor fonte de nitrogênio

\subsection{CURVA DE CRESCIMENTO E PARÂMETROS CINÉTICOS}

Para determinar a produção de protease, o pH do meio, a biomassa e a concentração de glicose em função do tempo, foi realizada uma curva de crescimento onde $\mathrm{o}$ fungo foi cultivado em meio líquido $\left(\mathrm{KH}_{2} \mathrm{PO}_{4} \mathrm{0}, 2 \%, \mathrm{NaH}_{2} \mathrm{PO}_{4}\right.$ $0,8 \%, \mathrm{MgSO}_{4} \mathrm{2}, 25 \%$, extrato de levedura $1 \%$, peptona $2 \%$, glicose $2 \%$ ) incubado a $28^{\circ} \mathrm{C}$ e $120 \mathrm{rpm}$. A cada 24 horas retirou-se uma amostra para realizar as medições de $\mathrm{pH}$, concentração de protease no meio e quantidade de biomassa por 20 dias consecutivos. A medição da concentração de biomassa fúngica foi realizada por peso seco, o pH foi medido com pHmetro (Jenway $3510 \mathrm{pH}$ Meter) e a produção de protease foi realizada segundo Charney e Tomarelli (103), a quantidade de glicose foi medida com um kit (Dolles).

Para a determinação dos parâmetros cinéticos foram utilizados os resultados obtidos de biomassa e atividade enzimática. Foram calculados os seguintes parâmetros: Velocidade específica de crescimento ( $\mu$ máx), produtividade específica em enzima ( $\left.Y_{E m a ́ x}\right)$ e fator de conversão de biomassa em enzima $\left(Y_{E / X}\right)$, segundo as equações expressas na Figura 4. 


$$
\mu \mathrm{máx}=\frac{\operatorname{Ln} \frac{\text { biomassa final }(\mathrm{g})}{\text { biomassa inicial }(\mathrm{g})}}{\Delta t(h)}
$$

$$
\text { Yemáx }=\frac{\frac{\text { Atividade }(U I)}{\text { Horas }}}{\text { Biomassa (g) }}
$$

$$
Y e / x=\frac{\text { Atividade }(\mathrm{UI})}{\operatorname{Biomassa}(\mathrm{g})}
$$

Figura 4. Equações utilizadas para cálculo dos parâmetros cinéticos: velocidade específica de crescimento ( $\mu$ máx), produtividade específica em enzima $\left(Y_{\text {Emáx }}\right)$ e fator de conversão de biomassa em enzima $\left(\mathrm{Y}_{\mathrm{E} / \mathrm{X}}\right)$.

\subsection{PURIFICAÇÃO DA PROTEASE EXPRESSA PELO FUNGO ENDOFÍTICO}

\subsubsection{Cromatografia}

Utilizou-se para a purificação o aparelho AKTA Pure system (GE healthcare biosciences, uppsala, Suíça). Primeiramente, o extrato bruto foi completamente liofilizado com a finalidade de concentrar a proteína e foi ressuspenso em tampão fosfato de sódio $0,1 \mathrm{M} \mathrm{pH} \mathrm{7,0.} \mathrm{A} \mathrm{amostra} \mathrm{foi} \mathrm{filtrada} \mathrm{em} \mathrm{filtro} \mathrm{Millex} \mathrm{13mm} \mathrm{(Millipore,}$ Beadford, MA) com tamanho de poro de $45 \mu \mathrm{M}, 1 \mathrm{~mL}$ de amostra contendo 188,3 $\mu \mathrm{g} / \mathrm{mL}$ de proteína foi aplicada em coluna de troca aniônica Hitrap DEAE FF 1,0 mL (GE healthcare biosciences) previamente equilibrada com tampão fosfato de sódio $0,1 \mathrm{M} \mathrm{pH} 7,0$. Lavou-se a coluna com gradiente linear de 0 a $1 \mathrm{M}$ de $\mathrm{NaCl}$ em tampão fosfato de sódio $0,1 \mathrm{M}$, o fluxo utilizado neste método foi de $0,300 \mathrm{~mL} / \mathrm{min}$. Frações de $1 \mathrm{~mL}$ foram coletadas e a quantidade total de proteína e a atividade proteolítica foram determinadas. $O$ fluxograma (Figura 5 ) a seguir detalha o processo de purificação da enzima de interesse. 


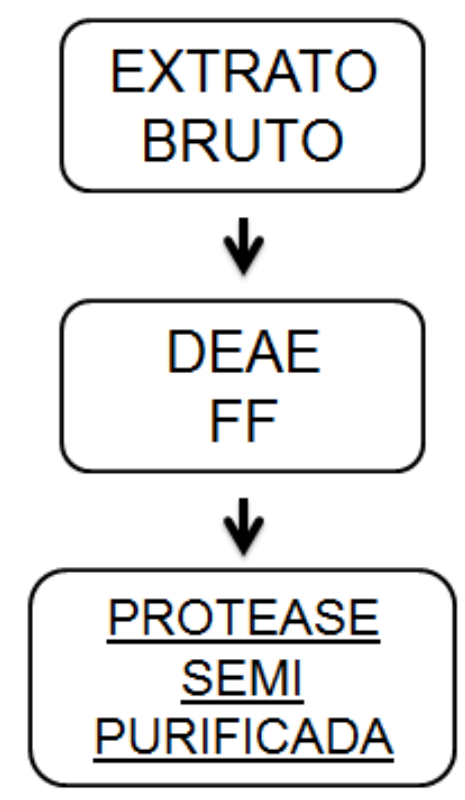

Figura 5. Fluxograma do processo de purificação de proteases presentes no extrato bruto após cultivo em meio liquido por 7 dias a $28^{\circ} \mathrm{C}$ e $120 \mathrm{rpm}$.

\subsection{ELETROFORESE EM GEL DE POLIACRILAMIDA}

$O$ perfil proteico das amostras foi analisado por eletroforese em gel de poliacrilamida $12 \%(\mathrm{v} / \mathrm{v})$ contendo SDS $0,1 \%(\mathrm{p} / \mathrm{v})$, sob condições desnaturantes foi realizado segundo Laemmli (105).

As amostras foram previamente precipitadas utilizando solução de ácido tricloroacético (TCA) $100 \%$ e incubadas por aproximadamente 12 horas a $4^{\circ} \mathrm{C}$. Em seguida a amostra foi submetida à centrifugação por 15 minutos a $14000 \mathrm{rpm} \mathrm{e} 4^{\circ} \mathrm{C}$, após o tempo o sobrenadante da amostra foi descartado, colocou-se a mesma quantidade de acetona padrão analítico gelada e centrifugou-se novamente nas mesmas condições já citadas. Este processo foi realizado três vezes. As amostras foram incubadas por 5 minutos à temperatura ambiente para secagem da acetona residual. Após esse tempo, as amostras foram ressuspensas com $20 \mu \mathrm{L}$ de tampão da amostra e fervidas por 7 minutos, para ocorrer a desnaturação das proteínas presentes na amostra. $\mathrm{O}$ volume de $15 \mu \mathrm{L}$ foi cuidadosamente adicionado aos poços 
presentes no gel e, após a corrida, as bandas de proteína foram reveladas por técnicas de coloração utilizando nitrato de prata. Foram utilizados os marcadores de massa molecular fosforilase b (97 kDa), soroalbumina bovina (66 kDa), ovoalbumina (45 kDa), anidrase carbônica (30 kDa), inibidor de tripsina (30,1 kDa) e alactalbumina (14,4 kDa) (Kit Low Molecular Weight Marker, GE Healthcare).

\subsection{COLORAÇÃO DO SDS-PAGE COM PRATA}

Ao final da corrida da amostra no gel de eletroforese, as bandas proteicas foram coradas segundo Blum e colaboradores (106). Primeiramente, o gel foi incubado (sob agitação) em solução fixadora (metanol 40\% (v/v), ácido acético 7\% $(\mathrm{v} / \mathrm{v}))$ por 1 hora. Em seguida, o gel foi lavado três vezes em solução etanol a $50 \%$ (v/v) durante 20 minutos cada, sob agitação. Após as lavagens, o gel foi incubado por 1 minuto em solução de tiossulfato de sódio 0,02\% (p/v), lavado três vezes com água destilada durante 10 segundos cada e incubado em solução de coloração (nitrato de prata 0,2\% (p/v), formaldeído 0,03\% (v/v) em $50 \mathrm{~mL}$ de água destilada) por 15 minutos sob agitação. Novamente, o gel foi lavado três vezes com água destilada, durante 10 segundos cada e submetido à solução reveladora (carbonato de sódio 6,0\% (p/v), tiossulfato de sódio 0,004\% (v/v), formaldeído 0,02\% (v/v) em $50 \mathrm{~mL}$ de água destilada). A reação foi interrompida com solução fixadora após o surgimento das bandas.

\subsection{ZIMOGRAMA}

Para averiguar a atividade da protease em gel de poliacrilamida, foi realizada a técnica de zimograma segundo Bischoff (107) através de gel de poliacrilamida 12\% ( $\mathrm{v} / \mathrm{v}$ ) como descrito no subitem 5.12 copolimerizado com solução de gelatina $0,2 \%$ $(\mathrm{p} / \mathrm{v})$ (Merck). As amostras foram preparadas de acordo com o subitem 5.12. Após a eletroforese, o gel foi incubado duas vezes (30 minutos cada vez) em solução Triton® X-100 1\% (v/v) à temperatura ambiente. Em seguida o gel foi lavado com água destilada e encubado em tampão Fosfato de sódio $0,1 \mathrm{M}$ pH 7,0 por 3 horas a 
$60^{\circ} \mathrm{C}$. Após o tempo de encubação o gel foi corado com solução de Coomassie brilliant blue R250 (Nuclear) e descorado com água destilada até o aparecimento das bandas

\subsection{CARACTERIZAÇÃO PARCIAL DA ENZIMA PARCIALMENTE PURIFICADA}

\subsubsection{Avaliação do pH ótimo para atividade proteolítica}

Foi realizado ensaio para verificar o $\mathrm{pH}$ ótimo de atividade proteolítica da amostra parcialmente purificada . O ensaio foi realizado conforme item 4.7 , segundo Cavello e colaboradores (69) nos pHs 5, 6, 7, 8 e 9.

\subsubsection{Avaliação da temperatura ótima para atividade proteolítica}

A temperatura ótima para atividade enzimática da amostra parcialmente purificada foi realizada segundo Cavello e colaboradores (69), conforme item 4.8, nas temperaturas $40^{\circ} \mathrm{C}, 50^{\circ} \mathrm{C}, 60^{\circ} \mathrm{C}, 70^{\circ} \mathrm{C}$ e $80^{\circ} \mathrm{C}$.

\subsubsection{Determinação da estabilidade térmica}

A estabilidade térmica da enzima foi determinada encubando-se amostra contendo a enzima parcialmente purificada a $60^{\circ} \mathrm{C}$ por 150 minutos. A atividade enzimática residual foi realizada a cada 30 minutos conforme Charney e Tomarelli (1947) (103). 


\subsection{TRIAGEM PARA APLICAÇÃO ENZIMÁTICA DA PROTEASE}

\subsubsection{Atividade queratinolítica}

Foi realizado ensaio para determinar se a enzima proteolítica parcialmente purificada possuía atividade queratinolítica. $O$ ensaio foi realizado segundo Sousa e colaboradores (108) com modificações. Foi colocado em tubo de centrifuga de $5 \mathrm{~mL}$, $20 \mathrm{mg}$ de azoqueratina (Sigma Aldrich, MO, USA), 3,8 mL de tampão tris-HCl 100 $\mathrm{mM}, \mathrm{pH} 7,8$ e $0,2 \mathrm{~mL}$ de amostra. Além disso, foi feito um branco do substrato, contendo $20 \mathrm{mg}$ de azoqueratina e 4,0 mL de tampão tris- $\mathrm{HCl} 100 \mathrm{mM}, \mathrm{pH}$ 7,8, e um branco da amostra contendo $4,0 \mathrm{~mL}$ de tampão e $0,2 \mathrm{~mL}$ de amostra. Todos os tubos foram incubados a $37^{\circ} \mathrm{C}$ por 1 hora e em seguida colocados a $4^{\circ} \mathrm{C}$ por 10 minutos. As amostras foram então centrifugadas por 8 minutos, $10000 \mathrm{~g} \mathrm{a} 4^{\circ} \mathrm{C}$ e 0 sobrenadante foi lido a $520 \mathrm{~nm}$ num espectrofotômetro. Um aumento de 0,1 na absorbância foi indicado com 1 unidade de atividade enzimática.

\subsubsection{Atividade colagenolítica}

O ensaio para atividade colagenolítica foi realizado segundo Rosso e colaboradores (109) com modificações. Como substrato foi utilizado Azocoll (Azo dye impregnated collagen - Sigma Aldrich). Suspendeu-se o Azocoll com tampão Tris-Hcl $0,05 \mathrm{M} \mathrm{pH} \mathrm{7,2} \mathrm{contendo} 1 \mathrm{mM}$ de $\mathrm{CaCl}_{2}$ até uma concentração final de 5 $\mathrm{mg} / \mathrm{mL}$. O ensaio foi realizado misturando-se $300 \mu \mathrm{L}$ de amostra semipurificada, 300 $\mu \mathrm{L}$ de tampão Tris-Hcl 0,05 M pH 7,2 contendo $1 \mathrm{mM}$ de $\mathrm{CaCl} 2$ e $540 \mu \mathrm{L}$ de suspensão de Azocoll em um microtubo de $5 \mathrm{~mL}$. Foi feito um branco do substrato contendo $600 \mu \mathrm{L}$ de tampão e $540 \mu \mathrm{L}$ de suspensão de azocoll e um branco da amostra contendo $840 \mu \mathrm{L}$ de tampão e $300 \mu \mathrm{L}$ de amostra. Todos os microtubos foram incubados a $37^{\circ} \mathrm{C}$ por 3 horas com rotação de $330 \mathrm{rpm}$, após o tempo os tubos foram centrifugados a $10000 \mathrm{~g}$ por 8 minutos resultando na parada da reação. A absorbância do sobrenadante foi lida a $520 \mathrm{~nm}$ usando espectrofotômetro. Uma unidade de atividade (UI) foi definida como a quantidade de enzima por ml que produziu um aumento na absorbância de 0,1 após 3 horas a $520 \mathrm{~nm}$. A coloração 
apresentada pelo branco da amostra e pelo branco do substrato foram diminuídas da absorbância apresentada no tubo teste.

\subsubsection{Atividade coagulante no leite}

A atividade coagulante foi determinada segundo Arima (8) com modificações. Preparou-se solução de leite em pó desnatado $10 \%(\mathrm{p} / \mathrm{v})$ reconstituído com solução de cloreto de cálcio $\left(\mathrm{CaCl}_{2}\right)$ 0,01M, encubou-se esta solução por 10 minutos a $35^{\circ} \mathrm{C}$. Após o tempo, adicionou-se 0,5 mL de amostra semipurificada, imediatamente após a adição de amostra iniciou-se a contagem do tempo rodando o tubo manualmente continuamente até visualizar as primeiras partículas de coagulo. Uma unidade de atividade coagulante (UAC) foi definida como a quantidade de enzima presente em 1 $\mathrm{mL}$ de amostra necessária para coagular $10 \mathrm{~mL}$ de substrato em 40 minutos.

\subsubsection{Atividade como removedor de manchas}

O teste para estudar a enzima como removedor de manchas foi feito segundo Vijayalakshmi e colaboradores (60) com modificações. Pedaços de pano de algodão branco $(5 \mathrm{~cm} \times 5 \mathrm{~cm})$ foram embebidos em sangue de carne de boi, café, suco de couve e molho de tomate. Após os pedaços de pano sujos secarem (overnight) os mesmos foram embebidos em solução de formaldeído $2 \%$ e em seguida lavou-se com agua para remover o excesso. Foi preparado solução de detergente em pó em concentração de $7 \mathrm{mg} / \mathrm{mL}$ (concentração geralmente utilizada em maquina de lavar) e ferveu-se essa solução por 15 minutos para inativar possíveis enzimas adicionadas a formulação. $\mathrm{O}$ tecido manchado foi encubado a $37^{\circ} \mathrm{C}$ em erlenmeyer contendo $20 \mathrm{~mL}$ de solução de detergente e $5 \mathrm{~mL}$ de amostra contendo enzima, com rotação de 150 rpm por 40 minutos. Após o tempo, cada pedaço foi lavado com agua e secou-se em estufa a $37^{\circ} \mathrm{C}$, o resultado foi analisado visualmente. Foram feitos ainda dois controles, um contendo apenas o tecido sujo e $25 \mathrm{~mL}$ de agua destilada e outro contendo $25 \mathrm{~mL}$ de solução de detergente em concentração de 7 $\mathrm{mg} / \mathrm{mL}$ para comparação. 


\subsubsection{Compatibilidade com detergentes comerciais}

A compatibilidade da enzima produzida pelo fungo endofítico com formulações de detergentes comerciais foi estudada segundo Banik e Prakash (64) utilizando três marcas de detergente (M1, M2 e M3). Para isso, o detergentes foram diluídos em concentração de $7 \mathrm{mg} / \mathrm{mL}$. Foi realizado tratamento térmico incubando-se 0 detergente a $100^{\circ} \mathrm{C}$ por 15 minutos para desativar enzimas possivelmente presentes nas formulações. Foi adicionado $1 \mathrm{~mL}$ de amostra contendo protease em $4 \mathrm{~mL}$ de solução de detergente, esta mistura foi encubada a $50^{\circ} \mathrm{C}$ por 1 hora e a atividade residual de protease foi determinada. Foi realizado um controle sem a presença de detergente, que teve sua atividade tomada como $100 \%$. 


\section{RESULTADOS E DISCUSSÃO}

\subsection{ISOLAMENTO DE FUNGOS ENDOFÍTICOS}

Foram isolados 58 fungos endofíticos a partir de 13 espécies distintas de folhas de plantas do cerrado, como mostra a Tabela 4.

Tabela 4 - Códigos atribuídos aos fungos endofíticos isolados e suas espécies hospedeiras.

\begin{tabular}{ll}
\hline \multicolumn{1}{c}{ Nome científico } & \multicolumn{1}{c}{ Fungos isolados } \\
\hline Sapindus saponária & Ssp Br; Ssp P; Ssp B \\
Calophys nigra & Morus \\
Eriotheca pubescens & CB01; CB02 \\
Ourátea hexasperma & EP01; EP02; EP03; EP04 \\
Dalbergia miscolobium & DM01; OH02; OH03; OH04; OH05 \\
Polteria torta & PT01; PT02; PT03 \\
Stryphnidendron & SADS01; SADS02 \\
adstringens & KC01; KC02; KCS \\
Kielmeyera coriacea & SL01; SLS \\
Solanum lycocarpum & PEQ01; PEQ02; PEQ03; PEQ04; PEQ05; PEQ06; PEQ07; \\
Caryocan brasiliensis & PEQ08; PEQ09; PEQ10; PEQ11; PEQ12 \\
Tabebuia ochracea & IPE01; IPE02; IPE03; IPE04; IPE05; IPE06 \\
Psidum ochracea & GOI01; GOI02; GOI03; GOI04; GOI05; GOI06; GOI07; \\
& GOI08; GOI09; GOI10; GOI11; GOI12; GOI13 \\
\hline
\end{tabular}

Segundo Tan e Zou (96) várias centenas de espécies de fungos endofíticos podem ser isoladas de uma única espécie de planta, portanto, o número de fungos isolados é variável, Vieira e colaboradores (110) isolaram da planta Ixora coccinea L., 530 fungos endofíticos pertencentes a seis gêneros: Curvularia, Fusarium, Guignardia, Pestalotiopsis, Phoma e Xylaria. Para isso foram utilizadas folhas de 10 plantas que estavam plantadas em de quatro diferentes cidades. Alguns estudos relatam números mais baixos de fungos endofíticos isolados, Correa (111) relata o isolamento de 4 fungos endofíticos vindos de folhas da espécie Palicourea 
marcgravii. Além destes, outros artigos tiveram números diferentes de isolamento de fungos por folha ou espécie de planta, Huang e colaboradores (112) isolaram 426 fungos endofíticos da planta Kadsura angustifólia, Nascimento e colaboradores (113) isolaram 156 fungos de 468 fragmentos da planta Calotropis procera, Jiang e colaboradores(114) isolaram 206 fungos endofíticos da planta Angelica sinensis.

Petrini (102) citou que a quantidade de fungos isolados pode ser influenciada pela utilização de diferentes meios de cultivo na hora de inocular a planta, o meio escolhido pode induzir aparecimento de espécies diferentes e de maiores ou menores quantidades de espécies. Azevedo (86) cita ainda que quando o isolamento de um grupo específico de microrganismos é desejado, podem ser usados meios altamente seletivos que permitam apenas o crescimento daquela espécie, além disso, variáveis como o local da coleta, a idade da planta utilizada para o isolamento e a época do ano que a colheita foi realizada pode ter influencia nos tipos e na quantidade de microrganismos que serão isolados daquela planta (86, $87,102)$, e ainda, uma das maiores dificuldades relacionadas aos fungos endofíticos é a de que eles podem não crescer ou crescer pouco na ausência de sua planta hospedeira (86). Esses fatores dificultam o processo de isolamento e a reprodutibilidade da quantidade e tipos de fungos isolados, por isso não é possível estimar uma quantidade mínima, máxima ou usual de fungos isolados de cada folha.

A Figura 6 mostra a diversidade na morfologia dos fungos isolados das plantas do cerrado, é possível ver que foram isolados fungos de diferentes morfologias, o que pode acarretar em novas espécies e vários metabólitos primários e secundários de interesse industrial a serem isolados a partir destes. 


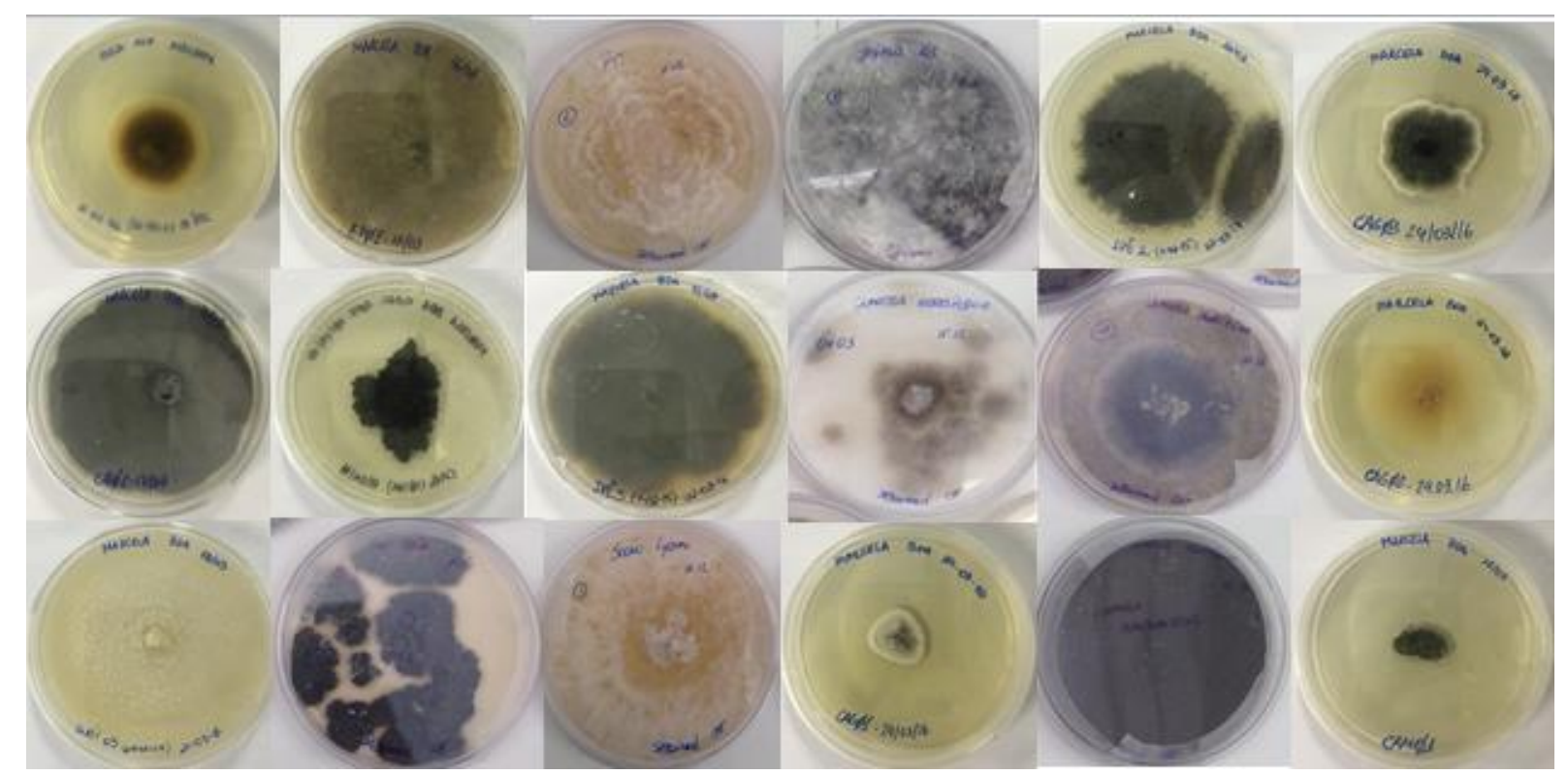

Figura 6. Fungos endofíticos isolados de folhas de plantas do cerrado após assepsia da superfície com hipoclorito de sódio $2 \%$, álcool $70 \%$ e água.

\subsection{TRIAGEM PARA A PRODUÇÃO DE PROTEASE}

\subsubsection{Avaliação qualitativa da produção de protease}

A visualização qualitativa da produção de protease extracelular foi verificada após 24 horas do inóculo do extrato bruto (EB) de cada um dos fungos endofíticos isolados em placa contendo ágar-leite. Dessa forma, foi possível avaliar neste trabalho a produção de protease extracelular pelos 58 fungos endofíticos isolados. Foram considerados produtores de proteases extracelulares os fungos que demonstraram halo translúcido e esbranquiçado ao redor do inoculo, independentemente do tamanho do mesmo.

Dentre os fungos analisados, 22 não apresentaram halo de produção proteolítica e 36 fungos (códigos apresentados na Tabela 5) apresentaram halo, demonstrando que $62,07 \%$ dos fungos isolados produziram protease extracelular que pode ser visualizada em meio contendo ágar e leite. Os halos produzidos pelos fungos podem ser vistos na Figura 7 . 
Tabela 5 - Códigos dos fungos endofíticos capazes de formar halo em meio sólido contendo ágarleite sugestivo da produção de proteases.

\begin{tabular}{ll}
\hline \multicolumn{1}{c}{$\begin{array}{c}\text { Nome científico da planta } \\
\text { de origem }\end{array}$} & Fungos produtores de halo de degradação de caseína \\
\hline $\begin{array}{l}\text { Sapindus saponária } \\
\text { Calophyllum brasiliense }\end{array}$ & $\mathrm{Br}$ \\
Eriotheca pubescens & $\mathrm{EP0} 0$ \\
Ourátea hexasperma & $\mathrm{OH} 01 ; \mathrm{OH} 03$; OH04; OH05 \\
Dalbergia miscolobium & DM01 \\
$\begin{array}{l}\text { Polteria torta } \\
\text { Stryphnidendron }\end{array}$ & PT01B; PT01P; PT02; PT03 \\
adstringens & SADS01; SADS02; SC01 \\
Kielmeyera coriacea & KC01; KC02 \\
Solanum lycocarpum & SSL01; SLSUP \\
Caryocan brasiliensis & PEQ01; PEQ02; PEQ03; PEQ04; PEQ05; PEQ06; PEQ08; \\
Tabebuia ochracea & PEQ10; PEQ12 \\
Psidum ochracea & IPE04; IPE 03; IPE06 \\
\hline
\end{tabular}

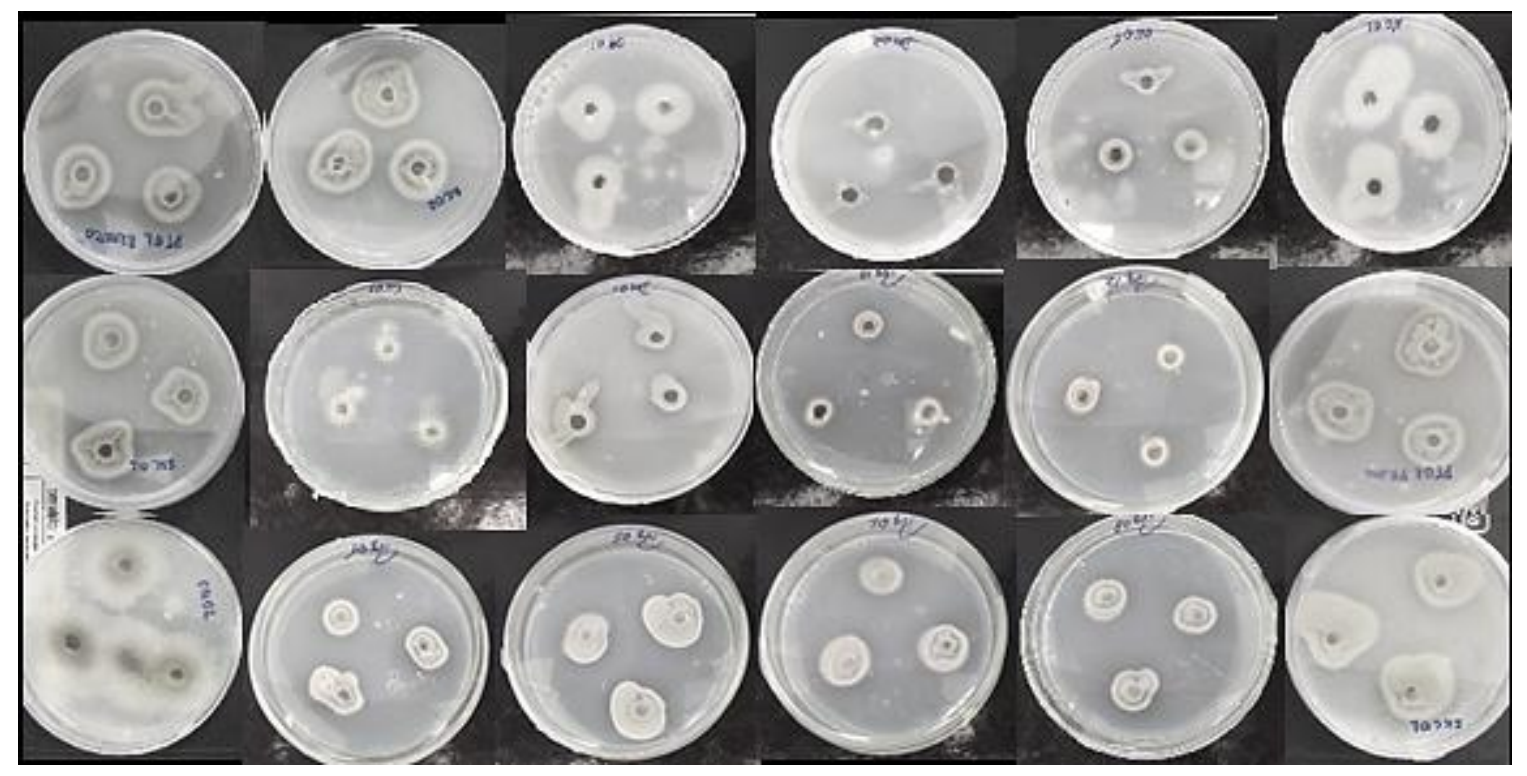

Figura 7. Halos produzidos pelos fungos endofíticos PT01B, KC02, BR, DM02, OH04, KC01, SSL01, OH05, DM01, PEQ10, PEQ12, PT01P, OH02, PEQ04, PEQ05, PEQ01, PEQ08 E SKL01, respectivamente. 
Rodarte e colaboradores (115) avaliaram a produção de protease por 144 microrganismos isolados do grão de café (Coffea arábica), dentre esses, 66 eram fungos filamentosos e $50 \%$ destes, foram capazes de produzir halos de proteases em meio ágar-leite.

Já foi reportado na literatura a produção de protease por fungos endofíticos, Borges e colaboradores (17) citaram o fungo Colletotrichum $s p$. isolado das plantas Cinnamomum iners e Camellia sinensis produtor de celulase, mananase, xilanase e protease. O mesmo autor também citou o fungo Phoma sp. Isolado de Garcinia cowa produtor de mananase, celulase e protease e o fungo do gênero Xylaria sp. Isolado da planta Trichilla connaroides produtor de celulase, mananase, protease e xilanase.

Orlandelli e colaboradores (116) testaram 98 fungos endofíticos isolados de folhas da planta $P$. hispidum para produção de protease utilizando meio contendo ágar, gelatina e leite, destes, $28(28,57 \%)$ apresentaram halo indicando a produção proteolítica. Souza (117) analisou 17 diferentes espécies de fungos filamentosos isolados do solo do cerrado brasileiro para produção de proteases utilizando placas contendo ágar e leite. Das 17 espécies analisadas, 9 apresentaram halo (52,94\%).

\subsubsection{Avaliação quantitativa da produção de protease}

Os 36 fungos que apresentaram halo para produção de protease foram submetidos a ensaio enzimático para quantificar a produção da enzima de interesse. Como pode ser visualizado na Figura 8 os fungos com maior produção de protease foram: BR, OH03, PT02, PEQ03 e KC01. 


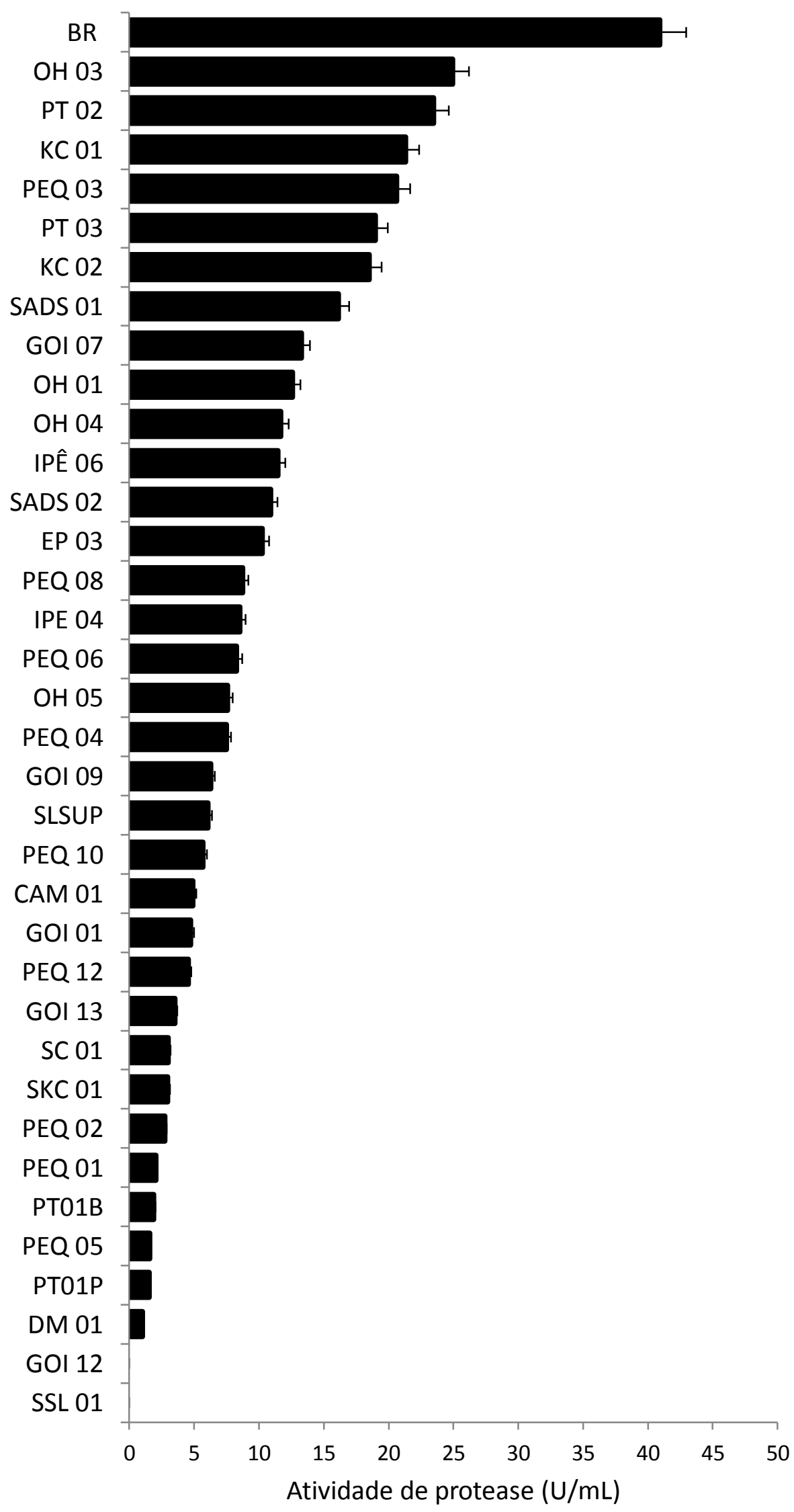

Figura 8. Atividade proteolítica de fungos endofíticos isolados de folhas do cerrado brasileiro. As barras de erro correspondem a um intervalo de confiança de $95 \%$ nos valores obtidos. 
Neste estudo o melhor produtor de protease, entre os fungos isolados e utilizando azocaseína como substrato, foi o fungo codificado como BR com atividade enzimática de $41 \mathrm{UI} / \mathrm{mL}$, o segundo produtor foi o fungo $\mathrm{OH} 03 \mathrm{com} \mathrm{24,76} \mathrm{UI/mL}$ seguido do fungo PT02 com atividade de 23,47 Ul/mL, KC01 (21,03 Ul/mL) e PEQ03 $(20,60 \mathrm{Ul} / \mathrm{mL})$, estes resultados estão em acordo com a literatura, confirmando que os fungos endofíticos isolados são bons produtores de protease. Novelli e colaboradores (118) estudaram proteases vindas de $A$. oryzae com atividade de 5,10 $\mathrm{UI} / \mathrm{mL}$, Aspergullus brasiliensis com atividade de $11,89 \mathrm{UI} / \mathrm{mL}$ e Aspergillus flavipes com atividade de $27,78 \mathrm{UI} / \mathrm{mL}$. Souza e colaboradores (80) investigaram a produção de proteases pelo fungo Aspergillus foetidus, o fungo mostrou atividade enzimática proteolítica de 55,67 Ul/mL.

Além destes, Nascimento e colaboradores quantificaram proteases produzidas por fungos filamentosos isolados do fruto de Macaúba (Acrocomia aculeata), dos 19 fungos analisados, 16 produziram proteases onde 0 melhor produtor foi o M27 com 5,417 U/mL (119). Chaud e colaboradores demonstraram que Rhodotorula mucilaginosa produziu protease extracelular com atividade de $33,36 \mathrm{UI} / \mathrm{mL}$ (120). Os cinco melhores produtores de protease foram escolhidos para continuar o trabalho.

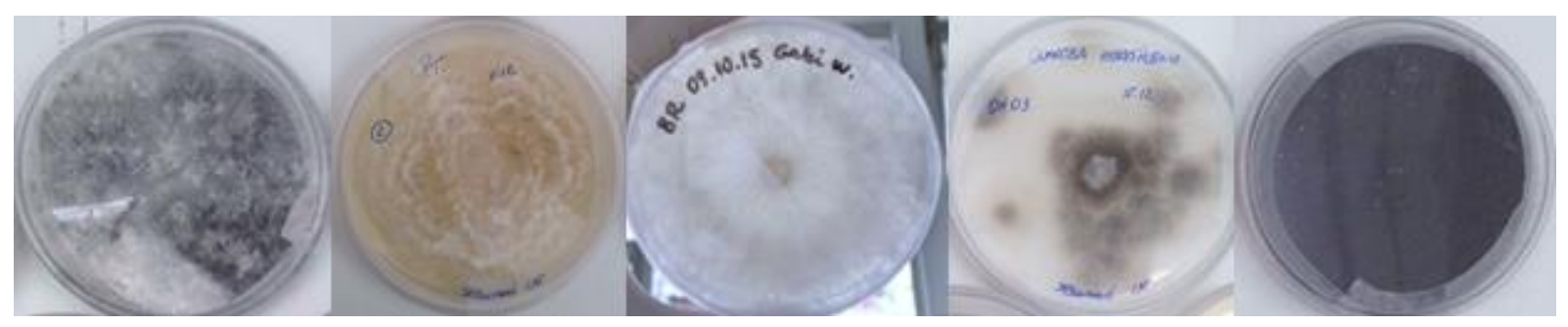

Figura 9. Cinco fungos produtores de protease selecionados neste trabalho: $\mathrm{KC01}, \mathrm{PTO2}, \mathrm{BR}, \mathrm{OH} 03$ e PEQ03

\subsection{AVALIAÇÃO DA INFLUENCIA DO pH NA ATIVIDADE ENZIMATICA}


Considerando a relevância da caracterização bioquímica para a aplicação industrial, foi avaliado o $\mathrm{pH}$ ótimo para as proteases extracelulares presentes no extrato bruto dos 5 melhores produtores anteriormente selecionados. As proteases produzidas pelo fungo $\mathrm{BR}$ e PEQ03 obtiveram a maior atividade enzimática em $\mathrm{pH}$ 7,0. A proteases expressas pelo fungo $\mathrm{OH} 03$ mostraram alta atividade em $\mathrm{pH} 6,0$. A protease produzida pelo fungo $\mathrm{KC0} 1$ mostrou maior atividade proteolítica em $\mathrm{pH} 6,0$ e 9,0, e a protease excretada pelo fungo PT02 mostrou atividade enzimática constante entre nos valores de pH 6,0 e 8,0 (Figura 10). 

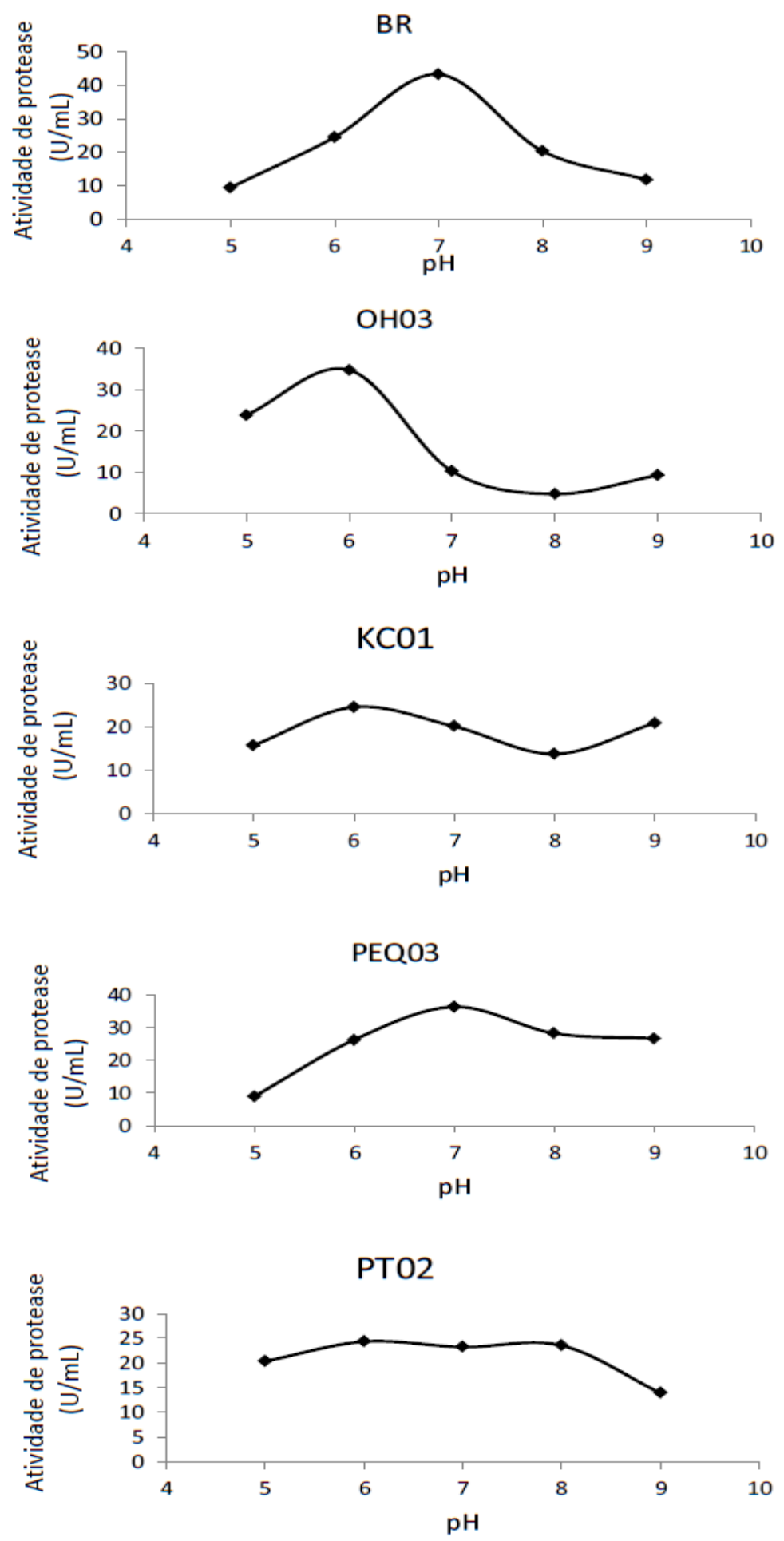

Figura 10. Efeito do $\mathrm{pH}$ na atividade proteolítica dos fungos endofíticos $\mathrm{BR}, \mathrm{OH} 03, \mathrm{PEQ} 03, \mathrm{KCO}$ e PT02 a $55^{\circ} \mathrm{C}$.

Os resultados obtidos estão em acordo com a literatura onde Dadshahi e colaboradores purificaram uma protease produzida por Penaeus vannamei com 
máxima atividade em $\mathrm{pH} 7,0$ (12). Novelli e colaboradores demonstraram proteases vindas de $A$. niger com pH ótimo 8,0 e protease produzida por Aspergillus brasiliensis com pH ótimo 7,0 (118). Anitha e Palanivelu estudaram protease queratinolítica excretada por $A$. parasíticus com pH ótimo 7,0 (121), Hayet e colaboradores purificaram protease de Sardinella aurita com pH ótimo 8,0 (122), Rasovic e colaboradores estudaram protease produzida por Ficus Carica com pH ótimo 8,5 (123).

Além destes, Shankar e colaboradores caracterizaram protease de Beauveria sp. Com pH ótimo 9,0 (124), Li e colaboradores caracterizaram protease extracelular produzida por Clonostachys rósea com pH ótimo 9.0-10,0 (125). Estes resultados abrem um grande leque de possibilidades de aplicação industrial, pois é comum a utilização de proteases neutras e alcalinas na indústria de detergente $(59,60)$, indústria de processamento de couro (53), indústria alimentícia $(9,36)$, entre outras.

\subsection{AVALIAÇÃO DA INFLUENCIA DA TEMPERATURA NA ATIVIDADE ENZIMÁTICA}

A temperatura ótima de atividade de protease para cada um dos 5 produtores selecionados nestes trabalho foi realizada no $\mathrm{pH}$ ótimo de cada fungo (para fungos $\mathrm{BR}$ e PEQ03 o teste foi realizado em pH 7,0; para fungos $\mathrm{OH} 03$ e PT02 em pH 6,0 e para $\mathrm{KC01}$ em pH 8,0). Conforme se pode visualizar na Figura 11, a temperatura óptima de atividade de protease dos fungos $\mathrm{OH} 03$, PEQ03, KC01 e PT02 foi de $50^{\circ} \mathrm{C}$, e para o fungo $\mathrm{BR}$ foi de $60^{\circ} \mathrm{C}$. 

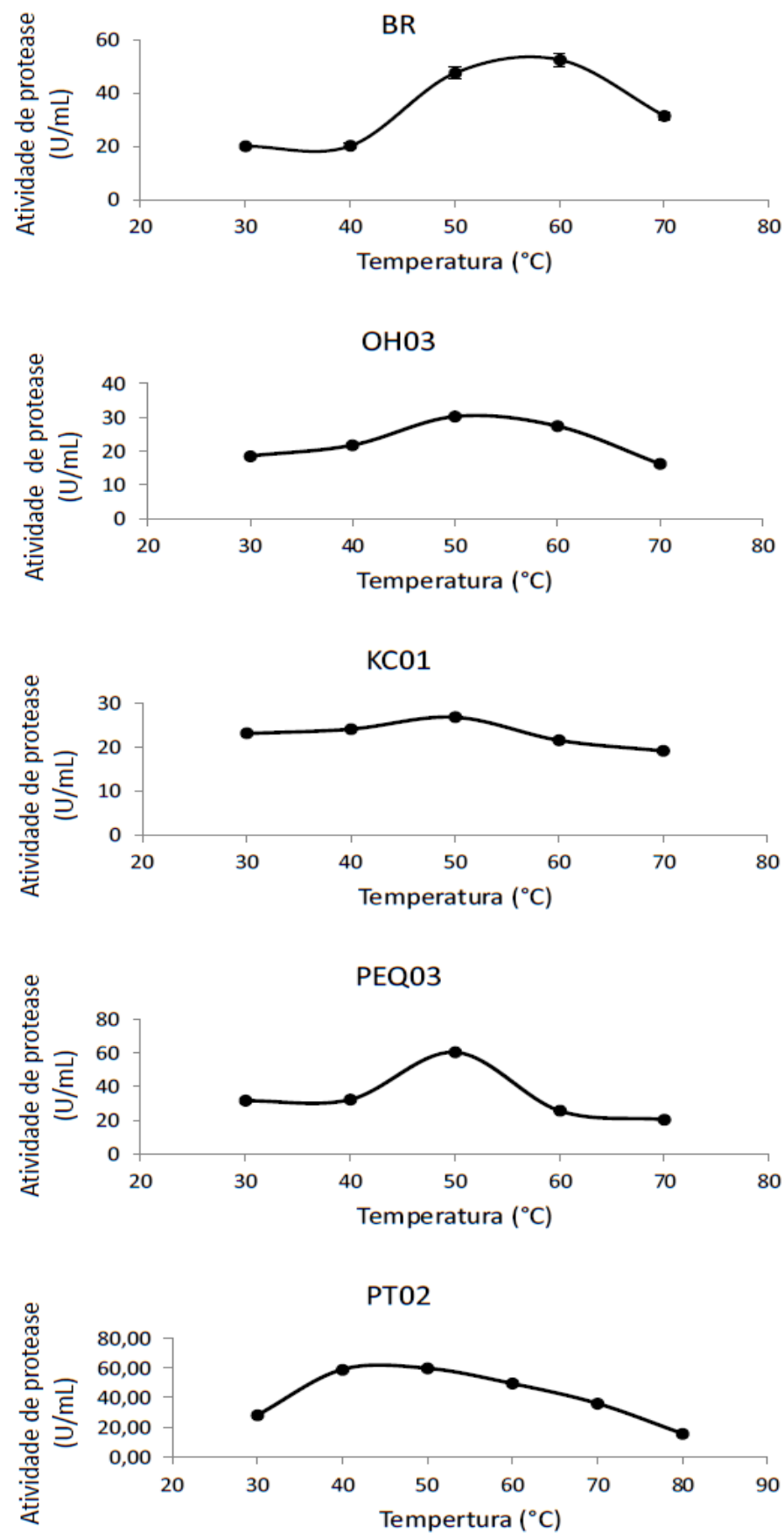

Figura 11. Efeito da temperatura na atividade proteolítica dos fungos endofíticos $\mathrm{BR}, \mathrm{OH} 03, \mathrm{PEQ} 03$, $\mathrm{KC} 01$ e PT02. As temperaturas de incubação variaram de $30^{\circ} \mathrm{C}$ a $80^{\circ} \mathrm{C}$. Para os fungos $\mathrm{OH} 03$, PEQ03, KC01 e PT02 foi de $50^{\circ} \mathrm{C}$, e para o fungo BR foi de $60^{\circ} \mathrm{C}$.

Estas temperaturas ótimas foram também relatadas por Li e colaboradores com protease produzida por Cellumonas bogoriensis $\left(60^{\circ} \mathrm{C}\right)$ (126), Rasovic e colaboradores com protease produzida por Ficus carica $\left(60^{\circ} \mathrm{C}\right)(123)$, Hayet e colaboradores com serina protease excretada por Sardinella aurita $\left(60^{\circ} \mathrm{C}\right)(122)$, e 
ainda, Anitha e Palanivelu com protease queratinolítica produzida por A. parasiticus $\left(50^{\circ} \mathrm{C}\right)$.

Foram relatadas ainda temperaturas ótima de $50^{\circ} \mathrm{C}$ para protease produzida por A. orizae examinada por Salihi e colaboradores (127), de $50^{\circ} \mathrm{C}$ para protease produzida pela alga marinha Rhodotorula mucilaginosa $L 7$ caracterizada por Lario e colaboradores (128) e ainda, temperatura ótima de $50^{\circ} \mathrm{C}$ foi relatada por Jankiewicz e colaboradores para protease excretada pela bactéria Tenotrophomonas maltophilia N4. Ferrareze e colaboradores purificaram uma serina protease de $B$. subtilis FTC02PR1 com temperatura ótima de $60^{\circ} \mathrm{C}(129)$.

O fungo codificado como BR (Figura 12) foi escolhido para continuar o presente trabalho, pois este apresentou a produção de protease mais elevada, além de temperatura ótima e pH ótimo de atividade enzimática compatíveis com aplicação em muitas industrias. De acordo com o ensaio de $\mathrm{pH}$ e temperatura ótima para atividade enzimática, os fungos KC01 e PT02 também demonstraram potencial para aplicação industrial, porém o crescimento do fungo BR em placa foi repetitivo, apresentando maior segurança para os experimentos futuros.

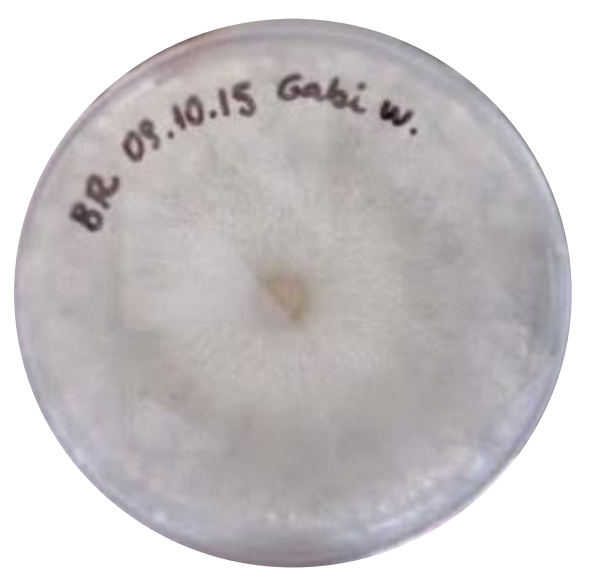

Figura 12. Fungo BR crescido em placa de Petri contendo meio Sabouraud-Dextrose (Himedia)

\subsection{AVALIAÇÃO DA INFLUENCIA DA FONTE DE NITROGENIO NA PRODUÇAO DE PROTEASES}

Sabe-se que a melhoria na produção de proteases por microrganismos é alvo de muitos estudos (130), pois cada cepa de microrganismo possui uma necessidade 
específica para aumentar a produção de enzimas. As proteases geralmente são produzidas durante a fase estacionária e, portanto, muitas vezes a fonte de carbono e de nitrogênio exerce efeitos reguladores da síntese da enzima $(31,131)$. Muitos estudos utilizam extrato de levedura e peptona como fontes de nitrogênio para produção extracelular de protease, por isso estas foram as fontes escolhidas para este experimento $(132,133)$. Estudos avaliam a indução da produção de enzimas proteolíticas utilizando glicose juntamente com a fonte de nitrogênio tais como extrato de levedura ou peptona (134).

Com base nessas considerações, foi realizado experimento para averiguar a melhor fonte de nitrogênio para a produção de protease utilizando fontes complexas de nitrogênio (peptona e extrato de levedura) e glicose como fonte de carbono pelo fungo BR, eleito o melhor produtor de protease dentre os fungos endofíticos isolados, como pode ser observado na Figura 13.

O fungo endofítico foi capaz de crescer em todos os meios utilizados neste trabalho, porém, o fungo BR produziu 48,45 Ul/mL de proteases em meio liquido quando foi utilizado peptona, extrato de levedura e glicose como fonte de carbono e nitrogênio, este valor supera o obtido quando se utilizou apenas peptona $(17,85)$, apenas extrato de levedura $(28,93)$ e com as fontes peptona e extrato de levedura combinadas sem glicose $(39,8)$.

Segundo Costa e colaboradores (135) a glicose é uma fonte essencial de fornecimento de carbono para a produção de moléculas tais como polissacarídeos, proteínas e lipídios. O meio MMPLG provavelmente induziu o fungo a produzir maiores quantidades de protease porque era o único dos quatro meios que estava suplementado com glicose e o único, portanto, que possuía uma fonte de carbono livre, induzindo assim o aumento da biomassa fungica. e consequentemente maior atividade enzimática.

Segundo Haddar e colaboradores (134) a produção de enzimas proteolíticas depende da concentração e disponibilidade de carbono e nitrogênio no meio de cultivo, esta disponibilidade e concentração regulam a síntese de protease, a capacidade de utilizar certa fonte de carbono ou de nitrogênio é diferente para cada microrganismo, os fungos filamentosos, como o BR, podem utilizar uma grande variedade de substratos para o seu crescimento, além disso, cada microrganismo ou 
cepa tem suas próprias condições individuais para produção máxima de enzima (136).

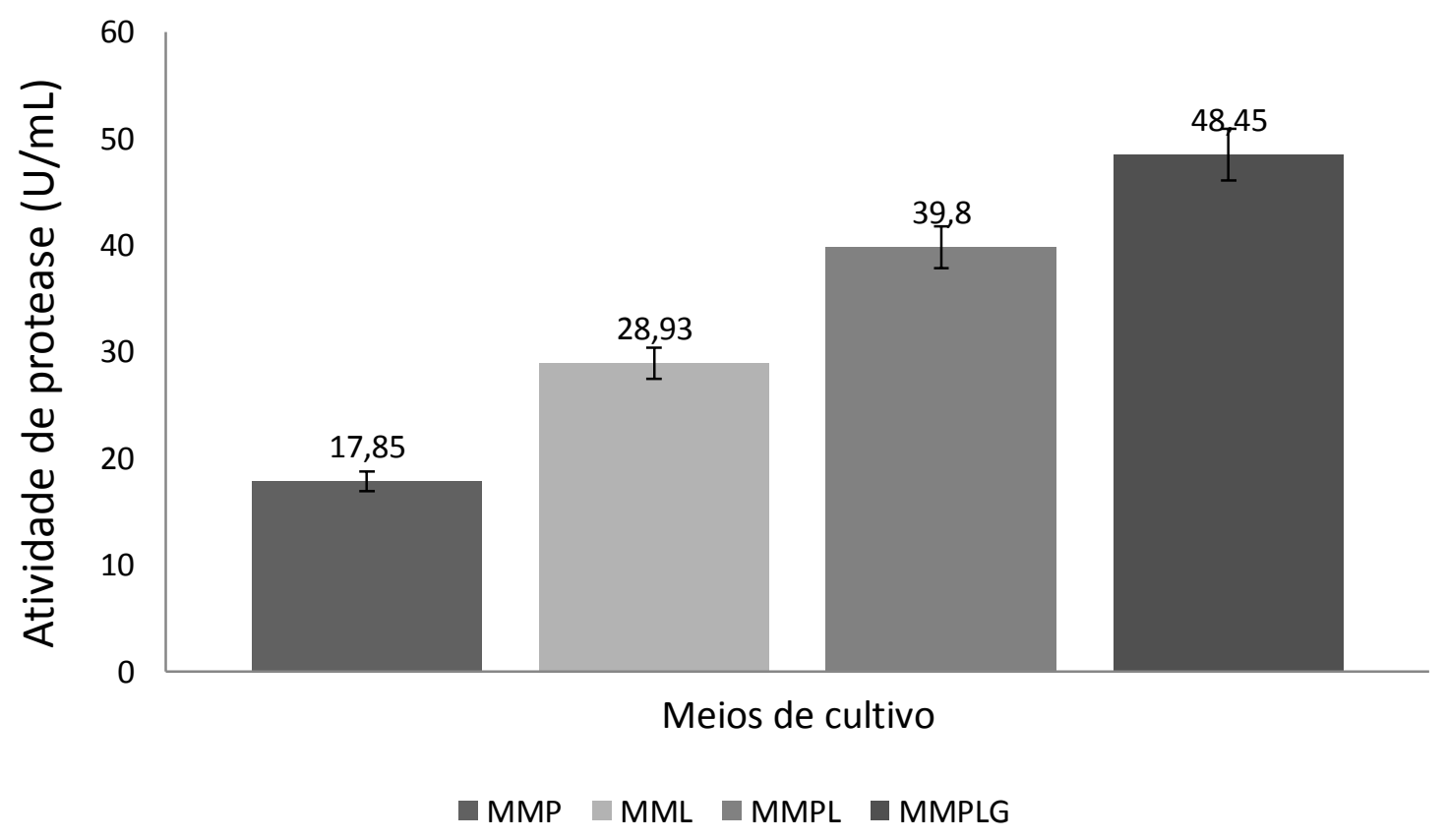

Figura 13. Produção de protease pelo fungo $B R$ em diferentes fontes de nitrogênio: meio mínimo e peptona (MMP); meio mínimo e extrato de levedura (MML); meio mínimo, peptona e extrato de levedura (MMPL); meio mínimo, peptona, extrato de levedura e glicose (MMPLG). Condições de cultivo: $28^{\circ} \mathrm{C}, 120 \mathrm{rpm}, 7$ dias. As barras de erro representam $95 \%$ dos limites de confiança para os resultados obtidos.

Patel e colaboradores (132) estudaram a atividade proteolítica produzida por uma cepa de Bacillus sp. em vários meios, o meio que mostrou melhor atividade proteolítica continha cas-aminoácidos, seguido de meio contendo gelatina, meio apenas com peptona, meio com peptona e extrato de levedura e meio com extrato de levedura e peptona de caseína. Haji e colaboradores (130) estudaram a produção de proteases por Aspergillus clavatus utilizando 2 fontes de nitrogênio inorgânicos (nitrato de sódio e sulfato de amônia) e 4 fontes orgânicas (peptona, extrato de levedura, caseína e uréia) e a melhor fonte de nitrogênio foi uma combinação entre extrato de levedura, peptona e caseína. Anandan e colaboradores 
(137) relataram que combinação entre glicose, peptona e nitrato de amônio possui influência positiva sobre a produção de proteases por $A$. tamarii.

Além destes, outros artigos também descrevem peptona, extrato de levedura e glicose, em combinações ou separadamente, como fontes que influenciam positivamente a produção de protease for fungos filamentosos como, por exemplo, Sousa (80). Malathi e colaboradores (138) demonstraram extrato de levedura como uma das melhores fontes de nitrogênio para produção de protease por $A$. flavus.

\subsection{CURVA DE CRESCIMETO E PARÂMETROS CINÉTICOS}

Após a escolha do melhor meio de produção de protease foi realizada curva de crescimento e foram observados os principais parâmetros cinéticos para conhecer o padrão de produção da enzima de interesse pelo fungo endofítico BR. O experimento foi realizado inoculando-se o fungo no meio de cultivo e analisando-se diariamente a atividade enzimática, quantidade de proteína, $\mathrm{o} \mathrm{pH}$ do meio e a biomassa fúngica durante 20 dias. A curva elucidou o dia em que ocorre a produção máxima de protease pelo fungo, o rendimento e alguns parâmetros cinéticos.

A Figura 14A mostra que o pH do meio não sofreu alteração durante todo 0 experimento e que a cinética de crescimento do fungo foi comum, mostrando uma fase de crescimento, fase estacionária e fase de declínio.

Na figura Figura 14. (A) Biomassa $(\bullet)$ e $\mathrm{pH}(\boldsymbol{\Delta})$ em meio MMPLG durante cultivo submerso a $28^{\circ} \mathrm{C}$ a $120 \mathrm{rpm}$. (B) Atividade enzimática $(\bullet)$ e glicose $(\boldsymbol{\Delta})$ em meio de cultivo MMPLG., é possível ver que a produção de protease inicia-se após 48 horas de cultivo e tem sua máxima produção em 432 horas $(66,40 \mathrm{UI} / \mathrm{mL})$, porém, o tempo de cultivo escolhido foi de 192 horas, quando a atividade proteolítica é de 41,40 Ul/mL, pois visando a purificação enzimática considera-se o melhor momento para cessar a fermentação, aquele em que o fungo possui a maior atividade específica, e, em 432 horas a atividade específica foi de 0,61, enquanto em 192 horas foi de 0,94. Além disso, o rendimento $\left(Y_{p / x}\right)$ foi melhor em 192 horas $(6,16)$, quando comparado com 432 horas $(5,82)$. 
Ainda na mesma Figura é possível ver que a glicose adicionada ao meio foi praticamente toda consumida dentro do período de 48 horas (3,63 - 0,25 g/L), esse comportamento também foi observado por Souza (2015) na produção de protease pelo fungo $A$. foetidus, em meio adicionado de glicose indicando que o fungo começou a produzir protease quando esta acabou (117). Provavelmente o fungo BR só iniciou a produção de protease para hidrolisar componentes presentes no meio depois de se esgotar a glicose, fonte de carbono simples. Além disso, segundo Haddar e (134) colaboradores a presença de altas quantidades de glicose no meio de cultivo pode desencadear uma repressão catabólica no microrganismo que produz protease.
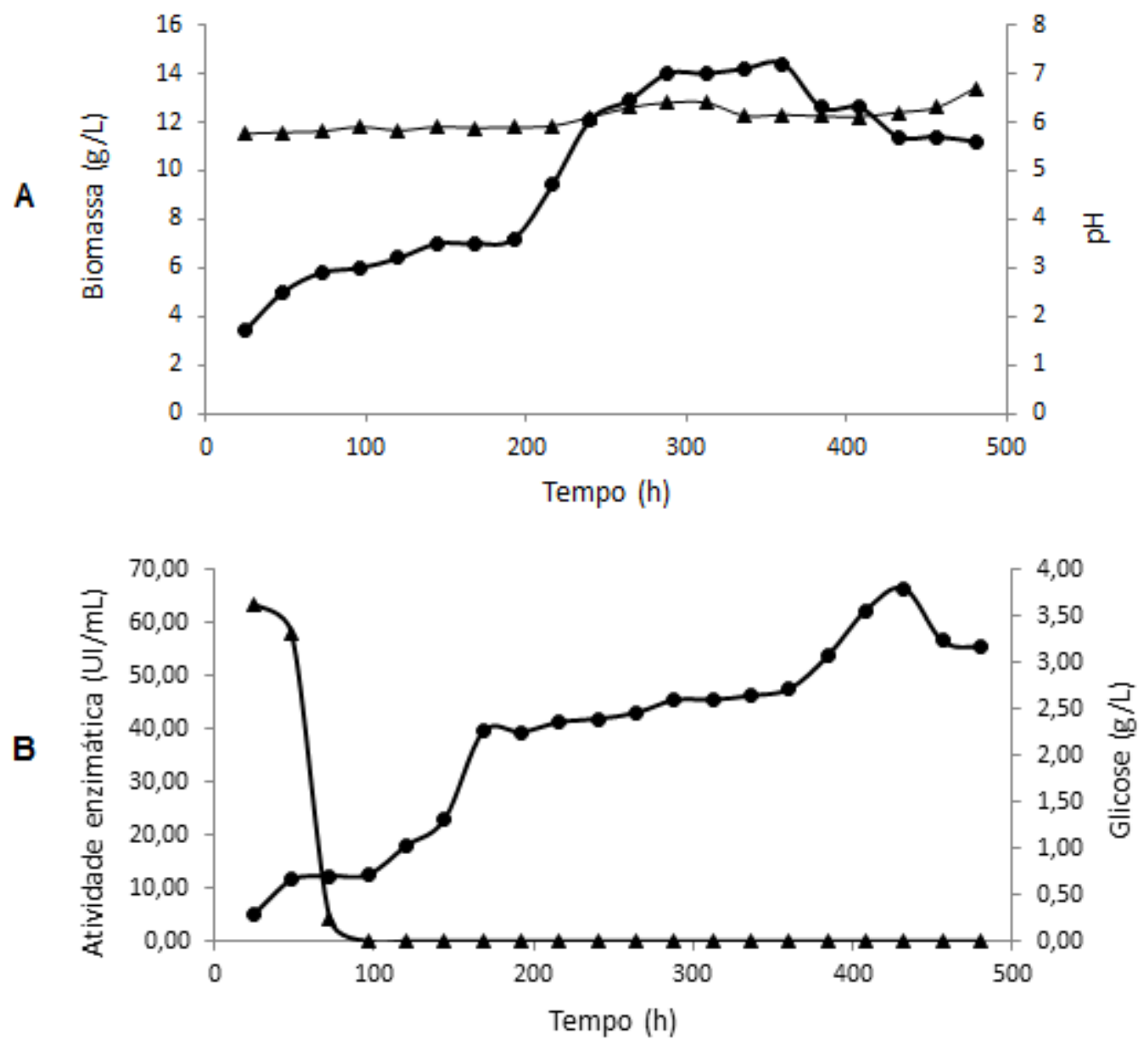

Figura 14. (A) Biomassa (•) e pH ( $\mathbf{\Delta})$ em meio MMPLG durante cultivo submerso a $28^{\circ} \mathrm{C}$ a 120 rpm. (B) Atividade enzimática $(\bullet)$ e glicose $(\boldsymbol{\Delta})$ em meio de cultivo MMPLG. 
Os resultados da cinética de crescimento e cinética enzimática do fungo em meio MMPLG podem ser visualizados na Tabela 6. O fungo apresentou a melhor velocidade específica de crescimento $\left(\mu_{\operatorname{máx}}=0,011 \mathrm{~h}^{-1}\right)$ em 192 horas, e o maior fator de conversão de biomassa em enzima $\left(Y_{E / X}=5820 \quad \mathrm{U} / \mathrm{g}_{\mathrm{x}}\right)$ em 432 horas de crescimento. A produtividade especifica em enzima foi maior em 48 horas $\left(\mathrm{Y}_{\mathrm{E} \text {,máx }}=\right.$ $\left.0,011 \mathrm{~h}^{-1}\right)$.

Tabela 6. Parâmetros cinéticos principais da produção de enzima pelo fungo endofítico BR em meio MMPLG, $28^{\circ} \mathrm{C}, 120 \mathrm{rpm}$.

\begin{tabular}{llll}
\hline Parâmetros & Símbolo & Tempo & Valor \\
\hline Velocidade específica de crescimento & $\mu_{\text {máx }}$ & 192 horas & $0,011 \mathrm{~h}^{-1}$ \\
Produtividade específica em enzima & $\mathrm{Y}_{\mathrm{E}, \text { máx }}$ & 48 horas & $48 \mathrm{U} / \mathrm{g}_{\mathrm{x}} \cdot \mathrm{h}$ \\
$\begin{array}{l}\text { Fator de conversão de biomassa em } \\
\text { enzima }\end{array}$ & $\mathrm{Y}_{\mathrm{E} / \mathrm{X}}$ & 432 horas & $5820 \mathrm{U} / \mathrm{g}_{\mathrm{x}}$ \\
\hline
\end{tabular}

Souza (117) encontrou $\mu_{\operatorname{máx}}=0,12 \mathrm{~h}^{-1}, \mathrm{Y}_{\mathrm{E} / \mathrm{X}}=1246 \mathrm{U} / \mathrm{g}_{\mathrm{x}}$ e $\mathrm{Y}_{\mathrm{E} \text {,máx }}=14,9 \mathrm{U} / \mathrm{g}_{\mathrm{x}} \cdot \mathrm{h}$ para o fungo $A$. foetidus em meio contendo peptona, caseína, extrato de levedura e caldo Sabouraud-dextrose. Estes valores são bastante específicos para cada fungo e para a produção da enzima de interesse por aquele fungo naquele meio especifico. Souza (117) demonstra ainda diferentes valores dos parâmetros cinéticos com o mesmo fungo em dois meios diferentes.

\subsection{PURIFICAÇÃO ENZIMÁTICA}

\subsubsection{Processo de purificação}

\section{- Cromatografia em coluna de troca iônica Hitrap DEAE FF}

O extrato bruto obtido foi liofilizado e submetido à cromatografia de troca iônica em coluna Sepharose DEAE de fluxo rápido (FF). Esta coluna é trocadora de ânions e atua através do grupo funcional dietilaminoetil. 
Primeiramente, foi aplicado na coluna de troca iônica 1,0 $\mathrm{mL}$ do extrato bruto liofilizado, contendo $188,3 \mu \mathrm{g} / \mathrm{mL}$ de proteína, com atividade enzimática de $70,54 \mathrm{UI} / \mathrm{mL}$. O cromatograma apresentou 2 picos, um antes do gradiente de $\mathrm{NaCl}$ e dois durante a formação do gradiente de $\mathrm{NaCl}$. Foram realizados ensaios de atividade enzimática em todos os picos presentes no cromatograma e a atividade enzimática de protease foi identificada no pico 1 (frações 4 e 5), como pode ser visto na Figura 15.

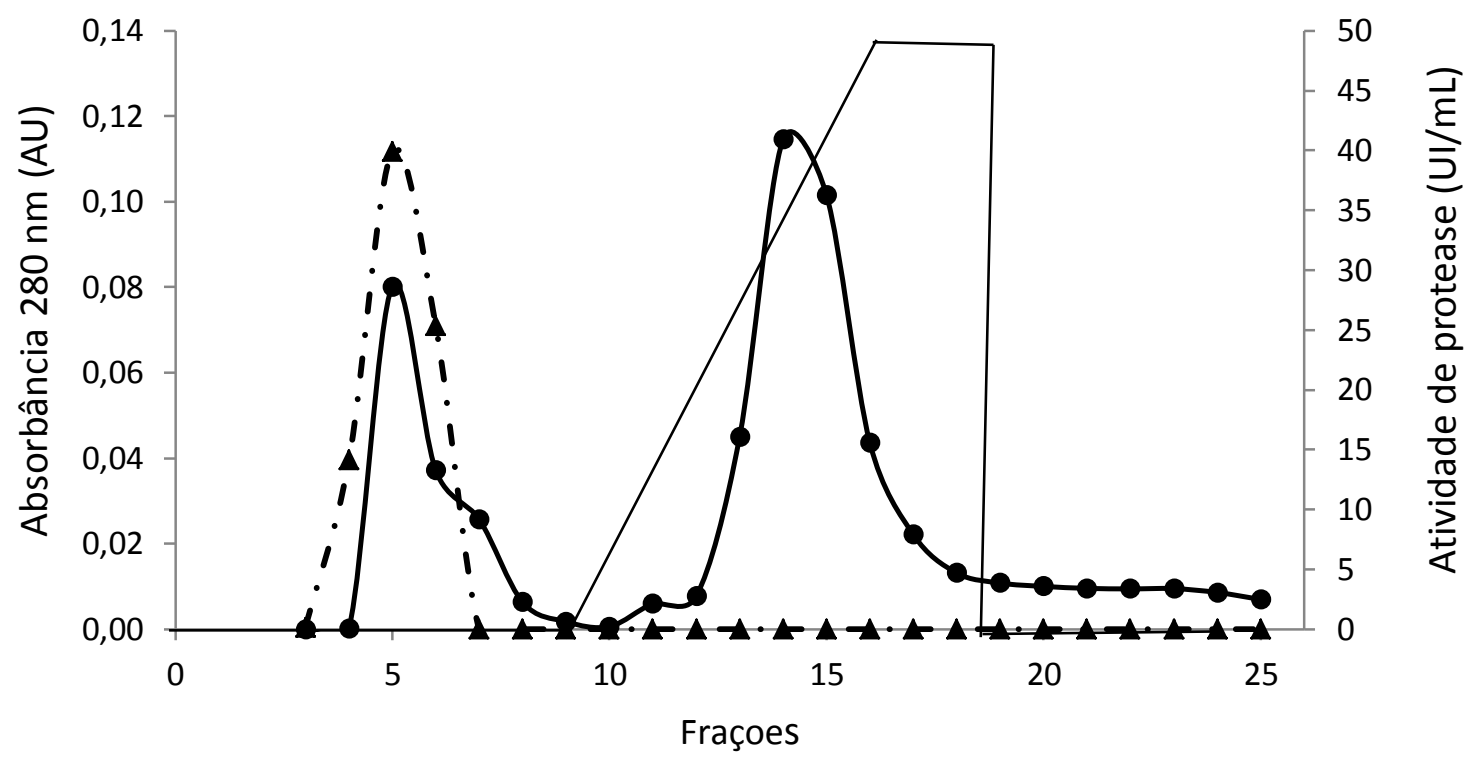

Figura 15. Cromatograma da purificação de protease utilizando cromatografia em coluna de troca iônica DEAE FF, mostrando atividade enzimática $(\boldsymbol{\Delta})$, proteína $(\bullet)$ e gradiente de $\mathrm{NaCl}(-)$. A amostra foi eluída com tampão fosfato de sódio $0,1 \mathrm{M} \mathrm{pH} 7,0$, com fluxo de $0,300 \mathrm{~mL} / \mathrm{min}$. Foi utilizado tampão

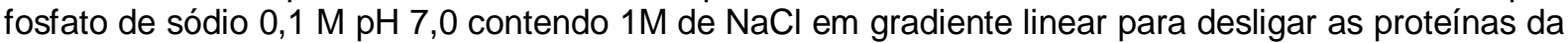
coluna. Equipamento utilizado: AKTA Pure system (GE healthcare biosciences, uppsala, Suíça).

A tabela abaixo (Tabela 7) mostra um resumo deste passo da purificação. A enzima foi purificada 3,66 vezes e apresentou uma atividade específica de 1375,47 Ul/mg de proteína.

Tabela 7. Purificação da protease produzida pelo fungo endofítico BR

\begin{tabular}{ccccc}
\hline Frações & $\begin{array}{c}\text { Proteína } \\
(\mathrm{mg} / \mathrm{mL})\end{array}$ & $\begin{array}{c}\text { Atividade } \\
(\mathrm{Ul} / \mathrm{mL})\end{array}$ & $\begin{array}{c}\text { Atividade } \\
\text { específica }(\mathrm{Ul} / \mathrm{mg})\end{array}$ & $\begin{array}{c}\text { Fator de } \\
\text { purificação }\end{array}$ \\
\hline Extrato Bruto & 0,188 & 70,54 & 375,21 & 1,00 \\
DEAE & 0,042 & 57,77 & 1375,47 & 3,66 \\
\hline
\end{tabular}


O pico 1 foi analisado por eletroforese em SDS-PAGE (Figura 16A), onde pode-se comparar a quantidade de proteínas no extrato bruto e na amostra semipurificada pela coluna DEAE FF. É visível uma grande diminuição na quantidade de bandas proteicas, a amostra semipurificada apresentou duas bandas proteicas principais de 55,27 kDa e 23,01 kDa. Para confirmar a presença da protease no gel foi realizado um zimograma (Figura 16B), a enzima proteolítica digeriu o substrato gelatina presente no gel, que pode ser visto como uma banda clara, confirmando que a enzima proteolítica é a que aparece no SDS PAGE com tamanho próximo a $55,27 \mathrm{kDa}$. Vishwanatha e colaboradores (139) utilizaram gel copolimerizado com gelatina para visualização da atividade proteolítica em zimograma, Fry e colaboradores (140) também utilizaram zimograma copolimerizado com gelatina.

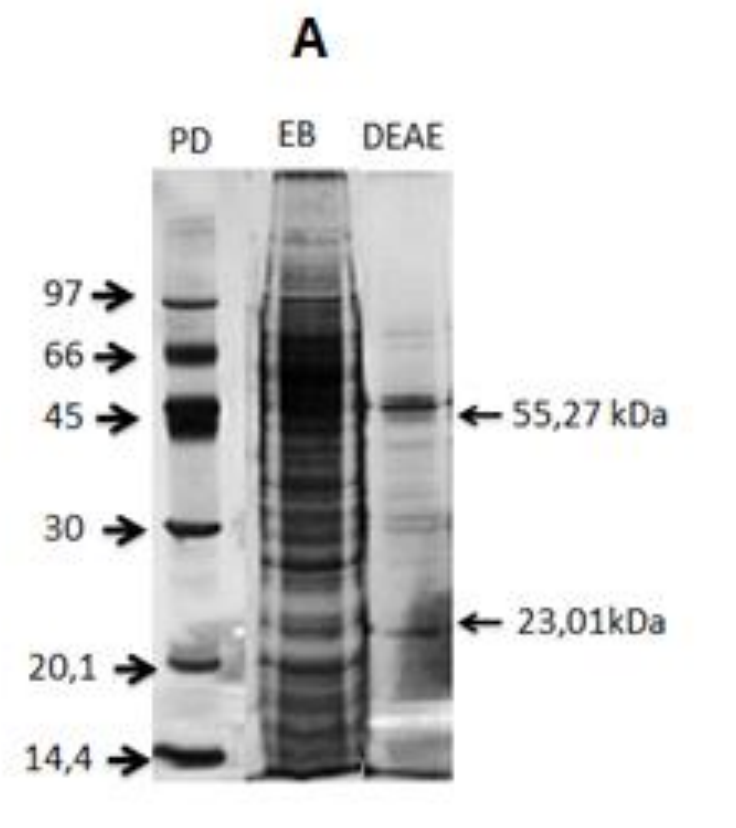

B

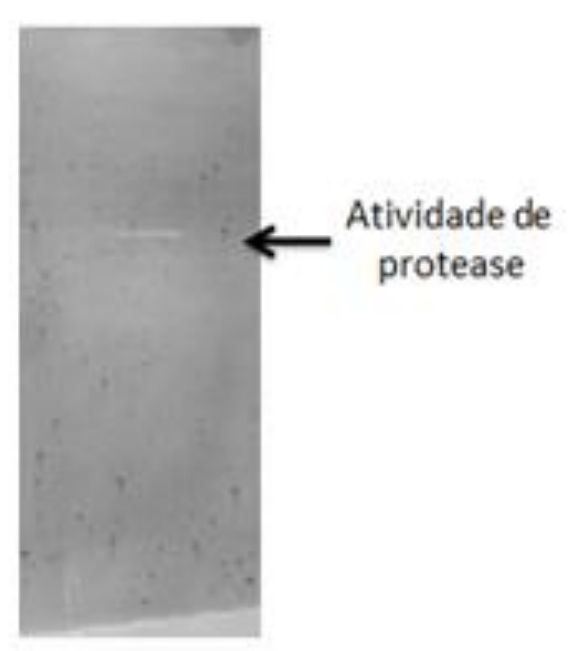

Figura 16. (A) Eletroforese em gel de poliacrilamida. PD - Marcadores de peso molecular (97 - 14,4 $\mathrm{kDa}, \mathrm{GE}$ Lifesciences). EB - Extrato bruto do fungo endofítico BR. DEAE - Amostra semi--purificada em coluna de troca aniônica DEAE FF. (B) Zimograma em gel de poliacrilamida contendo $0,2 \%$ de gelatina como substrato. 
Dadshahi e colaboradores (12) purificaram uma protease produzida por Penaeus vannamei utilizando cromatografia de troca aniônica em coluna DEAEcelulose combinada com outros processos de purificação. A protease isolada tinha peso molecular de $24 \mathrm{kDa}$. Drapeau (141), também utilizou cromatografia de troca aniônica em coluna DEAE para purificar protease de Staphylococcus Aureus, a mesma coluna foi utilizada por Nam e colaboradores (142) para purificar protease cisteínica obtida da fruta Pyrus pyrifolia com tamanhos de 36 e 38 kDa.

Rojas (143) purificou uma protease produzida por fungo filamentoso isolado de papel deteriorado com tamanho de $35 \mathrm{kDa}$ utilizando coluna de troca aniônica DEAE de fluxo rápido (DEAE-FF).

$O$ peso molecular da protease semipurificada neste trabalho difere-se ainda das relatadas para protease produzida por A. foetidus com peso molecular de 50,6 kDa estudada por Souza e colaboradores (117), produzida por Mucor subtilissimus UCP 1262 (97 kDa) purificada por nascimento e colaboradores (2016) (144), Cellulomonas bogoriensis (18,3 kDa) purificada por Li e colaboradores (2016) (126), Ficus caricas (41 kDa) purificada por Rasovic e colaboradores (2014) (123), A. flavus MTCC 9952 (38 kDa) purificada por Yadav (2015) e ainda, da serino-protease produzida por Sardinella aurita (14,2 kDa) purificada por Hayet (2011) (145) e da protease queratinolítica produzida por Aspergullus parasiticus (36 kDa) purificada por Anitha e Palanivelu (2013) (121). No entanto, o valor de 55,27 kDa está dentro do faixa de peso molecular já descrita na literatura.

\subsection{CARACTERIZAÇÃO DA ENZIMA SEMIPURIFICADA}

\subsubsection{Avaliação do $\mathrm{pH}$ na atividade proteolítica}

$\mathrm{O}$ pH ótimo da enzima semipurificada foi identificado como sendo 7,0 (Figura 17), este resultado esta em acordo com a literatura onde vários estudos com fungos filamentosos e outros microrganismos relatam este $\mathrm{pH}$ ótimo para atividade da enzima protease com aplicação em industrias como a cosmética, de detergente e alimentícia. Dadshahi e colaboradores (12) purificaram protease excretada por Penaeus vannamei com pH ótimo 7,0, Hernandéz-Martinez (146) purificou e 
caracterizou serina protease produzida por Aspergillus fumigatus com atividade enzimática máxima em pH 7,0, Anitha e Palanivelu (121) caracterizaram uma protease queratinolítica produzida por de A. parasíticus com pH ótimo 7,0.

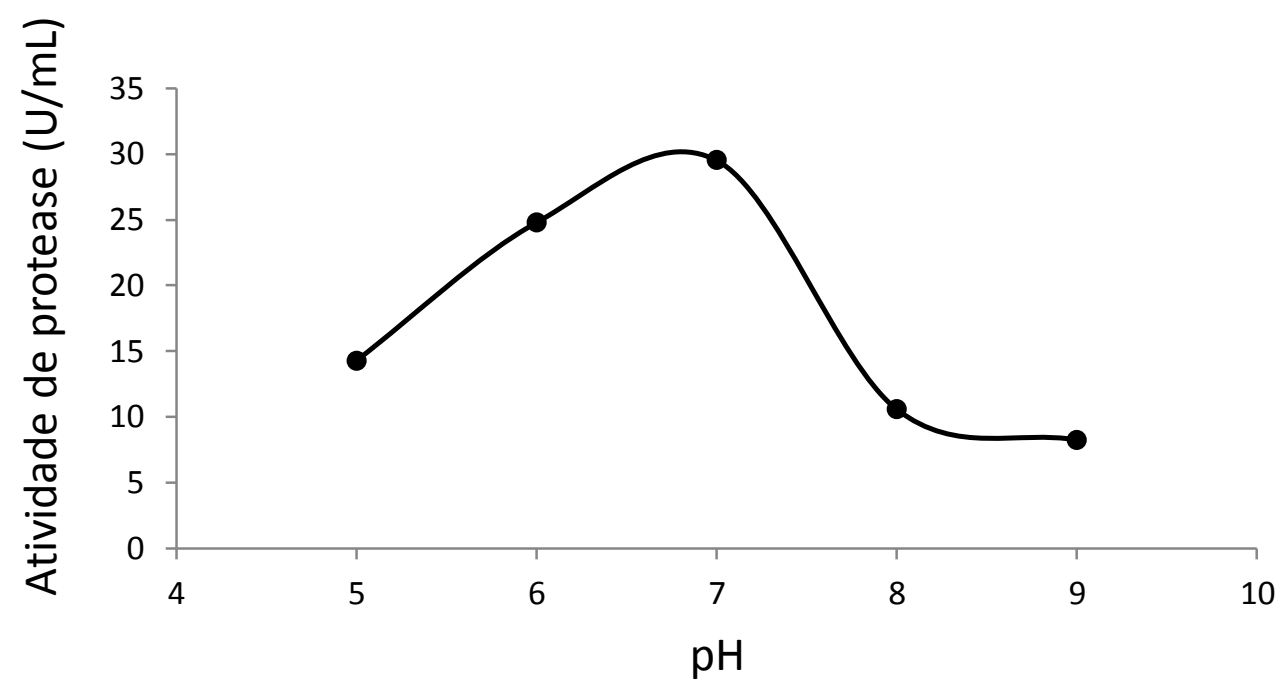

Figura 17. Avaliação do $\mathrm{pH}$ ótimo para a enzima semipurificada. $E$ ensaio foi realizado nos valores de pH 5,0 a 9,0, e o pH ótimo foi 7,0, quando avaliada a atividade proteolítica da amostra.

\subsubsection{Avaliação da temperatura na atividade proteolítica}

A avaliação da temperatura ótima para atividade da protease estudada foi realizada nas temperaturas $40,50,60,70$ e $80^{\circ} \mathrm{C}$ (Figura 18), o ensaio foi realizado conforme o item 4.8. A melhor temperatura de atividade enzimática foi $60^{\circ} \mathrm{C}$, assim como, para o ensaio realizado com o extrato bruto. A enzima também teve atividade alta em $50^{\circ} \mathrm{C}$, temperatura geralmente utilizada em lavanderias, tornando-se interessante para esta aplicação industrial. O resultado obtido está em acordo com a literatura onde $\mathrm{Li}$ e colaboradores (125), que caracterizaram uma protease extracelular produzida por Clonostachys rósea com melhor atividade enzimática em $60^{\circ} \mathrm{C}$. Hernandéz-Martinez e colaboradores (146) purificaram e caracterizaram serina protease produzida por A.fumigatus com atividade enzimática máxima em $60^{\circ} \mathrm{C}$, Li e colaboradores (126) estudaram protease produzida por Cellumonas bogoriensis com temperatura ótima de $60^{\circ} \mathrm{C}$. Rasovic e colaboradores (123) caracterizaram protease produzida por Ficus carica com temperatura ótima $60^{\circ} \mathrm{C}$, 
Hayet e colaboradores (122) caracterizaram serina protease excretada por Sardinella aurita com melhor atividade proteolítica em $60^{\circ} \mathrm{C}$.

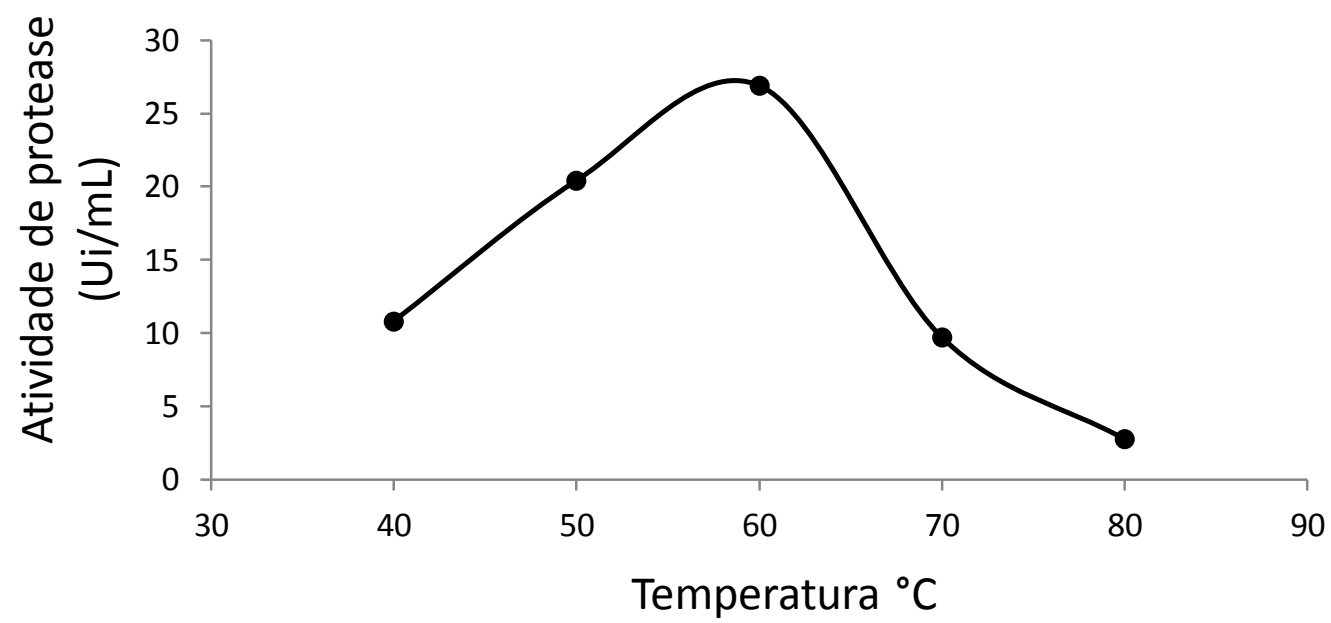

Figura 18. Avaliação da melhor temperatura para atividade enzimática de protease. $O$ ensaio foi realizado em temperaturas de $40^{\circ} \mathrm{C}$ a $80^{\circ} \mathrm{C}$ e a temperatura otima foi de $60^{\circ} \mathrm{C}$

\subsubsection{Avaliação da estabilidade térmica}

A estabilidade térmica da enzima foi realizada a $60^{\circ} \mathrm{C}$ durante 150 minutos (Figura 19). A enzima foi $100 \%$ estável durante 60 minutos, após este tempo a atividade enzimática inicial $(21,90 \mathrm{UI} / \mathrm{mL})$ caiu para 7,61 UI/mL após 120 minutos de incubação.

Meheb e colaboradores (147) estudaram uma protease produzida por Thermoascus aurantiacusa que manteve $100 \%$ de estabilidade a $60^{\circ} \mathrm{C}$ durante 1 hora. Uma protease alcalina produzida por $A$. niger, estudada por Devi e colaboradores (62) foi avaliada quanto a sua estabilidade térmica e foi estável durante 60 minutos a $40^{\circ} \mathrm{C}$ e após este tempo foi perdendo atividade. 


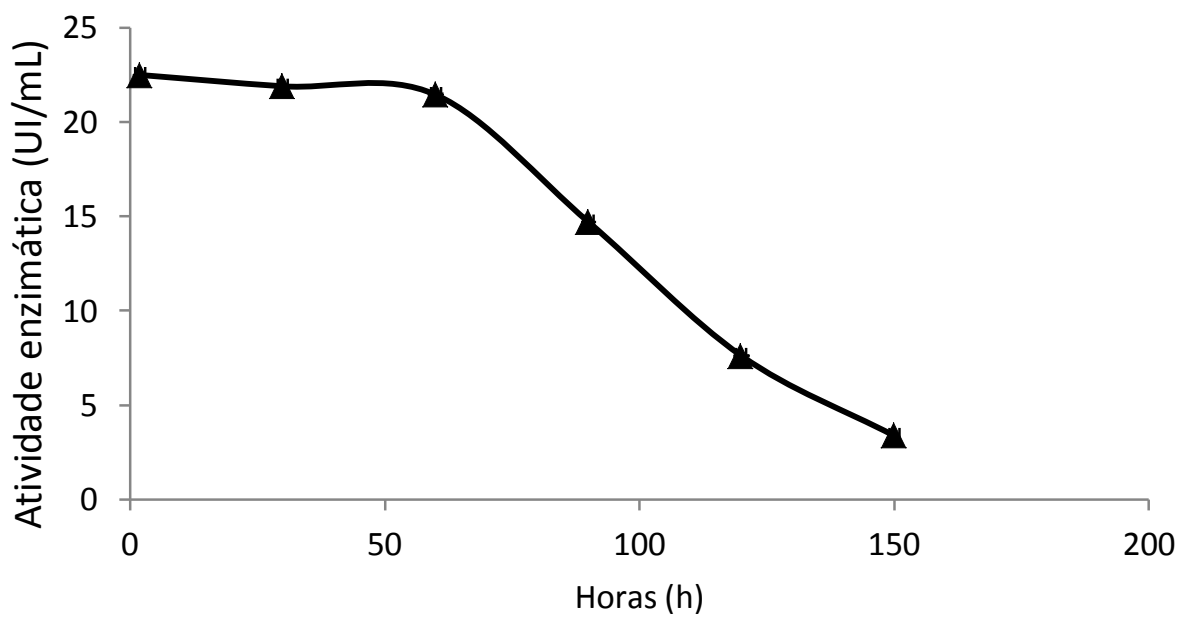

Figura 19. Estabilidade térmica da enzima realizada a $50^{\circ} \mathrm{C}$ e pH 7,0.

O resultado obtido neste experimento é relevante para a aplicação desta protease na Indústria de detergente, pois a enzima é estável em alta temperatura por 1 hora. Algumas máquinas de lavar possuem a opção de aquecer a água para facilitar a retirada de sujidades das roupas a uma temperatura de $50^{\circ} \mathrm{C}$ a $60^{\circ} \mathrm{C}$, esta enzima, portanto não perderia atividade pelo aquecimento da água, tornando-a uma boa opção para esta indústria.

\subsection{TRIAGEM PARA APLICAÇÃO ENZIMÁTICA DA PROTEASE}

Os ensaios de aplicação foram realizados tanto com o extrato bruto liofilizado, com atividade específica de $0,37 \mathrm{Ul} / \mathrm{mg}$ de proteína, quanto com a amostra semipurificada com atividade especifica de $1,36 \mathrm{Ul} / \mathrm{mg}$ de proteína.

A protease estudada não mostrou atividade significativa para os ensaios de atividade queratinolítica, atividade colagenolítica e atividade anticoagulante no leite. As proteases são um grupo muito extenso e heterogêneo de enzimas. Embora estas basicamente clivem ligações peptídicas, existem diferenças individuais entre elas (15). Para ter atividade na coagulação do leite, a protease deve ter afinidade pela caseína, enquanto para ter atividade colagenolítica a enzima deve ter maior afinidade pelo substrato colágeno. Em relação a atividade queratinolítica a enzima 
deve ter afinidade pelo substrato queratina, estes são apenas três exemplos, entre a ampla gama de substratos pelos quais as proteases podem ter maior afinidade.

$\mathrm{Na}$ indústria de detergente para roupas, a amostra estudada foi capaz de melhorar a retirada de manchas em tecido quando adicionada ao detergente (Figura 20), é possível ver que todas as manchas (molho de tomate, suco de couve, sangue de carne bovina e café) foram mais eficientemente retiradas quando lavadas em solução contendo detergente juntamente com solução de enzima.

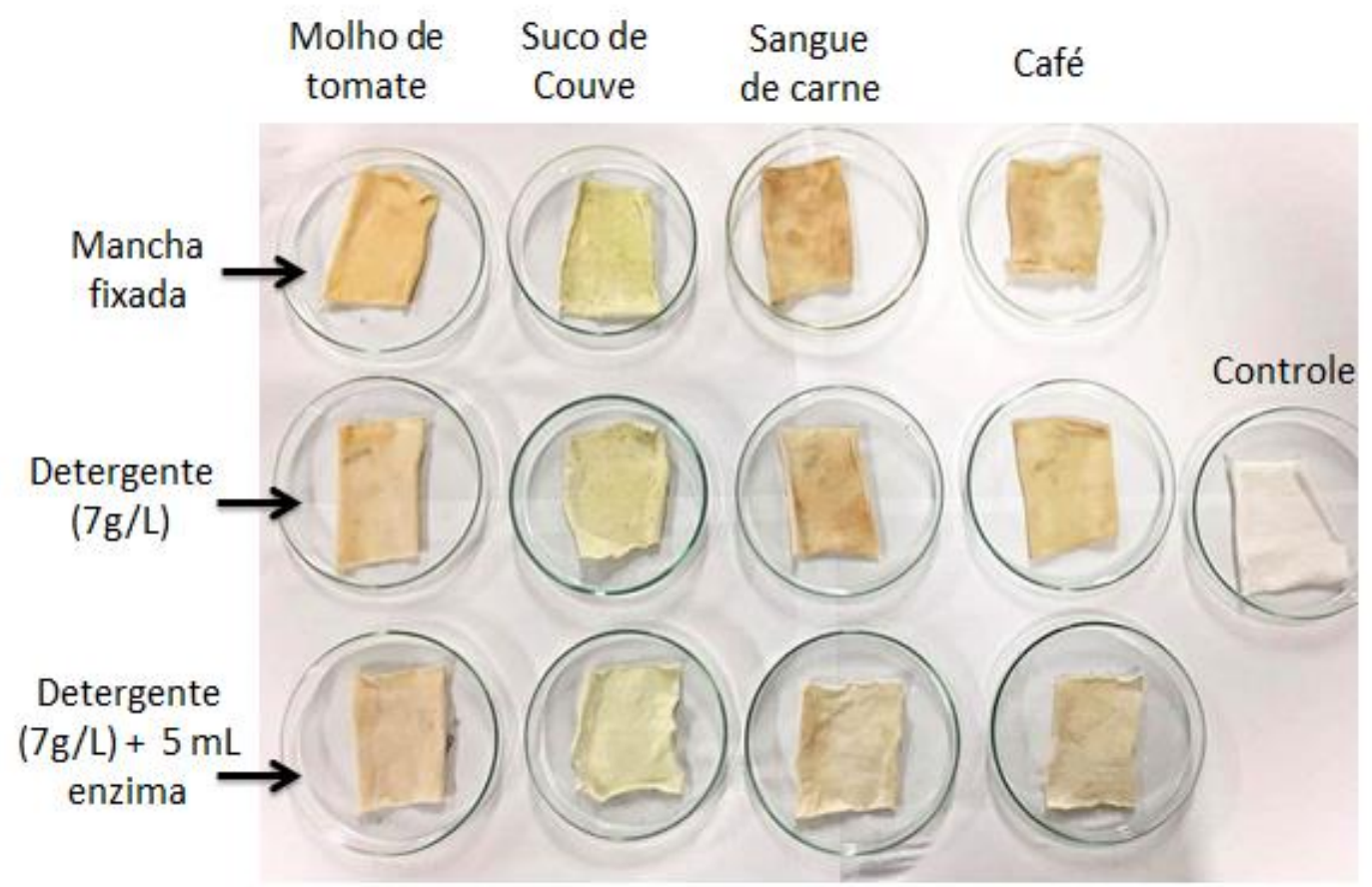

Figura 20. Tecidos de algodão manchados com molho de tomate, suco de couve, sangue de carne bovina e café. As machas foram fixadas com clorofórmio $2 \%$ e lavadas em agua corrente antes do ensaio. A segunda fileira mostra os tecidos lavados a $50^{\circ} \mathrm{C}$, em shaker com rotação de $150 \mathrm{rpm}$ contendo $25 \mathrm{~mL}$ de detergente em concentração de $7 \mathrm{~g} / \mathrm{L}$. A terceira fileira mostra os tecidos lavados com $20 \mathrm{~mL}$ de solução de detergente $+5 \mathrm{~mL}$ de solução enzimática.

A mancha retirada com mais nitidez foi a de sangue de carne bovina, portanto, o ensaio para retirada de manchas foi realizado novamente, desta vez com a enzima semipurificada, apenas para esta mancha. A amostra foi eficaz em conjunto com o detergente, realizando uma melhor remoção da mancha, como pode ser visto na

Figura 21. 


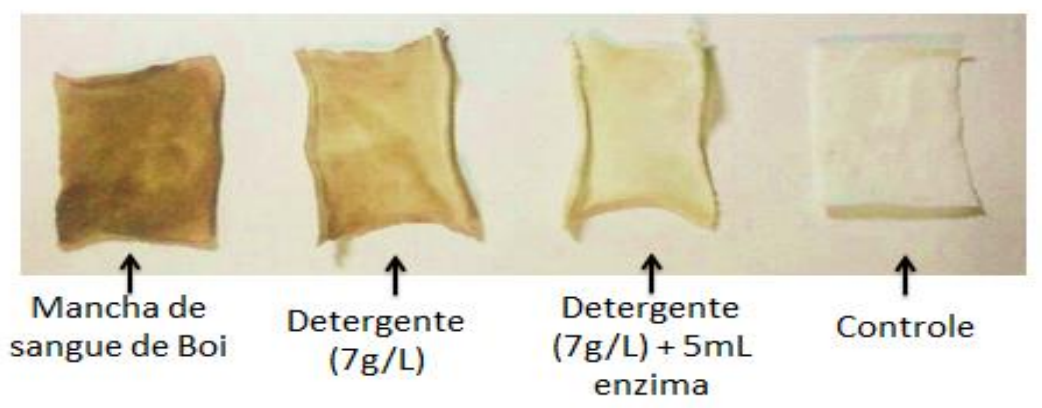

Figura 21. Tecidos de algodão manchados com sangue de carne bovina. As machas foram fixadas com clorofórmio $2 \%$ e lavadas em agua corrente antes do ensaio. O segundo tecido foi lavado a $50^{\circ} \mathrm{C}$, em shaker com rotação de $150 \mathrm{rpm}$ contendo $25 \mathrm{~mL}$ de detergente em concentração de $7 \mathrm{~g} / \mathrm{L}$. O terceiro tecido foi lavado com $20 \mathrm{~mL}$ de solução de detergente $+5 \mathrm{~mL}$ de solução enzimática somipurificada.

Os resultados obtidos neste experimento estão em acordo com a literatura, Vijayalakshmi e colaboradores (60) também obtiveram bons resultados na retirada de manchas de beterraba, cenoura, suco de folhas verdes, café e chá utilizando uma protease produzida por Bacillus RV.B2.90. A melhor atividade como removedor de manchas ocorreu no tecido sujo com sangue de boi, esse resultado esta em acordo com a literatura, onde Rai e Mukerjee (59) testaram protease produzida por bacillus subitilis DM-04 para retirar macha de sangue e obtiveram resultado positivo quando comparado com a utilização apenas de detergente. Anwar e Saleemuddin (148) estudaram a aplicação de suco digestivo do inseto Spilosoma obliqua contendo lipases, proteases e amilases para aplicação como removedor de mancha de sangue em tecido, o resultado foi positivo, a amostra foi capaz de remover a mancha sozinha ou em adição a detergentes.

\subsubsection{Compatibilidade com detergentes}

Um dos requisitos essenciais para a utilização de proteases na formulação de um detergente é a compatibilidade com este. Por isso foi testada a compatibilidade da enzima semipurificada com três marcas comerciais de detergentes para lavar roupas. A protease produzida pelo fungo BR demonstrou ser estável e compatível com dois dos detergentes testados. No detergente M1, após 1 hora a atividade enzimática residual foi de $81 \%$ e no detergente $\mathrm{M} 3$ foi de $78 \%$. O detergente $\mathrm{M} 2$ foi o 
que causou maior inibição na atividade da protease, onde com 1 hora de encubação, já havia perdido $71 \%$ de sua atividade (Figura 22).

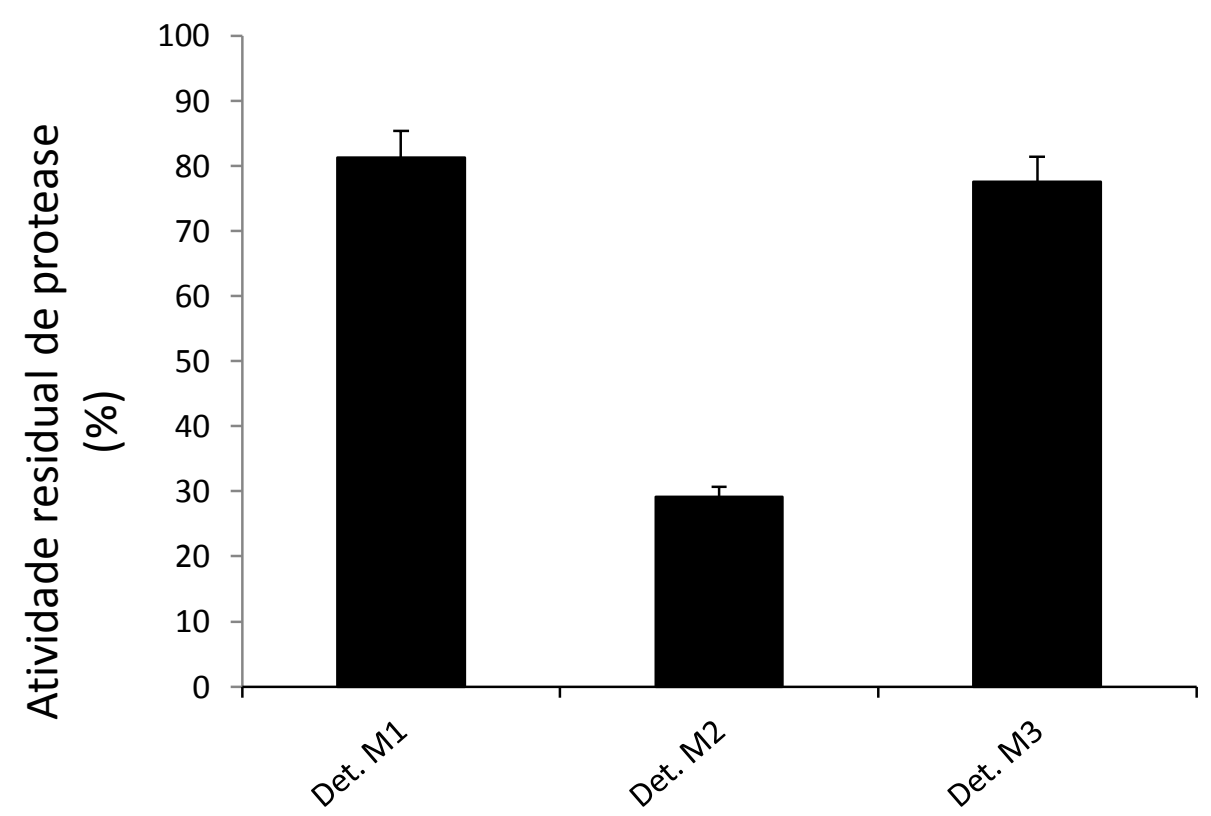

Figura 22. Compatibilidade da protease produzida pelo fungo BR com detergentes de marcas comerciais (M1, M2 e M3) a $50^{\circ} \mathrm{C}$ por 1 hora. As barras de erro representam 95\% dos limites de confiança para os resultados obtidos.

Os resultados obtidos corroboram com a literatura onde Banik e Prakash (64) estudaram uma protease produzida por Bacillus cereus que manteve $80 \%$ de sua estabilidade após 1 hora de incubação com detergentes comerciais. Devi e colaboradores (62) testaram a compatibilidade com detergentes de uma protease alcalina produzida por $A$. niger. Na maioria dos detergentes estudados por esse autor a enzima reteve 80 a 92\% da atividade inicial após uma hora, e em apenas um detergente a atividade caiu para $23 \%$ da inicial após uma hora de incubação.

Phadatare e colaboradores (61) testaram protease alcalina produzida por Conidiobolus coronatus (NCL 86.8.20) para compatibilidade com vários detergentes comerciais e foram obtidos resultados variados. Foram relatadas atividades residuais (após 1 hora a $40^{\circ} \mathrm{C}$ ) de $80 \%, 90 \%, 60 \%$ e 56\% a depender do detergente testado. Vijayalakshmi e colaboradores (60) estudou protease de Bacillus RV.B2.90 que 
demonstrou excelente estabilidade em diversos detergentes, com atividades residuais de $99,98,97,90$ e $77 \%$ a $65^{\circ} \mathrm{C}$ por 3 horas. 


\section{CONCLUSÃO}

$>$ Foram isolados 58 fungos endofíticos.

> Trinta e seis dos 58 fungos isolados foram capazes de produzir proteases.

$>$ O fungo endofítico com maior produção enzimática neste trabalho foi o de código "BR" com atividade de aproximadamente $41 \mathrm{UI}$.

$>\mathrm{O}$ fungo BR possui para protease valores ótimos de atividade em $\mathrm{pH}$ 7,0 e temperatura de $60^{\circ} \mathrm{C}$.

$>$ O meio estudado neste trabalho com melhores resultados para produção de protease continha meio mínimo, peptona $2 \%$, extrato de levedura $1 \%$ e glicose 2\% (MMPLG).

$>$ O tempo de fermentação escolhido para realizar a purificação de protease pelo fungo endofítico foi 192 horas.

$>$ A protease produzida foi parcialmente purificada utilizando coluna de troca iônica DEAE FF.

$>$ A protease parcialmente purificada apresentou maior atividade em $\mathrm{pH} 7,0$ e temperatura de $60^{\circ} \mathrm{C}$ e manteve $100 \%$ de sua atividade durante 60 minutos a $60^{\circ} \mathrm{C}$.

> A protease estudada se mostrou eficiente como removedor de manchas e mostrou compatibilidade com 2 detergentes comerciais testados.

\section{PERSPECTIVAS}

- Identificar o fungo endofítico BR.

> Purificar completamente a enzima protease produzida pelo fungo.

$>$ Continuidade de testes de aplicabilidade.

> Explorar o fungo endofítico BR como possível candidato a manipulação genética visando aumentar o rendimento enzimático. 


\section{REFERENCIAS BIBLIOGRAFICAS}

1. Lima TLS, Jesus BM, Souza RRR, Okamoto KA, Lima R, Fraceto FL. Estudo da atividade proteolítca de Enzimas Presentes em frutos. Quím Nova Esc. 2008 28: p. 47-9.

2. Secchi G. Role of protein in cosmetics. Clinics in dermatology. 2008;26(4):321-5.

3. Zimmer KR, Borré GL, Trentin D, Júnior CW, Frasson AP, Graeff A, et al. Enzimas microbianas de uso terapêutico e diagnóstico clínico. Rev Liberato, Novo Hamburgo. 2009;10(14):123-37.

4. Sumantha A, Larroche C, Pandey A. Microbiology and industrial biotechnology of food-grade proteases: a perspective. Food Technol Biotech. 2006;44(2):211.

5. Zanphorlin L, Cabral H, Arantes E, Assis D, Juliano L, Juliano M, et al. Purification and characterization of a new alkaline serine protease from the thermophilic fungus Myceliophthora sp. Process biochem. 2011;46(11):2137-43.

6. Zambare V, Nilegaonkar S, Kanekar P. A novel extracellular protease from Pseudomonas aeruginosa MCM B-327: enzyme production and its partial characterization. N Biotechnol. 2011 2/28/;28(2):173-81.

7. Rao MB, Tanksale AM, Ghatge MS, Deshpande VV. Molecular and biotechnological aspects of microbial proteases. Microbiol Mol Biol Rev. 1998;62(3):597-635.

8. Arima $\mathrm{K}, \mathrm{Yu}$ J, Iwasaki S. [30] Milk-clotting enzyme from Mucor pusillus var. Lindt. METHOD ENZYMOL. 1970;19:446-59.

9. Boyce $A$, Walsh $G$. Identification of fungal proteases potentially suitable for environmentally friendly cleaning-in-place in the dairy industry. Chemosphere. 2012 6//;88(2):211-8.

10. Chiang $\mathrm{BH}, \mathrm{Yu} \mathrm{ZR}$. Fouling and flux restoration of ultrafiltration of passion fruit juice. J Food Sci. 1987;52(2):369-71.

11. Abidi F, Limam F, Nejib MM. Production of alkaline proteases by Botrytis cinerea using economic raw materials: assay as biodetergent. Process Biochem. 2008;43(11):1202-8. 
12. Dadshahi Z, Homaei A, Zeinali F, Sajedi RH, Khajeh K. Extraction and purification of a highly thermostable alkaline caseinolytic protease from wastes Penaeus vannamei suitable for food and detergent industries. Food Chem. 2016;202:110-5.

13. Dayanandan A, Kanagaraj J, Sounderraj L, Govindaraju R, Rajkumar GS. Application of an alkaline protease in leather processing: an ecofriendly approach. $J$ of Cleaner Prod. 2003;11(5):533-6.

14. Del Rosso JQ. Application of Protease Technology in Dermatology: Rationale for Incorporation into Skin Care with Initial Observations on Formulations Designed for Skin Cleansing, Maintenance of Hydration, and Restoration of the Epidermal Permeability Barrier. J Clin Aesthet Dermatol 2013;6(6):14.

15. Vermelho AB, Melo A, Sá M, Santos A, d'Avila-Levy CM, Couri S, et al. Enzimas proteolíticas: Aplicações biotecnológicas. Enzimas em biotecnologiaProdução, aplicações e mercado. 2008:273-87.

16. Strobel G, Daisy B, Castillo U, Harper J. Natural products from endophytic microorganisms. J Nat Prod. 2004;67(2):257-68.

17. Borges WdS, Borges KB, Bonato PS, Said S, Pupo MT. Endophytic fungi: natural products, enzymes and biotransformation reactions. Curr Org Chem. 2009;13(12):1137-63.

18. Schulz B, Boyle C, Draeger S, Römmert A-K, Krohn K. Endophytic fungi: a source of novel biologically active secondary metabolites. Mycol Res. 2002;106(09):996-1004.

19. Lario LD, Chaud L, Almeida M, Converti A, Sette LD, Pessoa A, Jr. Production, purification, and characterization of an extracellular acid protease from the marine Antarctic yeast Rhodotorula mucilaginosa L7. Fungal Biol. 2015 Nov;119(11):1129-36.

20. Sabotič J, Kos J. Microbial and fungal protease inhibitors-current and potential applications. Appl Microbiol Biotechnol 2012;93(4):1351-75.

21. Rawlings ND, Morton FR, Barrett AJ. MEROPS: the peptidase database. Nucleic acids res 2006;34(suppl 1):D270-D2.

22. Rawlings ND, Morton FR, Barrett AJ. MEROPS: the peptidase database. Nucleic acids research. 2006;34(suppl 1):D270-D2.

23. Schaller A. A cut above the rest: the regulatory function of plant proteases. Planta. 2004;220(2):183-97. 
24. Saran S, Isar J, Saxena RK. A modified method for the detection of microbial proteases on agar plates using tannic acid. $J$ Biochem Biophys Methods. 2007;70(4):697-9.

25. Khan F. New microbial proteases in leather and detergent industries. Innov Res Chem. 2013;1(1):1-6.

26. Dadshahi Z, Homaei A, Zeinali F, Sajedi RH, Khajeh K. Extraction and purification of a highly thermostable alkaline caseinolytic protease from wastes Litopenaeus vannamei suitable for food and detergent industries. Food Chem. 2016 7/1/;202:110-5.

27. Murthy PS, Kusumoto K-I. Acid protease production by Aspergillus oryzae on potato pulp powder with emphasis on glycine releasing activity: $A$ benefit to the food industry. Food Bioprod Process 2015;96:180-8.

28. Schaechter M. Encyclopedia of microbiology: Academic Press; 2009.

29. Anitha TS, Palanivelu P. Purification and characterization of an extracellular keratinolytic protease from a new isolate of Aspergillus parasiticus. Protein Expr Purif 2013;88:214-20. PubMed PMID: 23337085. eng.

30. Smith W, Bishop M, Gillis G, Maibach H. Topical proteolytic enzymes affect epidermal and dermal properties. Int J Cosmet Sci. 2007;29(1):15-21.

31. Gupta R, Beg Q, Khan S, Chauhan B. An overview on fermentation, downstream processing and properties of microbial alkaline proteases. Appl microbiol biotechnol. 2002;60(4):381-95.

32. Gohel SD, Singh SP. Purification strategies, characteristics and thermodynamic analysis of a highly thermostable alkaline protease from a salttolerant alkaliphilic actinomycete, Nocardiopsis alba OK-5. J chromatogr B. 2012;889:61-8.

33. Vieille C, Zeikus GJ. Hyperthermophilic enzymes: sources, uses, and molecular mechanisms for thermostability. Microbiol Mol Biol Rev. 2001;65(1):1-43.

34. DO EGITO AS, LAGUNA LE. PRODUTOS REGIONAIS DERIVADOS DE LEITE DE CABRAS E PERSPECTIVAS DE MERCADO PARA O BRASIL. Anais de Simpósios da 43aㅡ Reunião Anual da SBZ; João Pessoa - PB2006.

35. Eide MH, Homleid JP, Mattsson B. Life cycle assessment (LCA) of cleaningin-place processes in dairies. LWT-FOOD SCI TECHNOL 2003 5//;36(3):303-14. 
36. Paul T, Jana A, Das A, Mandal A, Halder SK, Das Mohapatra PK, et al. Smart cleaning-in-place process through crude keratinase: an eco-friendly cleaning techniques towards dairy industries. J CLEAN PROD. 2014 8/1/;76:140-53.

37. Green ML. Review of the progress of dairy science: milk coagulants. J Dairy Res 1977;44(1):159-88.

38. Raposo S, Domingos A. Purification and characterization milk-clotting aspartic proteinases from Centaurea calcitrapa cell suspension cultures. Process Biochem 2008;43(2):139-44.

39. Mazorra-Manzano MA, Moreno-Hernández JM, Ramírez-Suarez JC, TorresLlanez MdJ, González-Córdova AF, Vallejo-Córdoba B. Sour orange Citrus aurantium L. flowers: A new vegetable source of milk-clotting proteases. Food sci technol. 2013 12//;54(2):325-30.

40. Corrons MA, Bertucci JI, Liggieri CS, López LMI, Bruno MA. Milk clotting activity and production of bioactive peptides from whey using Maclura pomifera proteases. Food sci technol. 2012 6//;47(1):103-9.

41. Monteiro VN, SILVA R. Aplicações industriais da biotecnologia enzimática. R Proc Quím. 2009;3(5):9-23.

42. Hamada S, Suzuki K, Aoki N, Suzuki Y. Improvements in the qualities of gluten-free bread after using a protease obtained from Aspergillus oryzae. J Cereal Sci 2013 1//;57(1):91-7.

43. Hatta E, Matsumoto K, Honda Y. Bacillolysin, papain, and subtilisin improve the quality of gluten-free rice bread. J Cereal Sci. 2015 1//;61:41-7.

44. Naveena BM, Mendiratta SK, Anjaneyulu ASR. Tenderization of buffalo meat using plant proteases from Cucumis trigonus Roxb (Kachri) and Zingiber officinale roscoe (Ginger rhizome). Meat Sci. 2004 11//;68(3):363-9.

45. Rawdkuen S, Jaimakreu M, Benjakul S. Physicochemical properties and tenderness of meat samples using proteolytic extract from Calotropis procera latex. Food Chem. 2013 1/15/;136(2):909-16.

46. Sandri IG, Fontana RC, Barfknecht DM, da Silveira MM. Clarification of fruit juices by fungal pectinases. food sci technol 2011;44(10):2217-22.

47. Cerreti M, Liburdi K, Benucci I, Esti M. The effect of pectinase and protease treatment on turbidity and on haze active molecules in pomegranate juice. food sci technol. 2016 11//;73:326-33. 
48. Mosafa L, Moghadam M, Shahedi M. Papain enzyme supported on magnetic nanoparticles: Preparation, characterization and application in the fruit juice clarification. Chinese J Cat 2013 10//;34(10):1897-904.

49. Jian S, Wenyi $\mathrm{T}$, Wuyong $\mathrm{C}$. Kinetics of enzymatic unhairing by protease in leather industry. J CLEAN PROD 2011 3//;19(4):325-31.

50. Giongo JL. Caracterização e aplicação de proteases produzidas por linhagens de Bacillus sp: Universidade Federal do Rio Grande do Sul.; 2006.

51. Foroughi F, Keshavarz T, Evans CS. Specificities of proteases for use in leather manufacture. J chem tecnhol biot. 2006;81(3):257-61.

52. Riffel A, Ortolan S, Brandelli A. De-hairing activity of extracellular proteases produced by keratinolytic bacteria. J chem technol biot. 2003;78(8):855-9.

53. Giongo JL, Lucas FS, Casarin F, Heeb P, Brandelli A. Keratinolytic proteases of Bacillus species isolated from the Amazon basin showing remarkable de-hairing activity. World J microb biot. 2007;23(3):375-82.

54. Hameed A, Natt M, Evans C. Production of alkaline protease by a new Bacillus subtilis isolate for use as a bating enzyme in leather treatment. World $\mathrm{J}$ microb biot. 1996;12(3):289-91.

55. Gupta R, Gigras P, Mohapatra H, Goswami VK, Chauhan B. Microbial aamylases: a biotechnological perspective. Process Biochem. 2003 6/30/;38(11):1599-616.

56. Vojcic L, Pitzler C, Körfer G, Jakob F, Martinez R, Maurer K-H, et al. Advances in protease engineering for laundry detergents. N Biotechnol. 2015;32(6):629-34.

57. Rodríguez VB, Alameda EJ, Gallegos JFM, Requena AR, López AIG. Thermal deactivation of a commercial a-amylase from Bacillus licheniformis used in detergents. BIOCHEM ENG J. 2006 1//;27(3):299-304.

58. Vojcic L, Pitzler C, Körfer G, Jakob F, Ronny M, Maurer K-H, et al. Advances in protease engineering for laundry detergents. New Biotechnol. 2015 12/25/;32(6):629-34.

59. Rai SK, Mukherjee AK. Statistical optimization of production, purification and industrial application of a laundry detergent and organic solvent-stable subtilisin-like serine protease (Alzwiprase) from Bacillus subtilis DM-04. Biochem Eng J. 2010 $1 / 15 / ; 48(2): 173-80$. 
60. Vijayalakshmi S, Venkatkumar S, Thankamani V. Screening of alkalophilic thermophilic protease isolated from Bacillus RV. B2. 90 for Industrial applications. Res Biotechnol. 2011;2(3).

61. Phadatare SU, Deshpande VV, Srinivasan MC. High activity alkaline protease from Conidiobolus coronatus (NCL 86.8.20): Enzyme production and compatibility with commercial detergents. Enzyme Microb Tech. 1993 1993/01/01;15(1):72-6.

62. Devi MK, Banu AR, Gnanaprabha G, Pradeep B, Palaniswamy M. Purification, characterization of alkaline protease enzyme from native isolate Aspergillus niger and its compatibility with commercial detergents. Indian J sci tech 2008;1(7):1-6.

63. Sindhu R, Suprabha G, Shashidhar S. Optimization of process parameters for the production of alkaline protease from Penicillium godlewskii SBSS 25 and its application in detergent industry. Afr J Microbiol Res. 2009;3(9):515-22.

64. Banik RM, Prakash M. Laundry detergent compatibility of the alkaline protease from Bacillus cereus. Microbiological research. 2004;159(2):135-40.

65. Sim Y-C, Lee S-G, Lee D-C, Kang B-Y, Park K-M, Lee J-Y, et al. Stabilization of papain and lysozyme for application to cosmetic products. Biotechnol Lett. 2000;22(2):137-40.

66. Raskovic B, Bozovic O, Prodanovic R, Niketic V, Polovic N. Identification, purification and characterization of a novel collagenolytic serine protease from fig (Ficus carica var. Brown Turkey) latex. Journal of bioscience and bioengineering. 2014 12//;118(6):622-7.

67. Tallis A, Motley TA, Wunderlich RP, Dickerson Jr JE, Waycaster C, Slade HB. Clinical and Economic Assessment of Diabetic Foot Ulcer Debridement with Collagenase: Results of a Randomized Controlled Study. Clin Ther 2013;35(11):1805-20.

68. Roslan NZI, Aziz AA, Sarmidi MR, Aziz RA, editors. Anti-oxidant coated liposome as the delivery system for papain based natural cosmetics. Enabling Science and Nanotechnology (ESciNano), 2010 International Conference on; 2010: IEEE.

69. Cavello IA, Hours RA, Rojas NL, Cavalitto SF. Purification and characterization of a keratinolytic serine protease from Purpureocillium lilacinum LPS \# 876. Process biochem. 2013;48(5-6):972-8. 
70. Villa ALV, Aragão MRS, dos Santos EP, Mazotto AM, Zingali RB, de Souza EP, et al. Feather keratin hydrolysates obtained from microbial keratinases: effect on hair fiber. BMC Biotechnol. 2013;13(1):1.

71. Sanghvi G, Patel H, Vaishnav D, Oza T, Dave G, Kunjadia P, et al. A novel alkaline keratinase from Bacillus subtilis DP1 with potential utility in cosmetic formulation. International journal of biological macromolecules. 2016 6//;87:256-62.

72. Masunaga T. Enzymes in cleansers. In: Rawlings AV, Leyden J, editors. Skin Moisturization2002. p. 385-404.

73. Lods L, Dres C, Johnson C, Scholz D, Brooks G. The future of enzymes in cosmetics. Int J Cosmet Sci. 2000;22(2):85-94.

74. DeHaven C. MECHANISMS OF EXFOLIATION. 2015.

75. Rawlings AV, Voegeli R. Stratum corneum proteases and dry skin conditions. Cell Tissue Res. 2013;351(2):217-35.

76. de Souza FASD, Sales AE, e Silva PEC, Bezerra RP, e Silva GMdM, de Araújo JM, et al. Optimization of production, biochemical characterization and In Vitro evaluation of the therapeutic potential of fibrinolytic enzymes from a new Bacillus Amyloliquefaciens. Macromol Res. 2016:1-9.

77. MM Silva G, Bezerra RP, Teixeira JA, Porto TS, Lima-Filho JL, Porto ALF. Fibrinolytic protease production by new Streptomyces sp: DPUA 1576 from Amazon lichens. Electron J Biotechnol. 2015;18(1):16-9.

78. Agrawal D, Patidar P, Banerjee T, Patil S. Alkaline protease production by a soil isolate of Beauveria felina under SSF condition: parameter optimization and application to soy protein hydrolysis. Process Biochem. 2005 3//;40(3-4):1131-6.

79. Yadav SK, Bisht D, Tiwari S, Darmwal Nandan S. Purification, biochemical characterization and performance evaluation of an alkaline serine protease from Aspergillus flavus MTCC 9952 mutant. Biocatal Agric Biotechnol. 2015;4(4):667-77.

80. Souza PM, Aliakbarian B, Filho EXF, Magalhães PO, Junior AP, Converti A, et al. Kinetic and thermodynamic studies of a novel acid protease from Aspergillus foetidus. Int J Biol Macromol. 2015;81:17-21.

81. Maki CS. Diversidade e potencial biotecnológico de fungos endofíticos de cacau (Theobroma cacao L.): Escola Superior de Agricultura “Luiz de Queiroz; 2006. 82. Faeth $\mathrm{SH}$, Fagan WF. Fungal endophytes: common host plant symbionts but uncommon mutualists. Integr Comp Biol. 2002;42(2):360-8.

83. Bacon CW, White J. Microbial endophytes: CRC Press; 2000. 
84. Carroll G. Fungal endophytes in stems and leaves: from latent pathogen to mutualistic symbiont. Ecology. 1988:2-9.

85. Rodriguez R, White Jr J, Arnold A, Redman R. Fungal endophytes: diversity and functional roles. New Phytol. 2009;182(2):314-30.

86. Azevedo JL, Melo I, Azevedo J. Microrganismos endofíticos. Ecologia microbiana Jaguariúna: EMBRAPA. 1998:117-37.

87. Moricca S, Ragazzi A. Fungal endophytes in Mediterranean oak forests: a lesson from Discula quercina. Phytopathol 2008;98(4):380-6.

88. Hassan AA, Abdessamad D, Peter P. Fungal endophytes: unique plant inhabitants with great promises. Applied microbiology and biotechnology. 2011;90(6):1829-45.

89. Breen J. Acremonium endophyte interactions with enhanced plant resistance to insects. Annu Rev Entomol. 1994;39(1):401-23.

90. Funk $\mathrm{C}$, White $\mathrm{RH}$, Breen J. Importance of Acremonium endophytes in turfgrass breeding and management. Agric Ecosyst Environ. 1993;44(1):215-32.

91. Stierle A, Strobel G, Stierle D. Taxol and taxane production by Taxomyces andreanae, an endophytic fungus of Pacific yew. Science 1993;260:214-.

92. Guo B, Wang Y, Zhou X, Hu K, Tan F, Miao Z, et al. An endophytic taxolproducing fungus BT2 isolated from Taxus chinensis var. mairei. African $\mathrm{J}$ Biotech. 2006;5(10).

93. Strobel G, Yang X, Sears J, Kramer R, Sidhu RS, Hess W. Taxol from Pestalotiopsis microspora, an endophytic fungus of Taxus wallachiana. Microbiology (Reading, England). 1996;142(2):435-40.

94. Li J-y, Strobel G, Sidhu R, Hess W, Ford EJ. Endophytic taxol-producing fungi from bald cypress, Taxodium distichum. Microbiology (Reading, England). 1996;142(8):2223-6.

95. Aly $\mathrm{AH}$, Debbab A, Proksch P. Fungal endophytes: unique plant inhabitants with great promises. Applied microbiology and biotechnology. 2011;90(6):1829-45.

96. Tan RX, Zou WX. Endophytes: a rich source of functional metabolites. Nat Prod Rep. 2001;18(4):448-59.

97. Chapla VM, Biasetto CR, Araujo AR. Fungos endofíticos: uma fonte inexplorada e sustentável de novos e bioativos produtos naturais. Rev Virtual Quím. 2012;5(3):421-37. 
98. Lindstrom JT, Belanger FC. Purification and characterization of an endophytic fungal proteinase that is abundantly expressed in the infected host grass. Plan Physiol. 1994;106(1):7-16.

99. Maria G, Sridhar K, Raviraja N. Antimicrobial and enzyme activity of mangrove endophytic fungi of southwest coast of India. Journal Agric technol. 2005;1:67-80.

100. Fuentes-Ramirez LE, Jimenez-Salgado T, Abarca-Ocampo I, CaballeroMellado J. Acetobacter diazotrophicus, an indoleacetic acid producing bacterium isolated from sugarcane cultivars of Mexico. PLANT SOIL. 1993;154(2):145-50.

101. de Oliveira Silva RL, Luz JS, da Silveira EB, Cavalcante UMT. Fungos endofíticos em Annona spp.: isolamento, caracterização enzimática e promoção do crescimento em mudas de pinha (Annona squamosa L.). Acta bot bras. 2006;20(3):649-55.

102. Petrini O, Sieber TN, Toti L, Viret O. Ecology, metabolite production, and substrate utilization in endophytic fungi. Nat toxins. 1993;1(3):185-96.

103. Charney J, Tomarelli RM. A colorimetric method for the determination of the proteolytic activity of duodenal juice. J biol chem. 1947;171:501-5.

104. Bradford MM. A rapid and sensitive method for the quantitation of microgram quantities of protein utilizing the principle of protein-dye binding. Anal Biochem. $1976 ; 72(1-2): 248-54$.

105. Laemmli U. Most commonly used discontinuous buffer system for SDS electrophoresis. Nature. 1970;227:680-5.

106. Blum H, Beier H, Gross HJ. Improved silver staining of plant proteins, RNA and DNA in polyacrylamide gels. Electrophoresis. 1987;8(2):93-9.

107. Bischoff KM, Shi L, Kennelly PJ. The detection of enzyme activity following sodium dodecyl sulfate-polyacrylamide gel electrophoresis. Analytical biochemistry. 1998;260(1):1-17.

108. Sousa M, Souza O, Maciel M, Cruz R, Rêgo M, Magalhães O, et al. Keratinolytic potential of fungi isolated from soil preserved at the Micoteca URM. Eur J Biotechnol Biosci. 2015;3:10-5.

109. Rosso BU, Lima CdA, Porto TS, de Oliveira Nascimento C, Pessoa Junior A, Converti $A$, et al. Partitioning and extraction of collagenase from Penicillium aurantiogriseum in poly(ethylene glycol)/phosphate aqueous two-phase system. Fluid Phase Equilibr. 2012 12/15/;335:20-5. 
110. de Souza Vieira PD, da Silva FG, Silva WMT, Cavalcanti PA, Lima D. Primeiro registro de fungos endofíticos em folhas de Ixora coccinea L. em Pernambuco, Brasil. Revista Brasileira de Biociências. 2012;10(1):1.

111. Cafêu MC, Silva GH, Teles HL, da SBolzani V, Araújo AR, Young MCM, et al. Substâncias antifúngicas de Xylaria sp., um fungo endofítico isolado de Palicourea marcgravii (Rubiaceae). Química Nova. 2005;28(6):991.

112. Huang $Q$, An $H$, Song $H$, Mao $H$, Shen W, Dong J. Diversity and biotransformative potential of endophytic fungi associated with the medicinal plant Kadsura angustifolia. Res Microbiol. 2015 1//;166(1):45-55.

113. Nascimento TL, Oki Y, Lima DMM, Almeida-Cortez JS, Fernandes GW, Souza-Motta CM. Biodiversity of endophytic fungi in different leaf ages of Calotropis procera and their antimicrobial activity. Fungal Ecol. 2015 4//;14:79-86.

114. Jiang S, Qian D-w, Yang N-y, Tao J-h, Duan J-a. Biodiversity and Antimicrobial Activity of Endophytic Fungi in Angelica sinensis. Chin Herb Med. 2013 11//;5(4):264-71.

115. Rodarte MP, Dias DR, Vilela DM, Schwan RF. Proteolytic activities of bacteria, yeasts and filamentous fungi isolated from coffee fruit (Coffea arabica L.). Acta Sci Agron. 2011;33(3):457-64.

116. Orlandelli RC, de Almeida TT, Alberto RN, Polonio JC, Azevedo JL, Pamphile JA. Antifungal and proteolytic activities of endophytic fungi isolated from Piper hispidum Sw. Brazilian journal of microbiology : [publication of the Brazilian Society for Microbiology]. 2015 Jun;46(2):359-66. PubMed PMID: 26273250. Pubmed Central PMCID: PMC4507527. Epub 2015/08/15. eng.

117. de Souza PM. Produção de proteases por fungos filamentosos isolados do cerrado do centro-oeste brasileiro: Universidade de São Paulo; 2015.

118. Novelli PK, Barros MM, Fleuri LF. Novel inexpensive fungi proteases: Production by solid state fermentation and characterization. Food chem. 2016;198:119-24.

119. Nascimento C, dos Santos V, Andrade M. Analise da produção de proteae e lipase por fungos filamentosos isolados do fruto da macaúba (Acrocomia aculeada (jaqc) lood. ex mart). Blucher Chemical Engineering Proceedings. 2014;1(2):336-43. 120. Chaud LCS, Lario LD, Bonugli-Santos RC, Sette LD, Pessoa Junior A, Felipe MdGdA. Improvement in extracellular protease production by the marine antarctic yeast Rhodotorula mucilaginosa L7. New Biotechnol. 2016 12/25/;33(6):807-14. 
121. Anitha TS, Palanivelu P. Purification and characterization of an extracellular keratinolytic protease from a new isolate of Aspergillus parasiticus. Protein Expr Purif. 2013 4//;88(2):214-20.

122. Hayet BK, Rym N, Ali B, Sofiane G, Moncef N. Low molecular weight serine protease from the viscera of sardinelle (Sardinella aurita) with collagenolytic activity: Purification and characterisation. Food Chem. 2011 2/1/;124(3):788-94.

123. Raskovic B, Bozovic O, Prodanovic R, Niketic V, Polovic N. Identification, purification and characterization of a novel collagenolytic serine protease from fig (Ficus carica var. Brown Turkey) latex. Journal of bioscience and bioengineering. 2014 12//;118(6):622-7.

124. Shankar S, Rao M, Laxman RS. Purification and characterization of an alkaline protease by a new strain of Beauveria sp. Process Biochem. 2011 2//;46(2):579-85.

125. Li J, Yang J, Huang X, Zhang K-Q. Purification and characterization of an extracellular serine protease from Clonostachys rosea and its potential as a pathogenic factor. Process Biochem. 2006 4//;41(4):925-9.

126. Li F, Yang L, Lv X, Liu D, Xia H, Chen S. Purification and characterization of a novel extracellular alkaline protease from Cellulomonas bogoriensis. Protein Expr Purif. 2016 5//;121:125-32.

127. Salihi A, Asoodeh A, Aliabadian M. Production and biochemical characterization of an alkaline protease from Aspergillus oryzae $\mathrm{CH} 93$. Int $\mathrm{J}$ Biol Macromolec. 2016.

128. Lario LD, Chaud L, Almeida MdG, Converti A, Durães Sette L, Pessoa Jr A. Production, purification, and characterization of an extracellular acid protease from the marine Antarctic yeast Rhodotorula mucilaginosa L7. Fungal Biol. 2015 11//;119(11):1129-36.

129. Ferrareze PAG, Correa APF, Brandelli A. Purification and characterization of a keratinolytic protease produced by probiotic Bacillus subtilis. Biocatal Agric Biotechnol. 2016 7//;7:102-9.

130. Hajji M, Rebai A, Gharsallah N, Nasri M. Optimization of alkaline protease production by Aspergillus clavatus ES1 in Mirabilis jalapa tuber powder using statistical experimental design. Applied microbiology and biotechnology. 2008;79(6):915-23. 
131. Chu IM, Lee C, Li T-S. Production and degradation of alkaline protease in batch cultures of Bacillus subtilis ATCC 14416. Enzyme Microb Technol. 1992;14(9):755-61.

132. Patel R, Dodia M, Singh SP. Extracellular alkaline protease from a newly isolated haloalkaliphilic Bacillus sp.: Production and optimization. Process Biochem. 2005;40(11):3569-75.

133. Negi S, Banerjee R. Optimization of amylase and protease production from Aspergillus awamori in single bioreactor through EVOP factorial design technique. Food Technol Biotechnol. 2006;44(2):257-61.

134. Haddar A, Fakhfakh-Zouari N, Hmidet N, Frikha F, Nasri M, Kamoun AS. Lowcost fermentation medium for alkaline protease production by Bacillus mojavensis A21 using hulled grain of wheat and sardinella peptone. J Biosci Bioeng 2010;110(3):288-94.

135. Costa JM, Corbellini VA, Scroferneker ML. Study of different nitrogen sources on glucose uptake and production of melanin precursors and fungal mass of Fonsecaea pedrosoi cultured in tricyclazole. Process Biochem. 2004 1/30/;39(5):6336.

136. Adinarayana K, Ellaiah P. Response surface optimization of the critical medium components for the production of alkaline protease by a newly isolated Bacillus sp. J Pharm Pharm Sci. 2002;5(3):272-8.

137. Anandan D, Marmer WN, Dudley RL. Isolation, characterization and optimization of culture parameters for production of an alkaline protease isolated from Aspergillus tamarii. J ind microbiol biot. 2007;34(5):339-47.

138. Malathi S, Chakraborty R. Production of alkaline protease by a new Aspergillus flavus isolate under solid-substrate fermentation conditions for use as a depilation agent. Applied and environmental microbiology. 1991;57(3):712-6.

139. Vishwanatha KS, Appu Rao AG, Singh SA. Characterisation of acid protease expressed from Aspergillus oryzae MTCC 5341. Food Chem. 2009 5/15/;114(2):4027.

140. Fry S, Huang J, Milholland R. Isolation and preliminary characterization of extracellular proteases produced by strains of Xylella fastidiosa from grapevines. Phytopathology. 1994;84(4):357-63.

141. Drapeau GR, Boily Y, Houmard J. Purification and properties of an extracellular protease of Staphylococcus aureus. J Bio Chem. 1972;247(20):6720-6. 
142. Nam S-H, Walsh MK, Yang K-Y. Comparison of four purification methods to purify cysteine protease from Asian pear fruit (Pyrus pyrifolia). Biocatal Agric Biotechnol. 2016 1//;5:86-93.

143. Rojas JA, Cruz C, Mikan JF, Villalba LS, de García MCC, Restrepo S. Isoenzyme characterization of proteases and amylases and partial purification of proteases from filamentous fungi causing biodeterioration of industrial paper. Int Biodeterior Biodegradation. 2009;63(2):169-75.

144. Nascimento TP, Sales AE, Porto CS, Brandão RMP, de Campos-Takaki GM, Teixeira JAC, et al. Purification of a fibrinolytic protease from Mucor subtilissimus UCP 1262 by aqueous two-phase systems (PEG/sulfate). J Chromatogr B. 2016 7/1/;1025:16-24.

145. Yadav SK, Bisht D, Tiwari S, Darmwal Nandan S. Purification, biochemical characterization and performance evaluation of an alkaline serine protease from Aspergillus flavus MTCC 9952 mutant. Biocatal Agric Biotechnol. 2015 10//;4(4):66777.

146. Hernández-Martínez R, Gutiérrez-Sánchez G, Bergmann CW, Loera-Corral O, Rojo-Domínguez A, Huerta-Ochoa $S$, et al. Purification and characterization of a thermodynamic stable serine protease from Aspergillus fumigatus. Process Biochem. 2011 10//;46(10):2001-6.

147. Merheb CW, Cabral H, Gomes E, Da-Silva R. Partial characterization of protease from a thermophilic fungus, Thermoascus aurantiacus, and its hydrolytic activity on bovine casein. Food Chem. 2007;104(1):127-31.

148. Anwar A, Saleemuddin M. Alkaline-pH-actingdigestive enzymes of the polyphagous insect pest Spilosoma obliqua: stabilityand potential as detergent additives. Biotechnol Appl Biochem 1997;25(1):43-6. 